\title{
High endothelial venules (HEVs) in immunity, inflammation and cancer
}

\author{
Lucas Blanchard ${ }^{1}$. Jean-Philippe Girard ${ }^{1}$ (i)
}

Received: 29 March 2021 / Accepted: 19 April 2021 / Published online: 6 May 2021

(c) The Author(s) 2021

\begin{abstract}
High endothelial venules (HEVs) are specialized blood vessels mediating lymphocyte trafficking to lymph nodes (LNs) and other secondary lymphoid organs. By supporting high levels of lymphocyte extravasation from the blood, HEVs play an essential role in lymphocyte recirculation and immune surveillance for foreign invaders (bacterial and viral infections) and alterations in the body's own cells (neoantigens in cancer). The HEV network expands during inflammation in immunestimulated LNs and is profoundly remodeled in metastatic and tumor-draining LNs. HEV-like blood vessels expressing high levels of the HEV-specific sulfated MECA-79 antigens are induced in non-lymphoid tissues at sites of chronic inflammation in many human inflammatory and allergic diseases, including rheumatoid arthritis, Crohn's disease, allergic rhinitis and asthma. Such vessels are believed to contribute to the amplification and maintenance of chronic inflammation. MECA-79 tumor-associated HEVs (TA-HEVs) are frequently found in human tumors in $\mathrm{CD}^{+} \mathrm{T}$ cell-rich areas or $\mathrm{CD} 20^{+} \mathrm{B}$-cell rich tertiary lymphoid structures (TLSs). TA-HEVs have been proposed to play important roles in lymphocyte entry into tumors, a process essential for successful antitumor immunity and lymphocyte-mediated cancer immunotherapy with immune checkpoint inhibitors, vaccines or adoptive T cell therapy. In this review, we highlight the phenotype and function of HEVs in homeostatic, inflamed and tumor-draining lymph nodes, and those of HEV-like blood vessels in chronic inflammatory diseases. Furthermore, we discuss the role and regulation of TA-HEVs in human cancer and mouse tumor models.
\end{abstract}

Keywords High endothelial venules (HEVs) - Lymphocyte trafficking · Chronic inflammatory diseases · Cancer immunology $\cdot$ Tumor blood vessels $\cdot$ Tertiary lymphoid structures

\section{Introduction}

Endothelial cells play critical roles in physiology and physiopathology, and are involved in many important diseases, including cardiovascular diseases, chronic inflammatory diseases and cancer. Although all vascular endothelial cells share certain common functions, considerable structural and functional heterogeneity exists along the length of the vascular tree and in the microvascular beds of various organs. One of the most striking examples of organ-specific endothelial cell differentiation occurs at the level of high endothelial venules (HEVs), specialized post-capillary venules found in lymph nodes (LNs) and other secondary lymphoid organs

Jean-Philippe Girard

Jean-Philippe.Girard@ipbs.fr

1 Institut de Pharmacologie et de Biologie Structurale, IPBS, Université de Toulouse, CNRS, UPS, Toulouse, France
(Fig. 1) which mediate high levels of lymphocyte extravasation from the blood [1-6].

The most obvious characteristic of HEV endothelial cells (HECs) revealed by light-microscopic examination is their morphology. HECs have a plump, almost cuboidal appearance very different from the flat appearance of endothelial cells that line other vessels. This cuboidal appearance provides the basis for the name of high endothelium. Thome first noted the plump morphology of HECs in LNs in 1898 [10]. Thome wrote that, "at first notice, one is more inclined to think of the duct of a gland rather than that of a blood vessel". A few months later, in 1899, von Schumacher confirmed the observations of Thome and noted the presence of numerous lymphocytes within HEV walls [11]. However, the direction and physiological significance of lymphocyte migration through HEVs remained unappreciated during many decades. In two landmark studies published in 1964, Gowans et al. showed that radioactively labeled lymphocytes injected intravenously migrated rapidly into rodent LNs by 

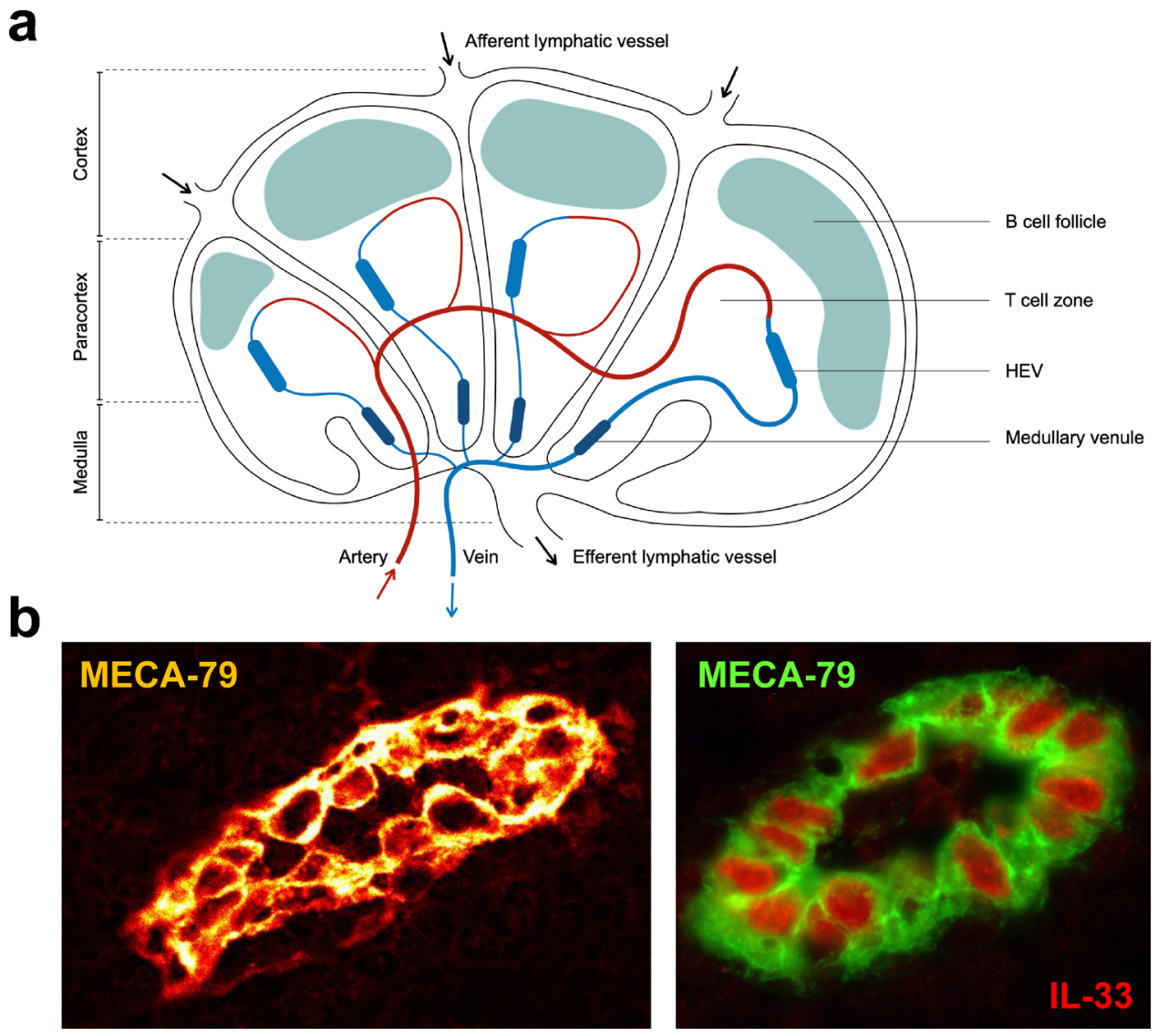

Fig. 1 HEVs in secondary lymphoid organs. a Lymph nodes are encapsulated lymphoid organs subdivided into three regions: the cortex, the paracortex and the medulla. Blood enters the LN through a main feeding artery that branches into arterioles and capillaries in the medulla and the paracortex, respectively. Then, blood flows from the capillary beds into the post-capillary HEVs that are located in the T cell zone of the LN. Finally, blood flows through medullary venules and leave the $\mathrm{LN}$ via a collecting vein. Immune cells enter the LN

crossing HEV walls $[12,13]$. Gowans concluded that HEVs are the site of a large-scale migration of lymphocytes from the blood into secondary lymphoid organs. Indeed, HEVmediated recruitment of lymphocytes is a very efficient process. It is estimated that as many as $5 \times 10^{6}$ lymphocytes migrate through the HEVs of the human body every second [2].

HEVs are present in all secondary lymphoid organs with the exception of spleen, including hundreds of LNs dispersed in the body, tonsils, adenoids, Peyer's patches in the small intestine, appendix, and small aggregates of lymphoid tissue associated with the mucosal surfaces of the respiratory, gastrointestinal and urogenital tract. HECs range from 7 to $10 \mu \mathrm{m}$ in width and 5-7 $\mu \mathrm{m}$ in height and are much less regular in outline than the term cuboidal would suggest. They exhibit great deformability and irregularity of shape [14]. The increased height of HECs might permit them to close about lymphocytes migrating through through HEVs or afferent lymphatic vessels and exit via the efferent lymphatic vessel in the medulla. b HEVs in human tonsils. MECA-79 staining reveals the "plump" cuboidal morphology of HEV endothelial cells (HECs) (Left). MECA-79 ${ }^{+}$HECs express high levels of the nuclear cytokine IL-33 [7] (Right). The gene encoding IL-33 was originally discovered as a gene highly expressed in MECA- $79^{+}$HECs isolated from human tonsils, and IL-33 was thus initially designated as "nuclear factor from high endothelial venules" (NF-HEV) $[8,9]$

intercellular spaces, thus allowing lymphocytes to cross the endothelium like "ships in canal locks" with minimal vascular leakage [15]. Although the most striking feature of HECs is their unusual height, ultrastructural analysis revealed additional features generally not observed in endothelial cells from other vessels. At the ultrastructural level, HECs exhibit the characteristics of metabolically active secretory-type cells, with a prominent Golgi complex, abundant mitochondria closely associated with rough endoplasmic reticulum, many ribosomes frequently found in polyribosome clusters, and a large rounded nucleus with one or two nucleoli $[14,16]$. The Golgi is particularly developed in areas where lymphocyte crossing is intense and often oriented towards the transmigrating lymphocytes [17]. HEV ligands for L-selectin, the major lymphocyte homing receptor, pass through the Golgi apparatus during their biosynthesis and become reactive to L-selectin in large Trans-Golgi-Network-associated vesicles [18]. After 
crossing the Golgi, these L-selectin ligands "en route" to the HEV lumen are present in cytoplasmic vesicles, likely to represent secretory vesicles. Another remarkable feature of HECs revealed by ultrastructural studies is the thick carbohydrate-rich glycocalyx that coats their luminal surface and represents the true interface with circulating lymphocytes $[2,16,19]$. Direct measurements showed that the thickness of the glycocalyx varied from $490 \pm 12$ in capillaries to $1280 \pm 108 \AA$ in HEVs [16]. This feature of the HEV glycocalyx is noteworthy in view of the evidence that sulfated carbohydrates and glycoproteins serve as essential recognition determinants for lymphocyte L-selectin [6]. In addition, the HEV glycocalyx may also facilitate the retention (immobilization) of secreted molecules on the luminal surface of HEVs [2, 14]. Indeed, immobilization of chemokines by heparan sulfate is important for HEVmediated lymphocyte entry into LNs [20, 21].

Evidence accumulated over the past 40 years indicates that blood vessels with HEV features develop in non-lymphoid tissues in many human chronic inflammatory diseases [2, 6, 22]. During the 1980s, Freemont and Ziff visualized the presence of HEV-like blood vessels in areas of lymphocyte aggregation in the inflamed synovium of patients suffering from rheumatoid arthritis (RA) [23, 24]. Such vessels distinguished by the plump morphology of their endothelial cells, and the presence of numerous lymphocytes within their walls, were not present in normal synovium. In their pioneering studies, Freemont and Ziff observed a strong correlation between the "plumpness" of endothelial cells lining HEV-like blood vessels and the number and percentage of perivascular lymphocytes [23, 24]. Jalkanen, Butcher, and Freemont demonstrated the capacity of HEV-like blood vessels to support lymphocyte adhesion in frozen sections of the inflamed synovium in vitro and to incorporate large amounts of radioactive sulfate, a unique metabolic property shared with lymph node HEVs [25, 26]. Together, these observations suggested that lymphocytes emigrated through HEVlike blood vessels to enter the inflamed synovium during RA. Freemont extended his observations to many other human chronic inflammatory diseases [27]. He showed that HEV-like blood vessels with cuboidal endothelium, that mediated sulfate uptake and lymphocyte adhesion in vitro, were present in areas of lymphocyte infiltration ( $>150$ lymphocytes $/ \mathrm{mm}^{2}$ ) in many tissues and disease states [22]. Freemont made several important observations: HEV-like blood vessels developed in sites that did not contain such vessels under normal conditions; lymphocyte infiltration always preceded the development of these vessels; plump endothelial cells did not show mitotic activity. Based on these observations, he concluded that HEV-like blood vessels develop from existing vessels following lymphocyte infiltration, and once developed, participate in a positive feedback loop increasing lymphocyte extravasation into the diseased tissues, thus contributing to the amplification and maintenance of chronic inflammation [22].

Ten years ago, we reported that blood vessels with HEV characteristics are frequently found in the stroma of many human solid tumors including melanomas, breast, ovarian, colon and lung carcinomas [28, 29]. These findings extended initial observations made by Freemont in the 1980 's [30]. In both breast tumors $(n=273)$ and primary melanomas $(n=225)$, the density of tumor-associated HEVs (TA-HEVs) was highly correlated with the density of $\mathrm{CD}^{+}$ $\mathrm{T}$ cells (including $\mathrm{CD} 8^{+}$cytotoxic $\mathrm{T}$ cells) and $\mathrm{CD} 20^{+} \mathrm{B}$ cells, indicating that TA-HEVs may function as major portals of entry for lymphocytes into human solid tumors [28, 29]. Interestingly, a high density of TA-HEVs in the tumor microenvironment significantly correlated with longer survival of breast cancer patients [28]. Blood vessels and tumor angiogenesis promote tumor growth and are generally associated with unfavorable clinical outcome. Therefore, these studies introduced the concept that "the phenotype of tumor blood vessels is important and that some subsets of tumor blood vessels (i.e. TA-HEVs) can contribute to tumor suppression rather than tumor growth" [28]. Studies in other human tumor types and murine tumor models confirmed these initial observations in primary breast cancer and melanoma (see below). Together, the findings suggested that TA-HEVs represent attractive targets for cancer diagnosis and treatment, and that novel therapeutic strategies based on the modulation of TA-HEVs could have a major impact on antitumor immunity and clinical outcome of cancer patients.

There are comprehensive reviews about the role of HEVs in LNs and other secondary lymphoid organs, to which the reader is referred [1-6]. In our previous article, we reviewed the phenotype and function of HEVs in LNs at steady state [1]. In the present review, we highlight the role and regulation of HEVs in homeostatic, inflamed and tumor-draining LNs, and those of HEV-like blood vessels in chronically inflamed tissues, and TA-HEVs in human and mouse tumors.

\section{High endothelial venules and lymphocyte trafficking in lymph nodes}

\section{MECA-79 ${ }^{+}$HEVs in homeostatic lymph nodes (LNs)}

In mammals, HEV s are present not only in LNs and other secondary lymphoid organs [1-6] but also in unconventional lymphoid tissues such as nasopharyngeal-associated lymphoid tissue (NALT) [31-33], tear duct-associated lymphoid tissue (TALT) [34], intestinal isolated lymphoid follicles (ILF) [35], mediastinal fat-associated lymphoid clusters (FALC) [36], and omental milky spots [37, 38]. The precise phenotype and function of HEVs in these various lymphoid tissues go beyond the scope of this review. Butcher et al. 
previously highlighted differences between HEVs in peripheral LNs, mucosal LNs and Peyer's patches [3, 39, 40]. Since HEV biology has been mostly studied in peripheral LNs [1], we will focus our discussion in the following paragraphs on peripheral lymph node HEVs. Today, we have a good understanding of the molecular mechanisms regulating lymphocyte extravasation through HEVs, thanks to the major contributions of the groups of Rosen, Butcher, Von Andrian, Miyasaka, Fukuda, Cyster, Lowe and many others [1-6].

The first interaction between naive lymphocytes and HEVs is initiated by lymphocyte L-selectin (also known as $\mathrm{CD} 62 \mathrm{~L}$ ) that recognizes a family of sulfated mucin-like glycoproteins known as HEV sialomucins [1, 6]. Although not specific to HECs, these HEV sialomucins, which include CD34, podocalyxin, endomucin, nepmucin and glycosylation-dependent cell adhesion molecule 1 (GlyCAM-1, only present in rodents; pseudogene in humans), become effective L-selectin ligands when they are post-translationally modified by enzymes highly expressed in HECs. For instance, CD34 that is broadly expressed on endothelial cells along the vascular tree, as well as on hematopoietic progenitors, functions as an L-selectin counter-receptor only when appropriately decorated by HEC-specific sulfated, fucosylated and sialylated oligosaccharides [41, 42]. The critical carbohydrate determinant for L-selectin recognition, 6-sulfo sialyl Lewis ${ }^{\mathrm{X}}$ (sialic acid $\alpha 2-3 \mathrm{Gal} \beta 1-4$ (Fuc $\alpha 1-3$ (sulfo-6) GlcNAc $\beta 1-\mathrm{R})$, is abundantly produced in HEVs and is present on both $\mathrm{N}$-glycans and extended core 1 and $2 \mathrm{O}$-glycans decorating HEV sialomucins [6, 43-49]. The expression of high levels of the L-selectin-binding HEV-specific glycoforms of HEV sialomucins is undoubtedly one of the most important features of the HEV endothelium. Indeed, monoclonal antibodies (mAbs) that define the best HEV markers currently available are directed against HEV-specific oligosaccharides decorating HEV sialomucins [43-46, 50]. For instance, the HEV-specific mAb "Mouse Endothelial Cell Antigen-79" (MECA-79), generated by Butcher et al. in 1988 [50], specifically recognizes 6-sulfo sialyl Lewis ${ }^{X}$ structures on extended core $1 O$-glycans [45]. The MECA-79 epitope is often designated peripheral lymph node addressin (PNAd) [50, 51]. However, it is important to mention that MECA-79 reacts not only with peripheral LN HEVs, but also with mucosal LN HEVs, Peyer's patches HEVs and HEV-like blood vessels in non-lymphoid tissues. Therefore, although the term PNAd is widely used to designate MECA79 reactive antigens in both lymphoid and non-lymphoid organs, MECA- $79^{+}$antigens and MECA- $79^{+}$blood vessels may be more appropriate designations than PNAd outside of peripheral LNs. MECA-79 is a fantastic tool for HEV studies. It is a very robust $\mathrm{mAb}$ for immunohistochemistry and immunofluorescence studies, which reacts specifically with HEVs in both humans and mice (no cross-reaction with other blood vessels in the body), and in both lymphoid and non-lymphoid organs $[50,51]$. Importantly, this is a function-blocking $\mathrm{mAb}$ that inhibits interactions of lymphocytes with HEVs in vitro and in vivo [50,52].

Crucial insights about the HEV phenotype came from genome-wide transcriptomic analyses of HECs from mouse peripheral LNs $[40,53,54]$ that extended pioneering studies of isolated human and mouse MECA-79 ${ }^{+}$HECs by differential expression and subtractive hybridization strategies [55-58]. MECA-79 ${ }^{+}$HECs displayed a unique transcriptional program clearly distinct from that of all other endothelial cell subsets in the LN [40, 53, 54]. Single-cell RNA sequencing (scRNA-seq) revealed that genes encoding HEV sialomucin GlyCAM-1 (Glycam1), CC-chemokine ligand 21 (CCL21; Ccl21a), and critical HEV enzymes (sulfotransferases: Chst4, Chst2; glycosyltransferases: Fut7, Gcnt1, B3gnt3, St3gal6) [45, 47-49, 59, 60], were among the top genes differentially and highly expressed in HECs [53]. In contrast, genes encoding other HEV sialomucins $(C d 34$, $E m c n, . .$.$) , were not differentially expressed in HECs. These$ transcriptomic analyses confirmed that the unique capacity of HECs to capture large numbers of lymphocytes is based on the coordinated expression of the different enzymes involved in the decoration of HEV sialomucins with high affinity 6-sulfo sialyl Lewis ${ }^{\mathrm{X}}$ L-selectin ligands [40, 53]. Transcriptional analysis also confirmed high expression in HECs of several genes implicated in HEV function (Enpp2, Spns2, Sphk1) that were previously or subsequently identified through in vivo studies in mice [61-65]. Another striking feature of HECs revealed by scRNA-seq is their cellular heterogeneity in homeostatic LNs [53]. Indeed, the two most abundant HEV genes in mouse peripheral LNs, Glycam 1 and $C c 121 a$ exhibit differential expression in HECs. In a subset of HEVs, some MECA- $79^{+}$HECs expressed high levels of Glycaml (or Ccl21a) mRNAs, although adjacent cells expressed none [53]. We also observed spatial heterogeneity of HEVs. MECA-79 ${ }^{+}$HECs in the LN paracortex had higher expression levels of GlyCAM-1 protein than MECA-79 ${ }^{+}$HECs located close to the medulla. The functional consequences of this HEC heterogeneity are currently unknown, but it reveals the highly plastic nature of the HEV phenotype. The spatial localization of HECs within the LN microenvironment might dictate accessibility to factors regulating HEV gene and protein expression and thereby contribute to the remarkable heterogeneity of HECs at steady state.

\section{HEV-mediated entry of lymphocytes in lymph nodes}

In homeostatic LNs, HEVs almost exclusively recruit naive and central memory lymphocytes [1]. Migration of naive $\mathrm{T}$ and $\mathrm{B}$ cells through HEVs, which has been precisely described thanks to the intravital microscopy technique set up by von Andrian in 1996 [52], occurs via a multistep adhesion cascade composed of rolling, firm arrest (sticking) and 
transmigration (Fig. 2a) [1, 52, 66]. Lymphocytes circulating in the blood first tether and roll on HEV walls through the binding of L-selectin to 6-sulfo sialyl $\mathrm{Le}^{\mathrm{X}}$ motifs decorating HEV sialomucins (Fig. 2b). This initial tethering interaction significantly reduces the velocity of lymphocytes, allowing them to interact with chemokines immobilized and presented on the luminal surface of HEVs by heparan sulfate [20,21]. Homeostatically expressed chemokines CCL21, CCL19, CXCL13 and to a lesser extent CXCL12, are pivotal factors during lymphocyte migration across HEVs because they mediate the activation of integrins essential for lymphocyte arrest in HEVs [67-71]. Indeed, while L-selectin is constitutively active, integrins require prior activation to recognize their ligands and subsequently mediate firm adhesion (sticking) to endothelial cells. Naive $\mathrm{T}$ cells express CC-chemokine receptor 7 (CCR7) and CXC-chemokine receptor 4 (CXCR4), the receptors for CCL21, CCL19 and CXCL12, whereas B cells express CXC-chemokine receptor 5 (CXCR5), the receptor for CXCL13, in addition to CXCR4 and CCR7 [72, 73]. Endothelium-presented chemokines are either produced by HEVs (such as CCL21 in mice but not in humans) or produced by neighboring stromal cells (fibroblastic reticular cells (FRCs) and follicular dendritic cells (FDCs)) and then transcytosed through HEVs [73-75].

The integrin lymphocyte function-associated antigen 1 (LFA1), which binds to intercellular adhesion molecule 1 and 2 (ICAM1 and ICAM2) expressed on endothelial cells, is the major integrin for $\mathrm{T}$ and $\mathrm{B}$ cell arrest in peripheral $\mathrm{LN}$ HEVs. In mesenteric LNs and other gut-associated lymphoid tissue (GALT), including Peyer's patches, the integrin $\alpha 4 \beta 7$, a major ligand of mucosal addressin cell adhesion molecule 1 (MAdCAM-1), is also critical for lymphocyte recruitment a

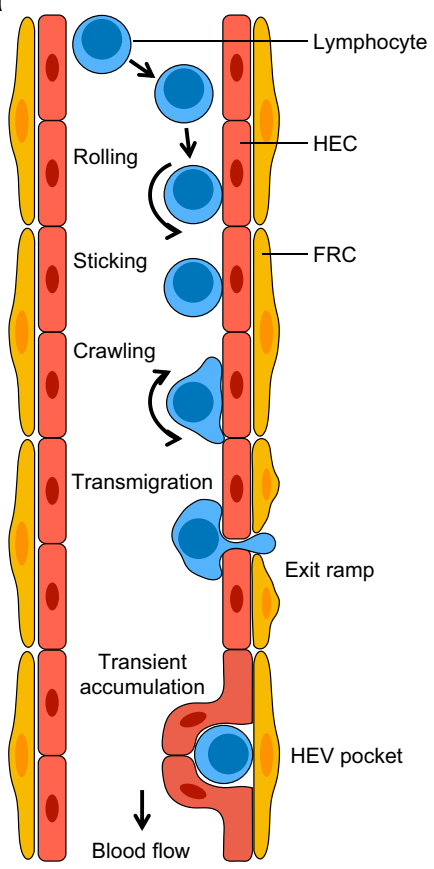

b

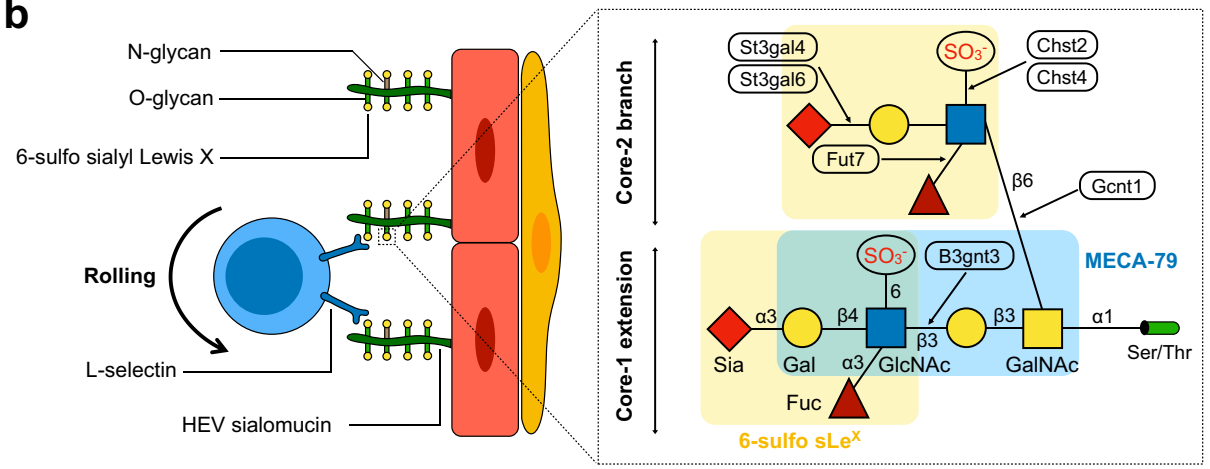

C

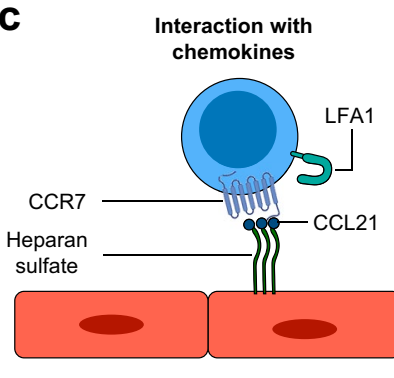

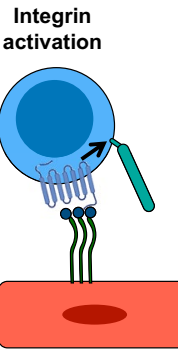

Firm arrest

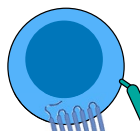

Fig. 2 HEV-mediated recruitment of lymphocytes in peripheral lymph nodes. a Naive $\mathrm{T}$ and $\mathrm{B}$ cells circulating in the blood tether and roll on HEV walls. Subsequently, rolling lymphocytes interact with chemokines immobilized on the HEV luminal surface. Chemokine receptor-dependent signaling induces activation of lymphocyte integrins that mediate firm binding (sticking) to their counter-receptors on HEV endothelium. Then, lymphocytes crawl on the HEV surface for a few minutes before transmigrating across the HEV endothelium via "exit ramps". Some lymphocytes also accumulate transiently in "HEV pockets". b Naive lymphocytes roll on HEV endothelium through the binding of L-selectin to 6-sulfo sialyl Lewis $\mathrm{X}$ motifs decorating both $\mathrm{O}$-glycans and $\mathrm{N}$-glycans on HEV sialomucins (Left). Representation of a bi-antennary O-linked glycan on a HEV sialomucin (Right). Both extended core-1 and core-2 branch structures can display the 6-sulfo sialyl Lewis $\mathrm{X}$ motif (highlighted in yellow). The 6-sulfo sialyl Lewis X motif is a tetra- saccharide composed of $N$-acetylglucosamine (GlcNAc), galactose (Gal), sialic acid (Sia) and fucose (Fuc), linked through $N$-acetylgalactosamine (GalNAc) to a serine (Ser) or threonine (Thr) residue of the core HEV sialomucin protein. $\alpha$ and $\beta$ linkages of the saccharide units are shown. The epitope of MECA-79 (highlighted in blue) is a component of the core- 1 extension. The C-6 sulfation (red SO3-) of $\mathrm{N}$-acetylglucosamine, that is referred to as "6-sulfo", is required for both L-selectin and MECA-79 recognition. Black rectangles indicate genes encoding enzymes involved in the synthesis of the 6-sulfo sialyl Lewis X motif. c Naive lymphocytes rolling on HEV walls interact with chemokines that are presented by heparan sulfate such as CCL21. Signaling through CCR7 induces conformational changes in the lymphocyte integrin LFA1, which mediate binding to ICAM1 and ICAM2 on the HEV endothelium, leading to firm arrest (sticking) of the lymphocytes. Following a rapid step of crawling, lymphocytes eventually transmigrate through HEVs to enter the lymphoid tissue 
through HEVs $[6,76]$. The combination of shear forces of the blood flow and $\mathrm{G}$ protein-coupled chemokine receptor signaling induces conformational changes in LFA1 molecules, leading to firm adhesion of lymphocytes to ICAM1 and ICAM2 expressed on HECs (Fig. 2c) [68, 70, 77]. Following stable arrest, lymphocytes can be observed crawling along the luminal surface of HEVs, looking for appropriate transmigration sites [78]. When they finally find an exit site, lymphocytes rapidly cross the endothelial barrier via paracellular (between adjacent endothelial cells) or transcellular (through the cytoplasm of endothelial cells) migration even if the paracellular migration route seems to be largely favored [79-83]. Remarkably, lymphocytes tend to follow each other through discrete hot spots that are called "exit ramps" when transmigrating through HEVs [78]. However, crawling lymphocytes can also transiently accumulate in endothelial structures called HEV pockets before entering the LN parenchyma [83, 84]. These "waiting areas" could be instrumental in homeostatic LNs to maintain a constant steady-state cellularity while supporting extensive lymphocyte trafficking. In addition to the mechanisms described above, other adhesion molecules implicated in lymphocyte trans-endothelial migration exist. For additional information, readers are referred to "state-of-the-art" reviews on leukocyte transmigration $[85,86]$.

\section{Mechanisms regulating the phenotype and function of HEVs in lymph nodes}

Pioneering studies performed more than 30 years ago revealed that $\mathrm{LN}$ afferent lymphatic vessel ligation results in HEV dedifferentiation [87]. This process, which involves HEV morphology "flattening", downregulation of MECA79 antigens and reduced ability to support lymphocyte adhesion, is fully revertible following interruption of ligation [88-90]. Interestingly, subsequent studies demonstrated that lymph-borne molecules such as chemokines can reach HEVs through a stromal conduit system composed of FRCs, revealing a special connection between HEVs and the lymph coming from drained tissues [75, 91, 92]. Together with phenotypic analyses showing that freshly purified human HECs rapidly lose the specialized HEV phenotype when cultured ex vivo [93], these results indicated that HEVs exhibit a remarkable plasticity and are highly dependent on the lymphoid microenvironment and lymph-derived cells and/or factors.

Eventually, we discovered that $\mathrm{CD} 11 \mathrm{c}^{+}$dendritic cells (DCs) are critical for maintenance of HEV phenotype and function in homeostatic LNs [94]. Indeed, in vivo depletion of $\mathrm{CD} 11 \mathrm{c}^{+} \mathrm{DCs}$ induces a reversion to an immature HEV phenotype characterized by reduced expression of MECA79 antigens, downregulation of HEV-specific genes (Chst4, Fut7, Glycam I) and upregulation of the mucosal addressin
MAdCAM-1, a marker of immature HEVs in neonatal peripheral LNs [95]. The functional consequence of this altered HEV phenotype is a profound defect in lymphocyte recruitment to LNs that culminates in LN hypocellularity. Additional studies confirmed the pivotal role of DCs in HEV-mediated lymphocyte homing to LNs [96, 97]. Interestingly, it has also been shown that DCs contribute to HEV growth in a vascular endothelial growth factor (VEGF)dependent fashion, which confers additional regulating properties to DCs [96, 98].

The lymphotoxin- $\beta$ receptor (LT $\beta R$ ) and downstream non-canonical nuclear factor $\mathrm{kB}(\mathrm{NF}-\mathrm{kB})$ signaling pathway are essential for HEV maintenance and lymphocyte homing to adult LNs [99-102]. Endothelial cell-specific deletion of LT $\beta$ R and treatment with LT $\beta$ R-immunoglobulin (Ig) soluble decoy receptor indicate that continuous triggering of LT $\beta R$ on HECs is critical for the expression of several genes related to HEV biology (Glycam1, Fut7, Chst4, Gcnt1), demonstrating that many HEV-specific genes are LT $\beta$ Rdependent genes [53, 99, 102, 103]. scRNA-seq analyses after treatment with LT $\beta$ R-Ig revealed that Chst 4 requires lower levels of LT $\beta$ R-dependent signals for expression than the other HEV genes (Glycam1, Fut7, Gcnt1) [53]. LT $\beta$ R stimulation results in activation of both canonical and noncanonical NF-kB signaling pathway whereas tumor necrosis factor receptor 1 (TNFR1) engagement mediates canonical NF-kB signaling only [104]. Neither the phenotype of HEVs nor the expression of HEV-specific genes are affected in TNFR1-deficient mice and mice treated with TNFR-Ig [99, 101]. On the contrary, LN HEVs from mice deficient in components of the non-canonical NF-kB signaling pathway have reduced expression of MECA-79 antigens, GlyCAM-1 and GlcNAc6ST-2 (Chst4), showing that LT $\beta$ R ability to induce the non-canonical NF-kB signaling pathway is essential for the regulation of HEVs $[100,101]$.

In fact, we demonstrated that $\mathrm{CD} 11 \mathrm{c}^{+} \mathrm{DC}$ are a major source of LT $\beta$ R ligands, lymphotoxin $\alpha$ (LT $\alpha)$, lymphotoxin $\beta$ (LT $\beta$ ) and LIGHT, and that DC-derived lymphotoxin is critical for HEV-mediated lymphocyte recruitment to homeostatic LNs [94]. Because intranodal DCs are positioned close to HEVs both at steady-state and during inflammation [105-107], we proposed a model in which DCs regulate HEV phenotype and function through direct stimulation of LT $\beta R$ [1]. Future studies will be required to identify the precise DC subsets involved in the process although LNresident conventional $\mathrm{DC} 1$ and 2 ( $\mathrm{CDC} 1$ and $\mathrm{CDC} 2$ ) appear as obvious candidates because of their frequent association with HEVs [107].

\section{HEVs in inflamed lymph nodes}

LNs can be regarded as immune hubs strategically positioned in the organism to provide regional immune surveillance 
[108]. These highly specialized organs orchestrate the initiation and the maintenance of adaptive immune responses during infection and cancer. Following immune challenge, the LN draining inflamed tissues is the site of an important stromal remodeling enabling its increase in size and cellularity $[109,110]$. Within the inflamed LN, the number but also the phenotype of HEVs are modified to support the ongoing immune response (Fig. 3) [53, 98, 103, 111, 112].

Soon after the initial inflammatory stimulus, the LN blood vasculature undergoes substantial enlargement and remodeling which includes expansion of the primary feed arterioles and HEV network, a process that is thought to increase influx of lymphocytes and therefore the efficiency of screening for rare antigen-specific lymphocytes [112-114]. Mechanistically, it has been shown in models of multicolor fate mapping that LN blood vascular growth relies on the clonal proliferation of some HECs that act as local progenitors to create both capillaries and HEV neovessels [112]. More recently, scRNA-seq studies of mouse LN endothelial cells identified a population of progenitorlike activated capillary endothelial cells, defined as capillary resident precursors (CRPs), that are actively mobilized for
LN angiogenesis after immunization [54]. Among LN BECs, CRPs selectively express Apln and can be observed by staining for the human estrogen receptor (ER), which serves as a surrogate for Apln expression. At steady state, $\mathrm{ER}^{+}$endothelial cells are present in capillaries whereas HECs do not express the receptor. However, Apln-reporter mice revealed that many HECs and capillary endothelial cells are positive for the reporter three weeks after an immune challenge, showing that Alpln-expressing CRPs can also contribute to inflammation-induced HEV neogenesis, in addition to HECs themselves [112].

DC mobilization increases during the initial phase of LN swelling [115]. DC accumulation in the inflamed LN could be the initial trigger for blood vasculature enlargement as DCs have been shown to control proliferation of endothelial cells (including HECs) in LNs [98, 116], although B and $\mathrm{T}$ cells may participate too [117-119]. In both instances, LT $\beta$ R ligands and VEGF-A are the critical mediators of LN vasculature remodeling. At later stages, afferent lymphatic function is transiently diminished, likely causing dilution of DCs in the LN microenvironment [103]. Concurrently to this afferent lymph flow shutdown, HECs acquire an inflamed

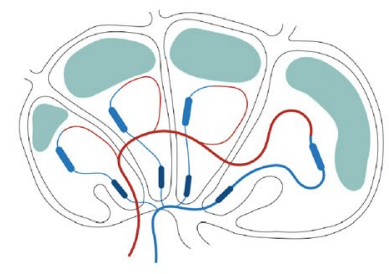

STEADY-STATE

Homeostatic HECs

MECA-79++++

CCL21 $1^{++++}$

GlyCAM $1^{++++}$

$\mathrm{FUT7}^{+++}$

MAdCAM-1

$\mathrm{CD}^{2} \mathrm{P}^{+}$

CD62E-

CXCL9

Recruitment of naive lymphocytes

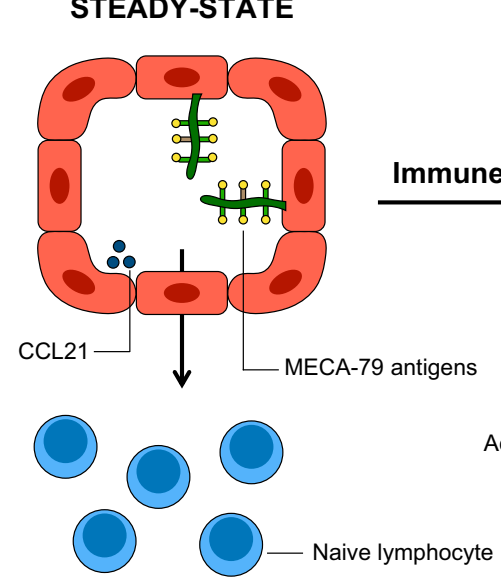

Fig. 3 HEVs in inflamed lymph nodes. During an immune challenge, the HEV network expands, contributing to the increase in size and cellularity of the reactive LN (Top). HECs in reactive LNs are phenotypically different from HECs in homeostatic LNs at steady state (Bottom). scRNA-seq analyses revealed the precise phenotypes of homeostatic and inflamed LN HECs [53]. Several genes encoding

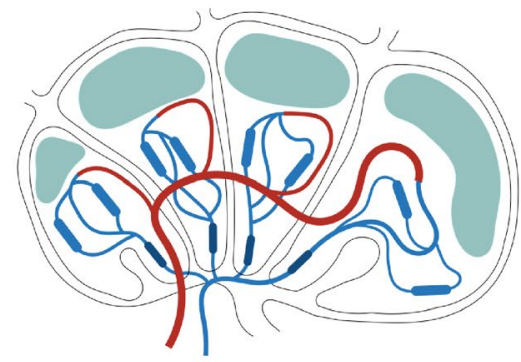

INFLAMMATION
Inflamed HECs MECA-79 ${ }^{++++}$ CCL2 $1^{+++}$ GlyCAM1+++ $\mathrm{FUT7}^{++}$ MAdCAM- $1^{+}$ CD62P $\mathrm{P}^{+++}$ $\mathrm{CD}^{2} \mathrm{E}^{++}$ $\mathrm{CXCL}^{++}$

Recruitment of naive lymphocytes, activated lymphocytes and myeloid cells inflammatory proteins are upregulated (P- and E-selectins, CXCL9), resulting in the recruitment of novel immune cells such as activated lymphocytes and myeloid cells. Importantly, the recruitment of naïve lymphocytes in inflamed LNs is still efficient despite downregulation of mature HEV genes, probably because levels of MECA-79 antigens and chemokine CCL21 remain very high 
endothelial cell phenotype (Fig. 3) that is marked by temporary downregulation of mature HEV genes (Glycam1, Fut7, Gcnt1), maintenance of strong MECA-79 expression, and upregulation of inflammatory proteins (P-selectin, E-selectin and CXCL9) and immature HEV marker MAdCAM-1 [53, 103, 120-123]. As a consequence of this phenotypic switch, novel immune cell populations such as neutrophils and activated effector/effector memory $\mathrm{T}$ cells are recruited through inflamed HEVs [121, 122, 124-127]. Importantly, the ability of inflamed HEVs to mediate L-selectin-dependent naive lymphocyte recruitment is not compromised despite downregulation of mature HEV genes [53, 120]. Interestingly, recent work from the Butcher's lab revealed that non-HEV medullary post-capillary venules could also be involved in myeloid cell homing to inflamed LNs via an L-selectin-independent mechanism, unveiling the existence of local venular specializations for the recruitment of specific immune cell populations during acute inflammation of the $\mathrm{LN}$ [54].

\section{HEVs in tumor-draining lymph nodes}

The tumor-draining lymph node (tdLN), which is the first regional lymph node draining established tumors, is considered as the major activation site of tumor-specific lymphocytes [128]. The TdLN is not only important for the initiation of T-cell-dependent antitumor responses, but also for response to various cancer treatments, including radiotherapy and immune checkpoint blockade $[129,130]$. However, as a sentinel LN, the tdLN is also a privileged site for cancer cell metastasis, revealing its dual role in cancer $[131,132]$.

Because they mediate naive lymphocyte entry to tdLNs, HEVs indirectly participate to the priming of naive lymphocytes specific for cancer antigens and are consequently crucial components of T-cell-dependent antitumor responses. In fact, HEV-mediated homing of naive lymphocytes to tdLNs is even targeted by the primary tumor which reduces expression of CCL21 on HEVs, thereby reducing lymphocyte adhesion to the endothelium [133]. This process is a striking illustration of the capacity of the primary tumor to drive HEV reprogramming in the tdLN [132]. Indeed, several reports in mouse models and human patients indicate that tdLN HEVs exhibit extensive phenotypical and morphological changes during tumor progression, including vessel dilatation, thinning of HEC morphology and discontinuous expression of MECA-79 antigens [134-138]. TdLN HEV remodeling occurs before the apparition of nodal metastases, suggesting that it is part of a pre-metastatic niche establishment program induced by the primary tumor [134-136]. Nevertheless, the density of abnormal HEVs is significantly higher in patients with established metastases in their LNs, showing that HEV identity and function might by highly compromised in metastatic LNs [135]. In some instances, the level of HEV remodeling in the tdLN correlated with disease progression and clinical outcome $[135,136]$. For instance, abnormal HEVs with red blood cells observed in their lumen, which is a feature of HEVs with altered vascular integrity [139], have been associated with a worse prognosis in squamous cell carcinoma [135].

The participation of the tdLN in the dissemination of cancer cells to distant organs is a widely accepted hypothesis [131]. Efferent lymphatics and subsequent passage through thoracic duct is the major dissemination route for cancer cells, but the ability of abnormal HEVs to provide extralymphatic route of dissemination has also been questioned [140]. Two recent studies based on intralymphatic injection of high numbers of cancer cells in afferent lymphatics concluded that LN HEVs could constitute an effective exit route for cancer cell dissemination in the blood circulation [141, 142]. However, intralymphatic injection of non-physiologic numbers of cancer cells might not accurately mimic the metastatic processes observed in human patients, thus challenging the clinical relevance of these results. Moreover, whether incriminated HEVs are bona fide HEVs or profoundly abnormal venules that have lost their HEV function remains unclear. Metastasis is more likely to occur through de-differentiated HEVs that are no longer functional for lymphocyte recruitment.

\section{HEV-like blood vessels in chronic inflammatory diseases}

\section{MECA-79 ${ }^{+}$HEV-like blood vessels in chronically inflamed tissues}

Inflammation is an evolutionary conserved process characterized by the activation of immune and non-immune cells to protect the host from foreign invaders during tissue injury, infection and cancer [143]. Acute inflammation is a temporally restricted protective response that is rapidly resolved to limit excessive tissue damage. In contrast, chronic inflammation is a persistent and non-resolving response causing tissue destruction and loss of function with progressive clinical symptoms. Immune cell-induced reprogramming of stromal cells is an important feature of chronic inflammation and is thought to exacerbate inappropriate immune responses [144]. HEV-like blood vessels phenotypically similar to lymphoid tissue HEVs appear in many human inflammatory diseases affecting different anatomic sites (Table 1), including chronic inflammatory diseases such as RA (Fig. 4a) and inflammatory bowel diseases (Crohn's disease, ulcerative colitis), and allergic diseases such as asthma and allergic rhinitis [2, 6, 145-148]. Thus, development of HEV-like blood vessels is not disease- or organ-specific and might be a universal property of chronically inflamed tissues. 
Table 1 MECA-79+ HEV-like blood vessels in human inflammation

\begin{tabular}{|c|c|c|}
\hline Condition & Target organ & Associated features \\
\hline \multicolumn{3}{|l|}{ Allergic diseases } \\
\hline Bronchial asthma $[149,150]$ & Lung & Co-expression of sLex epitope HECA-452 \\
\hline Allergic rhinitis [151] & Nasal mucosa & \\
\hline Allergic contact dermatitis [51] & Skin & \\
\hline \multicolumn{3}{|l|}{ Chronic inflammatory diseases } \\
\hline Rheumatoid arthritis $[51,152-156]$ & Synovium & $\begin{array}{l}\text { Disappearance after anti-TNF } \alpha \text { treatment; Expression of Glc- } \\
\text { NAc6ST-2 (CHST4); Co-expression of sLex epitope HECA- } \\
\text { 452; Perivascular stromal cells producing CCL21; Presence } \\
\text { of TLSs in high-grade inflammatory lesions }\end{array}$ \\
\hline $\begin{array}{l}\text { Inflammatory bowel diseases (Crohn's disease, ulcerative } \\
\text { colitis) }[152,155,157-162]\end{array}$ & Gut & $\begin{array}{l}\text { Disappearance during remission in ulcerative colitis; Associ- } \\
\text { ated with } \mathrm{T}_{\mathrm{N}} \text { and } \mathrm{T}_{\mathrm{CM}} \text { infiltration } \\
\text { Preferentially associated with T cells, particularly CD4 }{ }^{+} \mathrm{T} \\
\text { cells; Co-expression of sLex epitope HECA-452; Perivascular } \\
\text { stromal cells producing CCL21; Presence of TLSs }\end{array}$ \\
\hline
\end{tabular}

Autoimmune thyroiditis (Hashimoto's disease, Graves' dis-
ease) $[51,157]$ Arthritis [163]

Spondyloarthritis [164]

Inflammatory skin diseases (psoriasis, lichen planus, cutaneous lymphoid hyperplasia, cutaneous lupus erythematosus) [51, 157, 165, 166]

Conjunctival inflammation [167]

Chronic rhinosinusitis [168, 169]

Sjögren's syndrome $[155,170,171]$

Lichen planus [165]

Type I autoimmune pancreatitis [172]

Inflammatory myopathies [173]

Bronchiectasis [174]

Idiopathic pulmonary arterial hypertension [175]

Glomerulonephritis [176]

Infection

Chronic Helicobacter pylori gastritis [235-237]

Organ transplant rejection

Acute heart allograft rejection [177, 178]

Acute kidney allograft rejection [179, 180]

Obliterative bronchiolitis after lung transplantation [181]

Hyperplasia and benign neoplasms

Warthin's tumor [182]

Benign prostatic hyperplasia [183]

Cutaneous pseudolymphomas [184]

Pregnancy

Pregnant uterus [185]
Thyroid

Synovium

Skeleton

Skin

Conjunctiva

Nasal and

paranasal mucosa

Salivary glands Perivascular stromal cells producing CCL21; Presence of TLSs

Oral mucosa

Pancreas

Muscle Presence of TLSs

Lung

Lung

Kidney

Stomach

Heart

Kidney

Lung

Salivary gland Preferentially associated with T cells

Prostate

Skin

Decidua

Disappearance after anti-IL-17A treatment (Secukinimab)

Lymphoid infiltrates but not organized in TLSs; Co-expression of sLex epitope HECA-452

Not reduced after hydrocortisone treatment

Associated with severity of inflammation

Preferentially associated with T cells, particularly CD4+ T cells

Presence of TLSs

Associated with progression of inflammation; Disappearance after eradication of $H$. pylori

Associated with severity of graft rejection; Co-expression of sLex epitope HECA-452; Presence of TLSs

Co-expression of sLex epitope HECA-452; Presence of TLSs

Preferentially associated with $\mathrm{T}$ cells, particularly $\mathrm{CD} 4^{+} \mathrm{T}$ cells; Associated with severity of inflammation and lower urinary tract symptoms

Reduced density of MECA-79+ ${ }^{+}$HEV-like blood vessels is associated with idiopathic recurrent pregnancy losses

HECA-452 mAb recognizing non-sulfated sLex, $T_{C M}$ central memory $\mathrm{T}$ cells, $T_{N}$ naive $\mathrm{T}$ cells, $T L S s$ B cell-rich tertiary lymphoid structures 
a

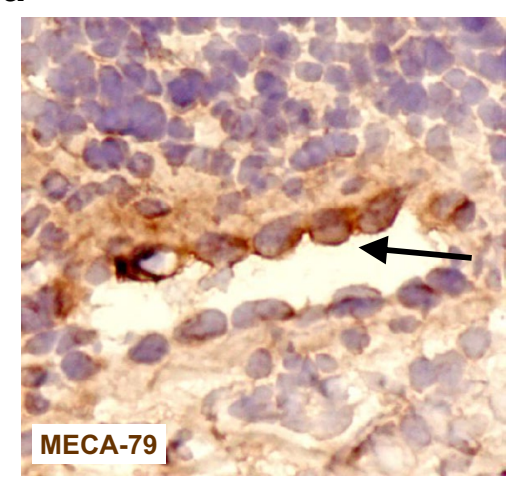

b

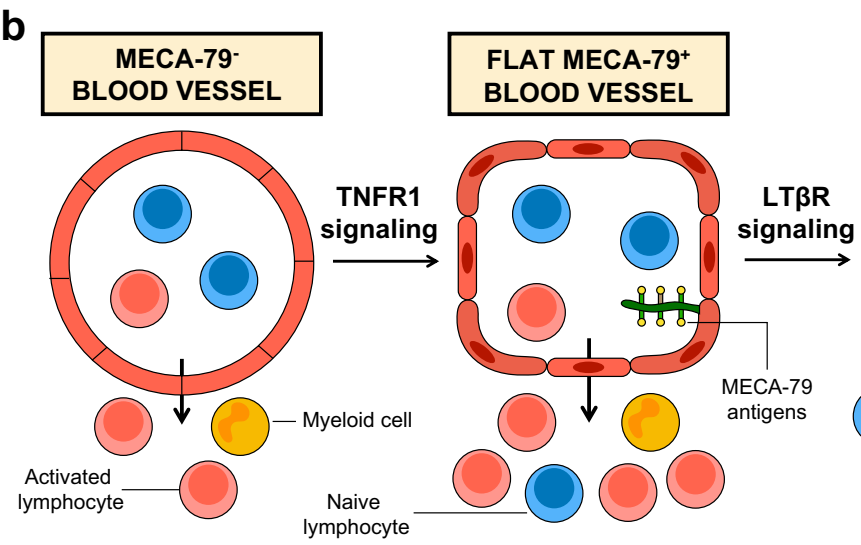

MECA-79+ HEV-LIKE BLOOD VESSEL
Fig. 4 HEV-like blood vessels in chronic inflammation. a A MECA$79^{+}$HEV-like blood vessel in the inflamed synovium from a patient suffering from RA. Endothelial cells exhibit a "plump" cuboidal morphology. Staining with MECA-79 is more intense on the side of the vessel in contact with the immune infiltrate (arrow). b During acute inflammation, MECA-79- blood vessels are able to recruit activated lymphocytes and myeloid cells (Left). Prolonged inflammatory signals (such as LT $\alpha 3$ ) trigger TNFR1 signaling that induces expression

The HEV-specific mAb MECA-79 recognizes HEVs from lymphoid tissues, but also HEV-like blood vessels from extra-lymphoid tissues in both mice and humans, making it a very useful tool for the identification of ectopic HEVlike blood vessels. Indeed, systematic surveys involving large numbers of independent samples revealed that HEVlike blood vessels are recognized by MECA-79 in various human chronic inflammatory diseases affecting many different organs $[51,157]$. MECA-79 ${ }^{+}$HEV-like blood vessels express the post-capillary venule marker Duffy antigen receptor for chemokines (DARC) [186], similar to HEVs in lymphoid organs [56], suggesting that they likely arise from inflammation-induced reprogramming of pre-existing postcapillary venules [152]. HEV-like blood vessels also express the mucosal addressin MAdCAM-1 in GALT during inflammatory bowel diseases [187]. In many diseases, the intensity of MECA-79 staining correlated with the extent of mononuclear cell infiltration in inflamed lesions, which suggests that the level of expression of MECA-79 antigens might be a good indicator of the functional competence of HEV-like blood vessels. Interestingly, some flat-walled blood vessels are positive for MECA-79, indicating that MECA- $79^{+}$blood vessels encompass a wide range of venules with distinct degree of maturation regarding the HEV phenotype. Histological examinations of HEV-like blood vessels in human chronically inflamed tissues precludes definitive conclusions on their functionality and their ability to mediate lymphocyte recruitment. In contrast, mouse models of chronic inflammation, which recapitulate several features of human diseases including the development of HEV-like blood vessels, allow for in vivo functional investigations. A comprehensive list of MECA-79 antigens on post-capillary venules lined by flat endothelial cells, during the initial stages of chronic inflammation (Middle). Maintenance of chronic inflammation and subsequent activation of LT $\beta \mathrm{R}$ signaling induce additional maturation and acquisition of a fully mature HEV-like phenotype that is associated with increased luminal expression of MECA-79 antigens, cuboidal morphology and enhanced recruitment of naive lymphocytes (Right)

of mouse inflammatory conditions in which MECA-79 ${ }^{+}$ HEV-like blood vessels develop is included in Table 2. AKR mice develop hyperplastic thymus containing MECA-79 ${ }^{+}$ HEV-like blood vessels in close association with $\mathrm{T}$ and $\mathrm{B}$ cells, before the onset of T cell lymphoma [188]. Short-term in vivo homing assays showed that MECA-79 ${ }^{+} \mathrm{HEV}$-like blood vessels are involved in lymphocyte trafficking to the hyperplastic thymus. Indeed, injection of blocking amounts of MECA-79 or anti-L-selectin mAb MEL-14 abolished the recruitment of adoptively transferred lymphocytes, revealing the functional significance of MECA-79 expression on HEV-like blood vessels [188]. Similar findings were obtained in the inflamed lacrimal glands of NOD mice, a model for autoimmune-mediated insulin-dependent diabetes mellitus (IDDM) in which ectopic lymphoid infiltrates containing MECA- $79^{+}$HEV-like blood vessels are observed in several tissues [189]. After seven months of life, NOD mice also develop bronchus-associated lymphoid tissue (BALT) in the lung. Interestingly, treatment with MECA-79 and MEL-14 antibodies blocked the homing of adoptively transferred lymphocytes from blood into inflamed bronchopulmonary tissues [190]. These results obtained in three distinct inflamed tissues demonstrate first, that MECA- $79^{+}$HEV-like blood vessels are functional, and second, that the L-selectin-MECA-79 antigens axis is involved in lymphocyte trafficking to various chronically inflamed tissues. In contrast to MECA-79 antigens, MAdCAM-1 is not involved in the recruitment of adoptively transferred lymphocytes to the inflamed lacrimal glands and BALT of NOD mice [189, 190].

HEV-like blood vessels of chronically inflamed tissues can be observed close to diffuse non-organized lymphoid 
Table 2 MECA-79 ${ }^{+}$HEV-like blood vessels in mouse inflamed tissues

\begin{tabular}{lll}
\hline Condition & Target organ & Associated features \\
\hline
\end{tabular}

Models of chronic inflammation

Diabetes (NOD mice) [191-193]

Autoimmune sialoadenitis (NOD mice) [191, 192, 194]

Autoimmune dacryoadenitis (NOD mice) [189, 191, 195]

BALT (NOD mice) [190]

Thymic hyperplasia (AKR mice) [188, 191, 196]

Neonatal thymectomy-induced autoimmune gastritis [197]

Diabetes (H8 mice derived-DC injection in RIP-LCMV-GP mice) [198]

Collagen-induced arthritis [199]

Pristane-induced peritoneum inflammation [200]

Atherosclerosis (apoE ${ }^{-/-}$mice) [201]

LPS-induced iBALT [202]

Sialoadenitis (submandibular gland administration of AdV5) [203]

Bleomycin-induced lung fibrosis [36]

Lupus nephritis (NZB/W lupus-prone mice) [204]

Skin inflammation (intradermal injection of newborn lymph node-derived cells) [205]

Skin inflammation (subcutaneous injection of lymph nodederived stromal cell lines) [206]

Infection

Probionibacterium acnes-induced granulomatous liver disease [207]

Helicobacter-induced chronic hepatitis [208]

Helicobacter pylori-induced gastritis [209]

Influenza-induced iBALT [210, 211]

\section{Genetically modified mice}

Hyperplastic pancreatic islets (RIP1-Tag5 mice) [212]

Inflammed pancreatic islets (RIP-CCL19 mice) [213]

Inflammed pancreatic islets (RIP-CCL21, RIP-CCL21a and

RIP-CCL21b) [213-215]

Inflammed pancreatic islets (RIP-CXCL13) [191, 216]
Pancreas

Salivary gland

Co-expression of MAdCAM-1; Expression of the HEVrestricted sulfotransferase GlcNAc6ST-2 (Chst4)

Expression of the HEV-restricted sulfotransferase GlcNAc6ST-2 (Chst4); Reduced after LT $\beta R$-Ig treatment; Presence of TLSs

Lacrimal gland Expression of the HEV-restricted sulfotransferase GlcNAc6ST-2 (Chst4); MECA-79 and anti-CD62L block migration of adoptively transferred lymphocytes to inflamed lacrimal glands; Reduced after LT $\beta$ R-Ig treatment; Presence of TLSs

Lung

Thymus

MECA-79 and anti-CD62L block migration of adoptively transferred B and T lymphocytes to BALT; Presence of TLSs

Co-expression of MAdCAM-1; Expression of the HEVrestricted sulfotransferase GlcNAc6ST-2 (Chst4) and fucosyltransferase Fuc-T7 (Fut7); Associated with binding of L-selectin-IgM chimera; MECA-79 and anti-CD62L block migration of adoptively transferred lymphocytes to hyperplastic thymus

Gastric mucosa Presence of TLSs

Pancreas Presence of TLSs

Synovial tissue Expression of the HEV-restricted sulfotransferase GlcNAc6ST-2 (Chst4)

Peritoneum Presence of TLSs

Aorta

Lung

Salivary gland

Associated with migration of adoptively transferred lymphocytes; Reduced after LT $\beta R$-Ig treatment; Presence of TLSs

Present in $\mathrm{Rorc}^{-/-}$and Id2 ${ }^{-/-}$mice; Absent in $\mathrm{LT}^{-/-}$and DKO mice, and after LT $\beta$ R-Ig treatment; Presence of TLSs

Presence of TLSs

Lung Presence of TLSs

Kidney Presence of TLSs

Skin

Absent with $\mathrm{LT}^{-/-}$mice-derived cells; Presence of TLSs

Skin

Presence of TLSs

Liver

Presence of TLSs

Liver

Co-expression of MAdCAM-1; Expression of CCL21; Presence of TLSs

Gastric mucosa Presence of TLSs

Lung

Present in CXCL13 ${ }^{-/-}$mice; Reduced in plt/plt mice; Absent in $\mathrm{LT} \alpha^{-1-}$ mice; Presence of TLS

Pancreas

Pancreas

Presence of TLSs

Pancreas Present in Ikaros ${ }^{-/-}$mice but absent in Rag $1^{-/-}$mice, and reduced after LT $\beta$ R-Ig treatment; Presence of TLSs

Pancreas
Present in TNFR $1^{-/-}$mice but reduced in $\mu \mathrm{M}^{-/-}$and $\mathrm{LT}^{-/-}$ mice, and after LT $\beta$ R-Ig treatment; Expression of the HEVrestricted sulfotransferase GlcNAc6ST-2 (Chst4); Presence of TLSs 
Table 2 (continued)

\begin{tabular}{|c|c|c|}
\hline Condition & Target organ & Associated features \\
\hline Inflammed pancreatic islets (RIP-LT mice) $[217,218]$ & Pancreas & $\begin{array}{l}\text { Absent in Rag } 2^{-/-} \text {and } \mathrm{p} 55^{-/-} \text {(TNFR1) mice; Reduced infiltra- } \\
\text { tion of naive lymphocytes in LT } \beta^{-/-} \text {mice; Presence of TLSs }\end{array}$ \\
\hline Inflammed pancreatic islets (RIP-LT $\alpha \beta$ mice) [219] & Pancreas & $\begin{array}{l}\text { MECA-79 }{ }^{+} \text {HEV-like blood vessels with luminal expression } \\
\text { of MECA-79 antigens and expression of the HEV-restricted } \\
\text { sulfotransferase GlcNAc6ST-2 (Chst } 4) \text {; Present in LT } \beta^{-/-} \\
\text {mice; Presence of TLSs }\end{array}$ \\
\hline Autoimmune pancreatitis $(\operatorname{Tg}($ Ela1-LT $\alpha, \beta)$ mice $)[220,221]$ & Pancreas & Presence of TLSs; Reduced after LT $\beta$ R-Ig treatment \\
\hline Inflammed thyroid (TG-CCL21 mice) [222-224] & Thyroid & $\begin{array}{l}\text { Present in Id2 } 2^{-/-} \text {; Absent in } \operatorname{Rag} 1^{-/-} \text {mice and phenotypic res- } \\
\text { cue with adoptive transfer of CD4 } 4^{+} \mathrm{T} \text { cells; MECA-79 } \mathrm{HEV} \text { - } \\
\text { like blood vessels with only abluminal expression of PNAd, } \\
\text { flat morphology and no expression of the HEV-restricted sul- } \\
\text { fotransferase GlcNAc6ST-2 (Chst4) in LT } \alpha^{-/-} \text {mice; Absent } \\
\text { after LT } \beta \text { R-Ig treatment; Presence of TLSs }\end{array}$ \\
\hline \multicolumn{3}{|l|}{ Organ transplant rejection } \\
\hline Cardiac allografts $[225,226]$ & Heart & $\begin{array}{l}\text { Reduced after LT } \beta \text { R-Ig treatment; Presence of TLSs; Present in } \\
\text { TLSs and outside TLSs in lymphocyte-rich areas }\end{array}$ \\
\hline
\end{tabular}

AdV5 replication-defective adenovirus 5, BALT bronchus-associated lymphoid tissue, CCL19 CC-chemokine ligand 19, DKO mice lacking the chemokines CXCL13, CCL19 and CCL21a, H8 mice transgenic mice constitutively expressing the LCMV immunodominant epitope GP33, $i B A L T$ inducible BALT, $L C M V$-GP lymphocytic choriomeningitis virus glycoprotein, $L P S$ lipopolysaccharide, $L T$ lymphotoxin $\alpha, L T \alpha \beta$ lymphotoxin $\alpha$ and $\beta, N O D$ non-obese diabetic, $N Z B / W$ New Zealand black $\times$ New Zealand white F1 mice, plt/plt mice lacking CCL19 and CCL21a, $R I P$ rat insulin promoter, $T G$ thyroglobulin, $T L S s$ B cell-rich tertiary lymphoid structures, $\mu M$ B-cell-deficient mice

infiltrates, but they are also frequently associated with highly organized lymphoid clusters defined as tertiary lymphoid structures (TLSs) (Table 2) [6, 147, 227]. TLSs, also known as tertiary lymphoid organs (TLOs) [228], demonstrate several features of lymphoid organs, including compartmentalization of $\mathrm{B}$ and $\mathrm{T}$ cells in discrete zones, presence of dendritic cells and formation of HEV-like blood vessels [147]. By mediating lymphocyte entry into TLSs, HEV-like blood vessels may be critical for their maintenance and their function. The development of TLSs, referred to as lymphoid neogenesis [147, 148, 227], is observed in various chronic inflammatory diseases and is generally associated with deleterious outcomes in patients [148, 228, 229]. Indeed, several lines of evidence indicate that TLSs not only recapitulate the cellular and structural organization of lymphoid tissues, but can also support immune functions. In particular, TLSs can contain active germinal centers that foster B cell responses in situ [230-232], suggesting that TLSs might be regarded as B cell-oriented structures, at least regarding functional aspects.

\section{Mechanisms regulating the development of HEV-like blood vessels in chronic inflammation}

HEV-like blood vessels are nearly always present when pronounced lymphocyte infiltration is present over the course of chronic inflammation, suggesting an important role of lymphocytes in the development of these specialized blood vessels. Interestingly, a growing body of evidence indicate that several mechanisms occurring during the development of physiological HEVs in lymphoid tissues are involved in the development of ectopic HEV-like blood vessels, with an especially strong participation of cytokines and chemokines.

As mentioned in the introduction, initial morphometric studies made by Ziff with electron microscopy revealed that HEV-like blood vessel "plumpness", which can be regarded as a surrogate of HEV maturity, is associated with the number of perivascular lymphocytes [24]. Another feature highlighting the close relationship between HEV-like blood vessels and lymphocytes is the increased intensity of MECA-79 staining of HEV-like endothelial cells localized close to the lymphocytic infiltrates (Fig. 4a). These observations suggested that HEV-like blood vessel development could be the consequence of lymphocyte infiltration in chronically inflamed tissues. Subsequent studies further documented the intimate relationship between $\mathrm{HEV}$-like blood vessels and lymphocytes [149, 157]. A striking finding is the influence of the nature of the immune infiltrate on the presence or absence of HEV-like blood vessels in diseases occurring in the same organs. For instance, MECA- $79^{+} \mathrm{HEV}$-like blood vessels are induced in the skin and lungs during diseases associated with lymphocyte infiltration, such as psoriasis and bronchial asthma, but they are absent during diseases characterized by neutrophil infiltration, like vasculitis in the skin or adult respiratory distress syndrome in the lung [149, 157]. These observations suggest that HEV-like blood vessel induction is a hallmark of lymphocyte infiltration in 
chronically inflamed tissues, and that lymphocytes might be regulating their development and maintenance.

Mouse models of chronic inflammation have been instrumental for the identification of the mechanisms regulating HEV-like blood vessel development (Table 2). A major contribution of lymphoid tissue-associated cytokines and chemokines is strongly supported by results obtained in transgenic mice in which MECA- $79^{+}$HEV-like blood vessels are induced in pancreatic islets or thyroid in response to ectopic expression of TNF/lymphotoxin cytokines, CCL21 or CXCL13 [213, 214, 216, 217, 219]. LT $\alpha$ and LT $\beta$ have a central role in HEV development during LN organogenesis [233], and a similar scenario may apply for the de novo induction of HEV-like blood vessels. However, the phenotype of ectopic HEVs vary depending on the nature of the stimulus. When LT $\alpha$ is overexpressed in pancreatic islets, MECA-79+ HEV-like blood vessels exhibit mostly abluminal expression of MECA-79 antigens due to the absence of the sulfotransferase GlcNAc6ST-2 (Chst4) responsible for MECA-79 luminal expression [191, 234], and their development is dependent on TNFR1 signaling [218, 219]. On the other hand, co-expression of LT $\alpha$ and LT $\beta$ and consequent LT $\beta R$ signaling in the exocrine pancreas is associated with the development of MECA-79+ $\mathrm{HEV}$-like blood vessels expressing GlcNAc6ST-2 and high levels of luminal MECA79 antigens [219]. These landmark studies of Ruddle et al. indicate that TNFR1 signaling is sufficient to initiate the formation of MECA-79 ${ }^{+} \mathrm{HEV}$-like blood vessels but that LT $\beta \mathrm{R}$ signaling is required to generate vessels with increased HEV maturity and that might have an improved ability to capture L-selectin-expressing lymphocytes (Fig. 4b). Chemokines may induce HEV neogenesis through the recruitment of lymphocytes expressing LT $\beta R$ ligands. Indeed, MECA-79 ${ }^{+}$ HEV-like blood vessels induction in pancreatic islets following CCL21 or CXCL13 ectopic expression is abolished or reduced in lymphocyte-deficient mice [214, 216]. Moreover, crossing these transgenic mice with $\mathrm{LT}^{-/-}$mice or treating them with LT $\beta$ R-Ig significantly reduces HEV-like blood vessel development [213, 216]. In fact, it was demonstrated that CCL21 and CXCL13 upregulate LT $\beta$ R ligands on $\mathrm{CD}^{+} \mathrm{T}$ cells and $\mathrm{B}$ cells, respectively [213], showing that chemokines cooperate with TNF/lymphotoxin cytokines for the induction of HEV-like blood vessels in chronic inflammation. Interestingly, MECA-79+ $\mathrm{HEV}$-like blood vessels induced in the thyroid after ectopic expression of CCL21 are lost in lymphocyte-deficient mice but can be rescued following adoptive transfer of $\mathrm{CD} 4^{+} \mathrm{T}$ cells $[222,223]$. These later results confirmed that lymphocytes are critical regulators of HEV-like blood vessels, but also suggested that $\mathrm{CD} 4^{+} \mathrm{T}$ cells, that are preferentially associated with HEV-like blood vessels in several human chronically inflamed tissues [158, 159, 165, 183], are major inducers of HEV-like blood vessels in chronic inflammation.

\section{Therapeutic targeting of HEV-like blood vessels in chronic inflammation}

Accumulating evidence indicates that HEV-like blood vessels induced at sites of chronic inflammation contribute to lymphocyte trafficking in the diseased tissue in a manner similar to lymphocyte homing in LNs. These specialized blood vessels sustain chronic inflammation and subsequent pathology. Therefore, their therapeutic targeting may offer a novel way of influencing the progression of chronic inflammation and could have broad applications because MECA$79^{+}$HEV-like blood vessels appear in many distinct human inflammatory diseases (Table 1).

The presence of MECA- $79^{+}$HEV-like blood vessels correlates with the progression of inflammation and disease severity in several human inflammatory pathologies. In Helicobacter pylori chronic gastritis, MECA- $79^{+} \mathrm{HEV}-$ like blood vessels are likely to contribute to the formation of mucosa-associated lymphoid tissue (MALT) of the gastric mucosa that fosters local tissue inflammation and increases the risk of extranodal marginal zone lymphoma of MALT type (MALT lymphoma) [235-237]. By examining more than 140 human specimens, Fukuda and coworkers demonstrated that MECA-79+ ${ }^{+}$HEV-like blood vessels positively correlated with the progression of inflammation in the gastric mucosa [235]. Furthermore, they showed that eradication of $H$. pylori by treatment with antibiotics and a proton pump inhibitor is associated with the disappearance of HEV-like blood vessels and minimal lymphocyte infiltration, suggesting that local post-capillary venules reacquire a normal phenotype after treatment and are no longer able to sustain extensive lymphocyte recruitment. Therapeutic agents also have an impact on HEV-like blood vessels in other diseases. For instance, in RA and psoriatic arthritis, reduced inflammation in the synovium after TNF $\alpha$ blockade with different biological agents (adalimumab, infliximab, etanercept) was associated with reduced numbers of MECA$79^{+}$HEV-like blood vessels [153, 238]. Inflammatory bowel diseases (IBDs) such as ulcerative colitis provide another example of inflammatory pathologies in which HEV-like blood vessels are involved and modulated during disease progression [152, 157-161]. Analysis of colonic mucosa biopsies representing both active and remission phases of ulcerative colitis revealed that MECA- $79^{+}$HEV-like blood vessels are preferentially induced in the active phase of the disease $[158,161]$. Finally, similar clinical correlations were observed in other human inflammatory disorders including begnin prostatic hyperplasia, chronic maxillary rhinosinusitis and acute heart allograft rejection [168, 177, 183], indicating that HEV-like blood vessels are tightly associated with persistent inflammation and active disease in humans.

Interfering with the development and/or maintenance of HEV-like blood vessels or with HEV-associated molecules 
controlling lymphocyte recruitment is likely to provide therapeutic benefits in many human inflammatory diseases (Table 1). In fact, several reports mention disease amelioration following therapeutic manipulation of HEV-like blood vessels in preclinical models. In a sheep model of human asthma associated with development of MECA-79 ${ }^{+}$ HEV-like blood vessels in the lung, Rosen et al. showed that intravenous administration of MECA-79 antibody prevents airway hyper-responsiveness induced by allergen challenge and inhibits the accumulation of leukocytes in bronchoalveolar lavage fluid [150]. These results provided the first evidence that direct targeting of MECA-79+ HEV-like blood vessels can have therapeutic efficacy [150]. Similar findings were obtained in the same model using an antiL-selectin mAb instead of MECA-79 [239]. Interestingly, blockade of L-selectin function has been associated with reduced leukocyte recruitment in various inflammatory conditions [240] and can inhibit insulitis and subsequent development of diabetes in NOD mice [241]. Another relevant approach for HEV-like blood vessel inhibition is the targeting of the HEV master regulator LT $\beta$ R. In NOD mice, inhibition of MECA-79 ${ }^{+}$HEV-like blood vessels after treatment with LT $\beta$ R-Ig is associated with improved function of salivary and lacrimal glands [194, 195], suggesting that LT $\beta R$ inhibition may ameliorate disease in human Sjögren's syndrome. Interestingly, LT $\beta$ R-Ig reduces development of MECA- $79^{+}$HEV-like blood vessels in several murine tissue sites, including inflamed pancreatic islets, heart transplant allografts, and inflamed aorta during atherosclerosis in apo $E^{-/-}$mice (Table 2) [201, 216, 225]. However, a human LT $\beta$ R-Ig fusion protein (Baminercept) failed to produce significant clinical efficacy in RA and Sjögren's syndrome $[242,243]$. The unique targeting of lymphocyte recruitment to inflamed tissues may thus not be sufficient to yield therapeutic benefits. The simultaneous targeting of distinct steps of the lymphocyte-dependent response with combination of different treatments will likely provide maximal therapeutic benefits in humans.

\section{Tumor-associated HEVs (TA-HEVs) in cancer immunology and immunotherapy}

\section{MECA-79 ${ }^{+}$TA-HEVs in tumors}

Although detrimental in chronic inflammatory diseases, the development of HEV-like blood vessels can be advantageous in other instances where increased lymphocyte recruitment is beneficial. The immune response against cancer is critically dependent on the activity of tumor-specific lymphocytes that are able to recognize and eliminate tumor cells. To get inside the tumor, lymphocytes first need to extravasate through tumor blood vessels. By facilitating lymphocyte trafficking to the tumor, TA-HEVs could play a key role in cancer immunity and immunotherapy.

The first descriptions of MECA-79 ${ }^{+} \mathrm{HEV}$-like blood vessels in a human cancer setting were reported in cutaneous and gastric MALT lymphomas [51, 244, 245]. Given the known role of lymphocytes in the regulation of HEV-like blood vessels, it is not surprising that such vessels are present in extra-lymphoid tissues where malignant lymphoid cells accumulate. However, we now know that the development of MECA-79+ HEV-like blood vessels go far beyond lymphoid neoplasms, and they are in fact observed in many distinct human solid tumors [28], demonstrating that acquisition of HEV-specific attributes by tumor blood vessels is a widely conserved process in malignant tissues. Our initial observations showing the strong correlation between the density of MECA-79+ TA-HEVs and densities of tumorinfiltrating $\mathrm{CD}^{+}{ }^{+} \mathrm{T}$ cells, $\mathrm{CD} 8^{+} \mathrm{T}$ cells, and $\mathrm{CD} 20^{+} \mathrm{B}$ cells in primary breast cancer and melanoma [28, 29], have been confirmed in many studies and extended to multiple human malignancies (Table 3 ). The density of MECA- $79^{+}$TAHEVs is positively correlated with clinical parameters indicative of reduced tumor progression and invasion in primary melanoma [29, 246, 247] and with increased metastasis-free survival and overall survival in primary breast cancer [28]. MECA- $79^{+}$TA-HEVs are also associated with increased lymphocyte infiltration, progression free-survival and overall survival in head and neck cancer [248-250]. Moreover, combined high densities of MECA-79 ${ }^{+}$TA-HEVs and $\mathrm{CD}^{+}$ $\mathrm{T}$ cells are a prognostic factor for overall survival in gastric cancer [251]. Together, these results suggest that TA-HEVs function as major gateways for lymphocyte infiltration into human tumors, thus promoting antitumor immune response and improving clinical outcome.

MECA-79 ${ }^{+}$TA-HEVs express pan-endothelial cell markers such as CD31 or von Willebrand factor (vWF) but also the marker DARC, indicating that they likely derive from post-capillary venules similar to HEV-like blood vessels in chronic inflammation [28, 29]. Endothelial cells lining human MECA-79 ${ }^{+}$TA-HEVs exhibit a cuboidal appearance reminiscent of the plump morphology of LN HECs (Fig. 5), but they can also display a flat morphology, frequently associated with a dilated vessel lumen [138, 246, 249]. As observed in chronic inflammatory diseases, MECA-79 ${ }^{+}$TAHEVs might encompass a wide spectrum of HEV-like blood vessels with different degrees of maturation. Besides human studies, a main part of our knowledge on TA-HEVs come from studies performed in mouse models. Table 4 lists the different mouse tumors exhibiting MECA-79 ${ }^{+}$TA-HEVs. MECA- $79^{+}$TA-HEVs were first observed in mice following various treatments such as adoptive transfer of $\mathrm{CD} 8^{+}$ $\mathrm{T}$ cells, administration of tumor-targeted LT $\alpha$ or genetic depletion of Foxp3 ${ }^{+}$regulatory T cells (Tregs) [282-285]. However, Engelhard et al. demonstrated that, in some tumor 


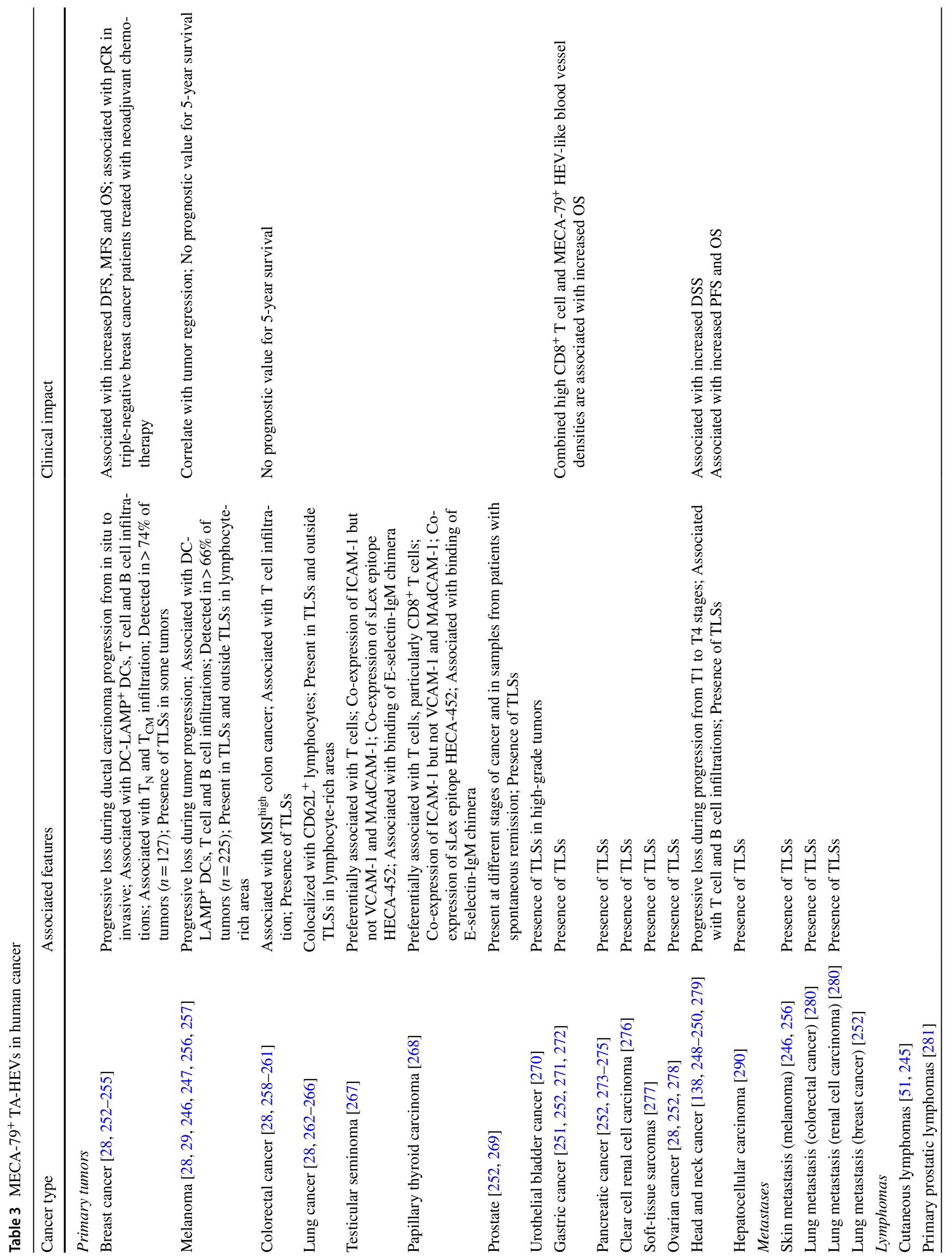


models, MECA-79+ TA-HEVs can spontaneously develop in the tumor microenvironment in the absence of any treatment [286]. Importantly, TA-HEVs are induced in different types of tumors, including subcutaneous transplanted tumors, orthotopically transplanted tumors and genetically engineered tumor models [252, 266, 286, 287]. In contrast to their human counterparts, endothelial cells lining mouse MECA- $79^{+}$TA-HEV senerally do not exhibit the HEVspecific cuboidal shape and they are characterized by a flat morphology associated with reduced expression of MECA79 in comparison with LN HEVs [282, 286]. Nevertheless, they are surrounded by high numbers of lymphocytes akin to human TA-HEVs, providing an early clue to their functional significance [286]. Based on short-term in vivo homing assays, it was shown that MECA-79+ ${ }^{+}$TA-HEV s are associated with the recruitment of naive lymphocytes into tumors [286], suggesting that LN HEV functional properties are conserved to some degree by TA-HEVs, and that HEV-mediated homing of lymphocytes in LN might be recapitulated in tumors. This later possibility is also supported by human studies in which high densities of MECA-79+ TA-HEVs correlated with increased infiltration of naive and central memory $\mathrm{T}$ cells [28].

The recruitment of naive $\mathrm{T}$ cells into tumors is of particular interest since their priming and subsequent conversion into effectors can be realized directly within the tumor [301, 302]. Bypassing activation of naive T cells in LNs is proposed to accelerate and foster antitumor response and is likely to occur in tumor TLSs [303, 304]. TA-HEVs are present in B-cell rich TLSs that develop in some human tumors (Fig. 6a) [277, 303, 305] and might contribute to their function in a similar way to HEV-like blood vessels in TLSs from chronic inflammatory diseases [306-310]. However, TA-HEVs and tumor-associated TLSs are two distinct elements. Indeed, TA-HEVs are more frequent than TLSs in human tumors. For instance, we detected MECA$79^{+}$TA-HEVs in $>74 \%$ of primary breast tumors $(n=127)$ [28], whereas TLSs were found in only $37 \%$ of tumors in a cohort of 248 breast cancer patients [311]. In primary melanoma, we found TA-HEVs in $>66 \%$ of tumors $(n=225)$ [29], whereas TLSs are rarely detected in primary melanoma lesions [256]. Indeed, MECA-79 ${ }^{+}$TA-HEVs are often found in T-cell rich areas containing DCs but no B cell follicles (Fig. 6b) [29, 247, 253, 256, 262]. These structures enriched in T cells and DCs, that are highly similar to the T-cell zones of lymphoid tissues, may provide a supportive niche for $\mathrm{CD}^{+} \mathrm{T}$ cells in human tumors [312]. Jansen et al. also reported the presence of TLSs in their tumor samples [312], but these TLSs were located in distinct areas and were mainly composed of $\mathrm{B}$ cells, suggesting that $\mathrm{CD} 8^{+}$ $\mathrm{T}$ cell- and $\mathrm{B}$ cell-dependent responses may occur in distinct structures in human tumors. Whether TA-HEVs are an integral part of the T-cell oriented structures remains to be 
a

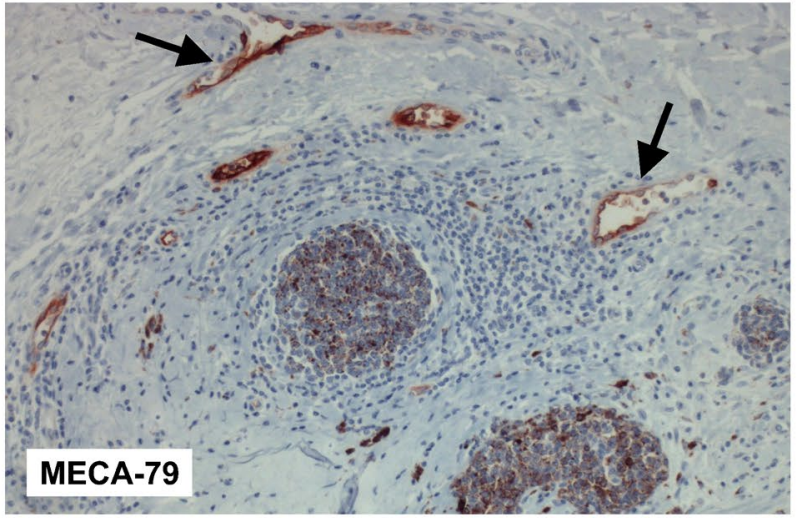

melanoma

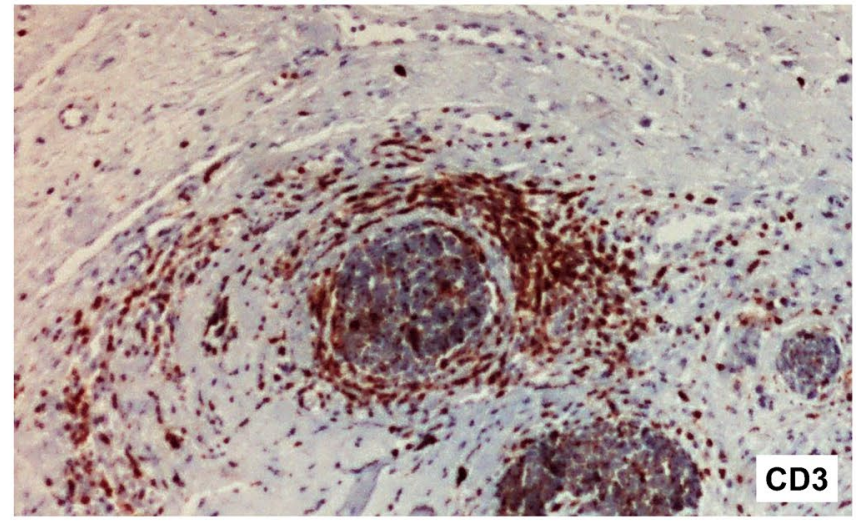

b

breast cancer

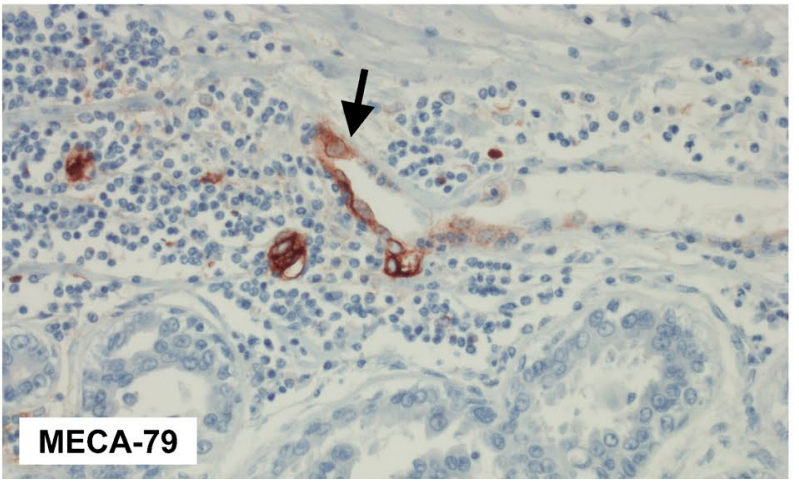

Fig. 5 TA-HEVs and $\mathrm{T}$ cell infiltration in human primary melanoma and breast cancer. a MECA- $79^{+}$TA-HEVs in human primary melanoma. TA-HEVs are present in a regressing tumor area infiltrated by $\mathrm{CD}^{+} \mathrm{T}$ cells. $\mathbf{b}$ MECA-79 ${ }^{+} \mathrm{TA}-\mathrm{HEV}$ s in human primary breast can-

confirmed, but the known association of TA-HEVs with both T cells and DCs in human tumors is in agreement with this hypothesis [28, 29, 253].

Importantly, although TLSs containing MECA-79+ TAHEVs are associated with a favorable clinical outcome in most cancer types [303], they may be detrimental in some instances. Hepatocellular carcinoma (HCC) is an inflammation-driven cancer characterized by abundant TLSs that were associated with increased risk of recurrence [290]. In fact, Finkin et al. demonstrated that TLSs could serve as niches for malignant hepatocyte progenitors in an HCC mouse model, suggesting that TLSs could support tumor progression in inflammation-dependent tumors. In addition, TLSs have been reported to be privileged sites for Treg accumulation in some mouse tumor models [289, 292]. Therefore, TLSs are generally associated with antitumor functions but could also shelter cells promoting tumor growth, showing that the impact of TLSs on prognosis is dependent on cancer types.

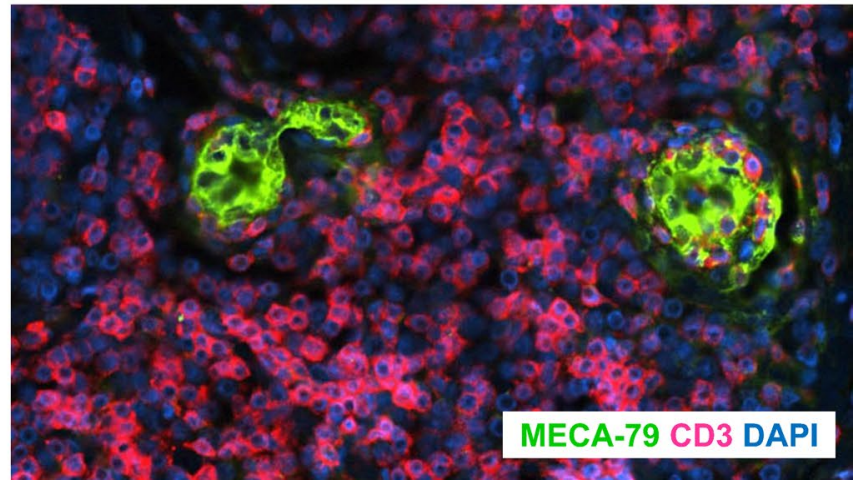

cer. TA-HEVs are present in tumor areas infiltrated by $\mathrm{CD}^{+} \mathrm{T}$ cells. MECA-79 staining is more intense on the side of the blood vessels in contact with the lymphocytic infiltrate (arrows). See original references from Martinet, Garrido et al. [28, 29]

\section{Mechanisms regulating the development of TA-HEVs in cancer}

Induction of TA-HEVs in solid tumors highlights the remarkable capacity of immune cells to modify their target tissue to maximize the immune response, even in highly hostile microenvironments. Despite similarities with HEV-like blood vessels of chronic inflammatory diseases, the mechanisms regulating TA-HEV development also have distinctive features related to the particular nature of solid tumors. Determining the cellular actors and molecular signals triggering the HEV differentiation program in tumor blood vessels is essential to better define their role in antitumor immunity, and to provide important insights for the design of novel therapeutic approaches based on TA-HEV induction.

Because DCs control HEV phenotype and function in lymph nodes [94] and since they are frequently associated with TA-HEVs in human melanoma and breast cancer [29, 253], lymphotoxin-expressing DCs were initially proposed as critical regulators of TA-HEVs in humans [313]. 


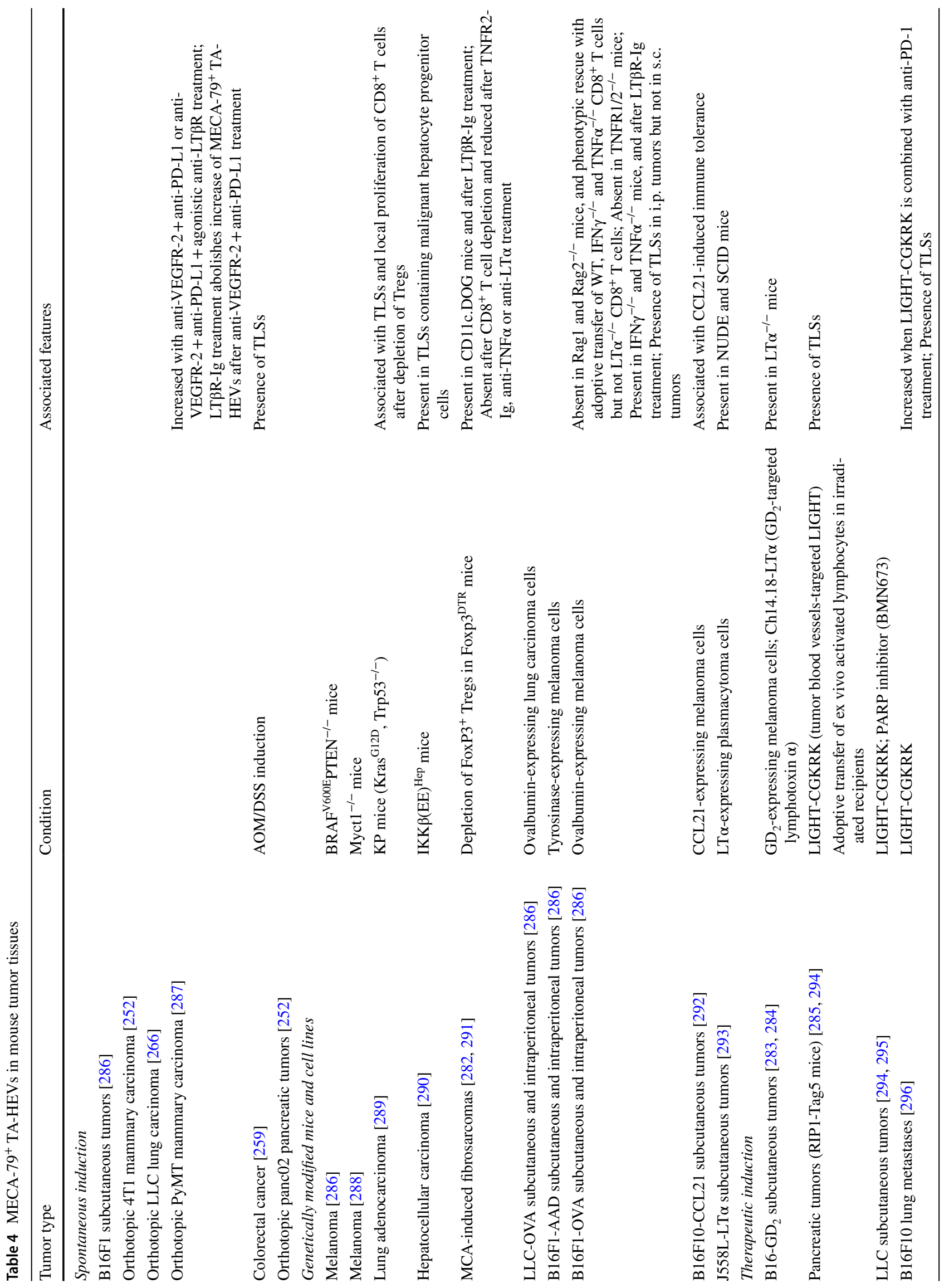


However, results obtained in mouse models point towards a more dominant role for lymphocytes. As observed for HEV-like blood vessels in models of chronic inflammation, MECA-79+ ${ }^{+}$TA-HEVs are lost in tumors grown in lymphocyte-deficient $\mathrm{Rag}^{-/-}$mice [286]. Moreover, adoptive transfer of $\mathrm{CD}^{+} \mathrm{T}$ cells is sufficient to induce develop-

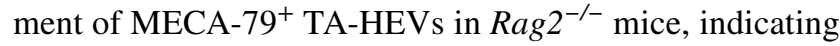
that $\mathrm{CD} 8^{+} \mathrm{T}$ cells could be major inducers of TA-HEVs in tumors. In contrast, Tregs, which are known as major immunosuppressive cells in the tumor microenvironment, seem to limit TA-HEV development in tumors as revealed by the induction of MECA-79+ TA-HEVs following depletion of Foxp3-expressing cells in Foxp $3^{\text {DTR }}$ mice $[282,291]$. Whether Tregs inhibit HEV neogenesis via direct action on tumor blood vessels or indirectly via inhibition of lymphocyte subsets critical for TA-HEV development is currently unknown. Interestingly, depletion of $\mathrm{CD} 8^{+} \mathrm{T}$ cells was shown to abrogate MECA- $79^{+}$TA-HEV induction consecutive to Treg depletion [291], confirming the important role of $\mathrm{CD}^{+} \mathrm{T}$ cells in the regulation of TA-HEVs. The increased MECA-79 staining of TA-HEV endothelial cells in close proximity with $\mathrm{CD}^{+} \mathrm{T}$ cells in human primary melanoma (Fig. 5) further highlights the importance of lymphocytes in TA-HEV regulation. Together, these results indicate that lymphocytes are able to induce specialized blood vessels facilitating their trafficking into tumors, revealing an important immune-vascular crosstalk in favor of antitumor immunity.

MECA-79+ TA-HEVs observed in mouse tumor models express low amounts of MECA-79 antigens at their surface. In line with this immature phenotype, their development is critically dependent on TNFR $1 / 2$ signaling and not LT $\beta \mathrm{R}$ pathway. Indeed, TNFR $1 / 2^{-/-}$mice do not develop TAHEV s while treatment with LT $\beta$ R-Ig has no impact on the development of MECA- $79^{+}$TA-HEVs in wild type mice [286]. Similar findings were obtained for TA-HEVs induced following Treg depletion as their development is blocked by TNFR-Ig fusion protein but not LT $\beta R$-Ig [291]. Because TA-HEVs are not affected in $\mathrm{TNF}^{-/-}$mice and because $\mathrm{LT} \alpha^{-/-} \mathrm{CD} 8^{+} \mathrm{T}$ cells induce significantly less MECA-79 ${ }^{+}$ TA-HEVs in lymphocyte-deficient mice than wild type CD8 ${ }^{+}$T cells, LT $\alpha$, a TNFR 1 ligand, was proposed as a key mediator for the development of TA-HEVs [286]. Consistent with this, tumors of mice treated with tumor-targeted LT $\alpha$ or bearing cancer cells genetically engineered to secrete LT $\alpha$ develop MECA-79+ TA-HEVs whereas control tumors are devoid of such vessels [283, 284, 293]. Although LT $\beta R$ signaling is not required for the development of most TAHEVs observed in mouse tumors, several reports indicate that stimulation of this receptor leads to the development of MECA- $79^{+}$TA-HEVs. Indeed, treatment with the LT $\beta R$ ligand LIGHT or LT $\beta$ R agonistic antibodies is sufficient to induce TA-HEVs in mouse tumors [287, 294, 296, 297]. 
a

TA-HEVs in a CD20+ B cell-rich TLS (breast cancer)
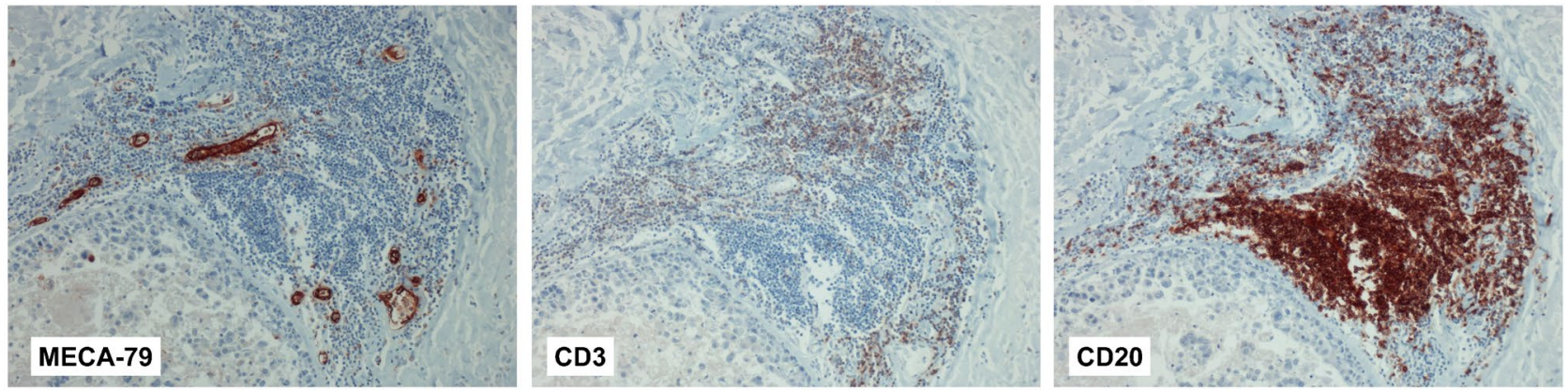

b

TA-HEVs in a CD3+ $\mathrm{T}$ cell-rich area (melanoma)
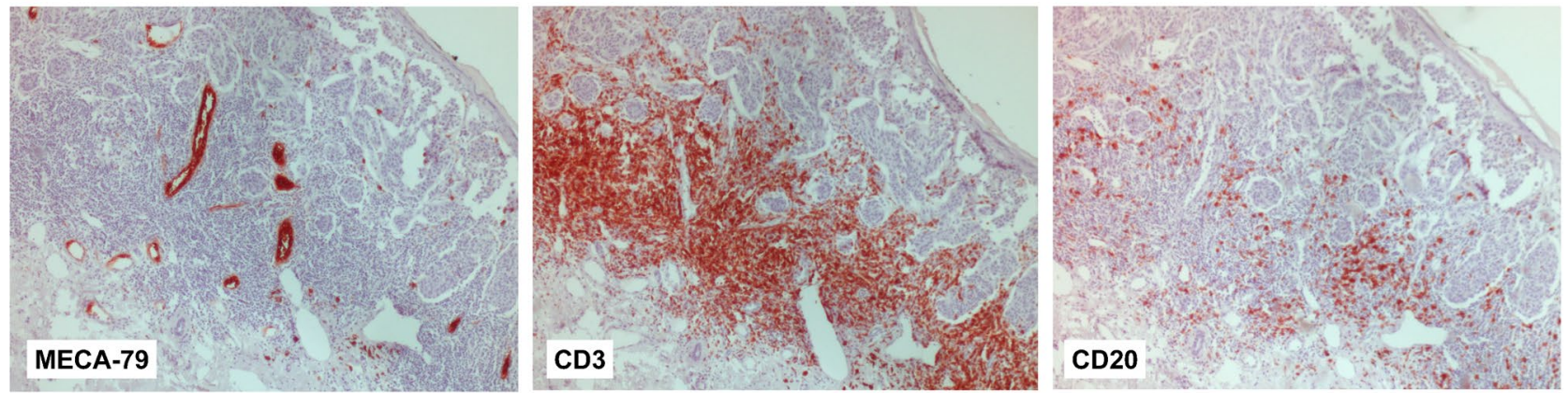

Fig. 6 TA-HEVs are present in both T cell-rich areas and B cell-rich TLSs. a MECA-79+ TA-HEVs in human primary breast cancer. TAHEVs are present in a tumor area highly infiltrated by $\mathrm{CD} 20^{+} \mathrm{B}$ cells. These lymphoid aggregates enriched in B cells are designated B cell-

Therefore, LT $\beta R$ signaling is dispensable for the development of mouse TA-HEVs, which probably explains their relative immaturity in comparison to LN HEVs, but therapeutic targeting of this receptor induces TA-HEVs. The two-step differentiation model of HEV-like blood vessels in chronic inflammation could also be true for TA-HEVs (Fig. 4). However, additional studies are required to determine if LT $\beta R$ stimulation is actually able to increase the degree of maturation of mouse TA-HEVs. Signaling through LT $\beta R$ may be critical for induction of fully mature TA-HEVs in tumors.

The association of histological examinations of TAHEVs with clinical parameters indicate that TA-HEV density is dependent on the tumor stage in humans. Breslow tumor thickness is used as a prognostic biomarker for staging primary cutaneous melanomas and it was shown that densities of MECA-79+ TA-HEVs are inversely correlated with Breslow thickness, indicating that TA-HEVs are more abundant during the initial stages of melanoma [29]. Analysis of head and neck cancer with the tumornode-metastasis (TNM) staging system revealed that T1 tumors exhibit higher densities of TA-HEVs as compared to tumors of later stages [248, 249]. Interestingly, the progression from in situ to invasive ductal carcinoma is associated with a progressive loss of TA-HEVs in breast cancer [253]. These correlations suggest that induction of rich TLSs. b MECA-79 ${ }^{+}$TA-HEVs in human primary melanoma. TA-HEVs are present in a tumor area highly infiltrated by $\mathrm{CD}^{+} \mathrm{T}$ cells and by some $\mathrm{CD} 20^{+} \mathrm{B}$ cells with no apparent organization into TLSs. See original references from Martinet, Garrido et al. [28, 29]

TA-HEVs is maximal during the initial stages of tumor development when the immune response is likely to be the highest. In fact, results obtained in transgenic mice expressing the oncoprotein Tag (simian virus 40 large $\mathrm{T}$ antigen) under control of the rat insulin gene regulatory region (RIP1-Tag5 mice) corroborate the observations obtained in human tumors. In RIP1-Tag5 mice, Tag expression in the insulin-producing cells of the pancreatic islets induces multistage carcinogenesis of pancreatic islets starting with benign hyperplasia and ending with the development of solid tumors and premature death [314]. In striking contrast to the highly infiltrated hyperplastic islets that contain MECA- $79^{+}$TA-HEVs, tumors are poorly infiltrated by lymphocytes and do not develop TAHEVs although they are highly vascularized [212]. These observations confirmed that tumor progression influences the presence of TA-HEVs and suggested that tumor immunogenicity may control induction and/or maintenance of TA-HEVs. In agreement with this later possibility, mice with B16F1 tumors contain far less MECA-79+ TA-HEVs than mice with $\mathrm{B} 16 \mathrm{~F} 1$ tumors expressing ovalbumin that are known to elicit robust lymphocyte-dependent antitumor response because of the high level of antigenicity of ovalbumin [286]. Therefore, the presence of TA-HEVs in tumors might be a good proxy to evaluate the intensity 
of the ongoing antitumor immune response. The loss of TA-HEVs during tumor progression may be due to the loss of strong neoantigens by cancer immunoediting [315, 316]. However, the impact of cancer immunoediting on TA-HEVs is currently unknown.

\section{Therapeutic induction of TA-HEVs in cancer}

Trafficking of lymphocytes to tumors is critical for antitumor immunity and cancer immunotherapy with immune checkpoint inhibitors (ICIs), vaccines or adoptive T cell therapy (ACT) [317-321]. Tumor-infiltrating lymphocytes (TILs) are associated with improved clinical outcome in many cancers, and the presence of high numbers of $\mathrm{CD} 8^{+} \mathrm{T}$ cells in human tumors is predictive of therapeutic response to cancer treatments, especially to ICIs [322-325]. However, the mechanisms governing the magnitude of the $\mathrm{CD} 8^{+} \mathrm{T}$ cell response remain incompletely defined. Why some tumors have high $\mathrm{CD} 8^{+} \mathrm{T}$ cell infiltration while others have poor infiltration is not entirely clear. Increasing the density and maturation of MECA-79+ $9^{+}$TA-HEVs in the tumor microenvironment may enhance lymphocyte trafficking to tumors and improve the efficacy of various cancer treatments (Fig. 7), including immunotherapies with ICIs, ACT or vaccines, but also potentially targeted therapies and conventional cancer therapies (radiotherapy, chemotherapy).

Checkpoint blockade therapy with anti-PD-1 and antiCTLA-4 antibodies provides remarkable and durable responses for many patients across different types of cancer [317, 318, 320]. However, ICIs do not benefit all patients and novel therapeutic strategies are required for increasing their efficacy. Recent studies indicate that a subset of tumor-reactive $\mathrm{CD} 8^{+} \mathrm{T}$ cells may be critical for antitumor immunity at baseline and also for response to cancer immunotherapies with ICIs [312, 326-328]. This particular T cell subset encompasses less differentiated and less dysfunctional (exhausted) $\mathrm{CD} 8^{+} \mathrm{T}$ cells designated stem-like $\mathrm{CD} 8^{+}$ $\mathrm{T}$ cells because of their capacity to self-renew while being able to generate more differentiated effector $\mathrm{CD} 8^{+} \mathrm{T}$ cells. Interestingly, analyses of $\mathrm{T}$ cells in patients treated with ICIs revealed that continuous recruitment of fresh and less exhausted $\mathrm{T}$ cells from the periphery into the tumor may be important for clinical response [329, 330]. Together, these findings suggest that strategies aiming to ameliorate the migration of peripheral stem-like $\mathrm{CD} 8^{+} \mathrm{T}$ cells into tumors could result in increased numbers of patients responding to ICIs. As specialized blood vessels for lymphocyte trafficking, TA-HEVs may be major gateways for entry of stem-like $\mathrm{CD} 8^{+} \mathrm{T}$ cells into tumors, and their therapeutic modulation could enhance the infiltration of these critical cells, thus increasing the efficacy of ICIs. Infiltration of naïve and central memory $\mathrm{CD} 8^{+} \mathrm{T}$ cells, $\mathrm{CD} 4^{+} \mathrm{T}$ cells and $\mathrm{B}$ cells through TA-HEVs may also play important roles in the response to ICIs [277, 305] and other forms of cancer therapies (Fig. 7).

As expected, LT $\beta$ R agonists are potent inducers of TAHEVs in tumors. Targeting LIGHT directly to tumor blood

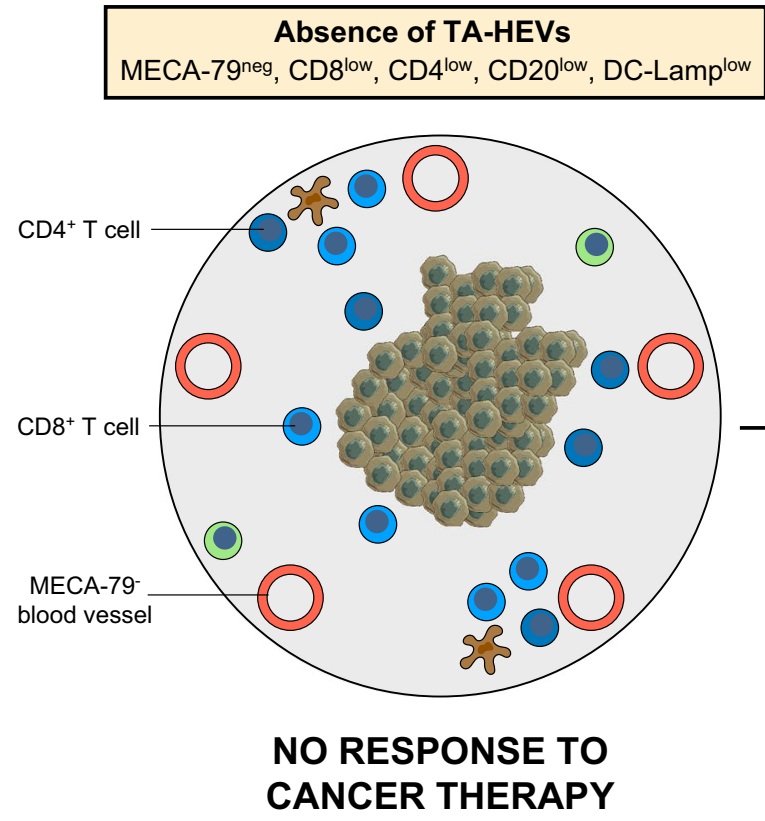

Fig. 7 Therapeutic induction of TA-HEVs for cancer therapy. Induction of MECA- $79^{+}$TA-HEVs in the tumor microenvironment may increase infiltration of various subsets of $\mathrm{CD}^{+}$and $\mathrm{CD} 4^{+} \mathrm{T}$ cells, as well as $\mathrm{CD} 20^{+} \mathrm{B}$ cells, and may improve antitumor immunity and
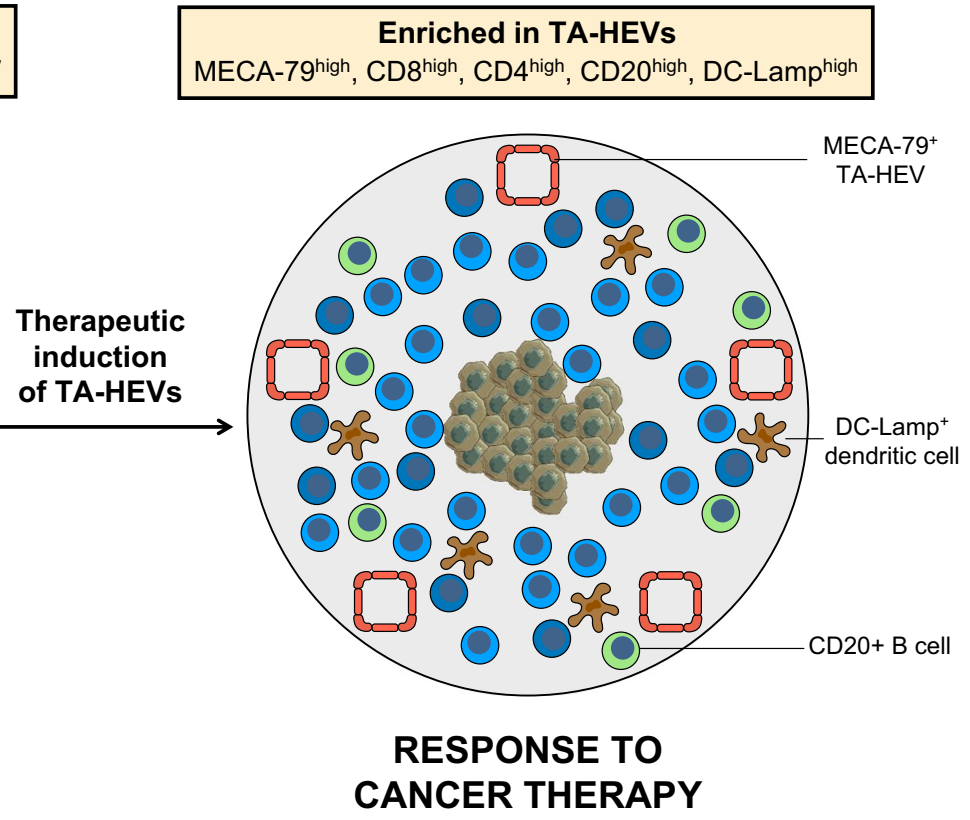

efficacy of various cancer treatments, including immunotherapies with immune checkpoint inhibitors, adoptive $\mathrm{T}$ cell therapy or vaccines, but also potentially targeted therapies and conventional cancer therapies (radiotherapy, chemotherapy) 
vessels via fusion to vascular targeting peptides (VTP) induces MECA-79+ ${ }^{+}$TA-HEVs in various mouse tumor models [294, 296, 297]. Similar results were obtained with a tumor-targeted nanoparticle co-loaded with an anti-fibrotic molecule and a plasmid encoding LIGHT [298]. LIGHTinduced development of TA-HEVs is associated with increased lymphocyte infiltration and response to ICIs [294]. Notably, LIGHT-associated therapies were also shown to overcome resistance to anti-PD-1 or anti-PD-L1 monotherapies and to sensitize refractory lung metastases to anti-PD-1 immunotherapy [296, 298, 331]. LT $\beta R$ agonistic antibodies (anti-LT $\beta R$ ) were also reported to induce MECA-79 ${ }^{+}$ TA-HEV and to enhance lymphocyte infiltration in distinct mouse tumor models, and treatment with anti-LT $\beta R$ enabled response to anti-VEGFR2 and anti-PD-L1 combination therapy in a recalcitrant glioblastoma model [287]. Different cell types express LT $\beta R$ in the tumor microenvironment. Therapeutic stimulation of LT $\beta R$ with LIGHT or LT $\beta$ R agonistic antibodies may thus reprogram intratumoral stromal cells and dendritic cells, in addition to blood vessel endothelial cells [332]. Along with LT $\beta R$ stimulation, TNFR1 stimulation may also provide an effective way to induce TA-HEVs. Indeed, previous studies with a tumor-targeted antibodyLT $\alpha$ fusion protein showed that stimulating TNFR1 in the tumor microenvironment was able to induce MECA-79+ TA-HEV and to eradicate established tumors [283, 284]. Whether these MECA- $79^{+}$tumor blood vessels are identical to MECA- $79^{+}$TA-HEVs induced through LT $\beta$ R stimulation warrants further studies, but in both instances, neogenesis of TA-HEVs correlated with a robust lymphocyte-mediated antitumor response. Intriguingly, other agents targeting signaling pathways not related to HEV biology induce TAHEVs. For instance, intratumoral injection of STING agonists (ADU-S100) or treatment with a PARP inhibitor (BMN 673 ) both induce MECA-79+ TA-HEVs in mouse tumor models [295, 299]. Together these studies in mice provide a proof-of-concept that induction of TA-HEVs within tumors can unleash lymphocyte-dependent immunity and improve therapeutic outcomes.

Therapeutic induction of TA-HEVs in tumors might enhance trafficking of endogenous lymphocytes but also of adoptively transferred lymphocytes. If cell-based immunotherapies with chimeric antigen receptor (CAR) T cells are showing great promises in the treatment of hematological malignancies (e.g. CD19-targeted CAR T cells for B-cell acute lymphocytic leukemia), they are usually ineffective for treatment of solid tumors [333]. Pre-conditioning the tumor vasculature for maximal lymphocyte trafficking through induction of TA-HEVs could thus provide therapeutic benefits in ACT immunotherapy of solid tumors, including with CAR T cells. Interestingly, the success of ACT using ex vivo-expanded autologous TILs is dependent on the presence of stem-like $\mathrm{CD} 8^{+} \mathrm{T}$ cells within transferred cells, demonstrating the crucial role of these particular $\mathrm{CD}^{+} \mathrm{T}$ cells in cell-based immunotherapies in human cancer [334]. In addition, several studies demonstrated that transferring less-differentiated $\mathrm{CD} 8^{+} \mathrm{T}$ cells (e.g. central memory $\mathrm{T}$ cells) elicit better antitumor responses during therapeutic ACT in mouse tumor models [335-337]. Therefore, the unique ability of TA-HEVs to capture naive and naive-like lymphocytes might be particularly valuable for ACT immunotherapy, especially when using early differentiated cells that express L-selectin and CCR7.

\section{Conclusion}

Blood vessels that are structurally and phenotypically similar to HEVs from lymphoid organs appear in non-lymphoid tissues during chronic inflammation and cancer. HEV-like blood vessels in chronically inflamed tissues and TA-HEVs in tumors are associated with lymphocyte infiltration similar to lymphoid tissue HEVs, indicating that induction of specialized blood vessels for lymphocyte trafficking is a universal property of tissues exposed to intense lymphocyte activity. In chronic inflammatory diseases, HEV-like blood vessels facilitate influx of pathological lymphocytes, leading to amplification and maintenance of chronic inflammation. In contrast, TA-HEVs are generally beneficial in cancer, showing that the clinical significance of ectopic HEV-like blood vessels is highly dependent on the pathological context.

In the past 30 years, there has been considerable progress in our understanding of the mechanisms regulating the phenotype and function of HEVs in LNs, both at steady state and following immune challenge. However, several questions remain regarding the phenotype and functionality of HEV-like blood vessels and TA-HEVs. For instance, the use of intravital microscopy, which is the only experimental approach enabling visualization of lymphocyte recruitment through blood vessels in vivo [52], will be crucial to demonstrate the functional competence of these vessels. In particular, determining the relative contribution of MECA$79^{+}$blood vessels versus MECA-79- ${ }^{-}$blood vessels will be important to confirm the increased capacity of HEV-like blood vessels and TA-HEVs to mediate lymphocyte recruitment into tissues. Recent transcriptomic analyses of mouse MECA- $79^{+}$HECs delineate the HEV phenotype in homeostatic and inflamed LNs [40, 53, 54]. Investigating the transcriptomes of endothelial cells lining HEV-like blood vessels and TA-HEVs and comparing them with those of LN HECs and non-HEV endothelial cells in mouse and human tissues could provide great insights about potential pathways for modulation of these vessels in chronic inflammation and cancer. 
Great promises stem from the potential of TA-HEVs to increase lymphocyte trafficking into tumors, especially for cancer immunotherapy, which has to face unmet clinical needs. Because of their unique ability to mediate the recruitment of L-selectin-expressing lymphocytes, therapeutic induction of MECA- $79^{+}$TA-HEVs could not only increase lymphocyte trafficking quantitatively, but also qualitatively by enabling the entry of specific lymphocyte subsets that may be critical for antitumor immunity. These may include naive, central memory and stem-like $\mathrm{CD} 8^{+} \mathrm{T}$ cells, but also $\mathrm{CD} 4^{+} \mathrm{T}$ cells and $\mathrm{B}$ cells $[277,305,338]$. However, we have to learn lessons from the clinical failure of therapeutic agents targeting HEV-like blood vessels in chronic inflammatory diseases. Solely inducing TAHEVs will be probably insufficient to obtain significant clinical responses, but therapeutic combinations with ICIs, ACT or other forms of cancer therapy are likely to provide important therapeutic benefits for cancer patients.

In chronic inflammation, MECA-79+ $\mathrm{HEV}$-like blood vessels accurately accompany lymphocyte-dependent activity and disease progression. Similar findings in solid tumors mean that MECA-79+ ${ }^{+}$TA-HEVs go along with antitumor immune response and may represent a biomarker to identify highly immunogenic tumors that are more likely to respond to cancer immunotherapies. Indeed, it is important to identify biomarkers predicting response to ICIs because they are widely used for metastatic patients who are frequently non-responsive and develop severe immune-related adverse events [318, 339]. Since MECA- $79^{+}$TA-HEVs are present in metastatic lesions, there is an urgent need to investigate their capacity to predict response to ICIs in cancer patients.

In this article, we presented a comprehensive review on HEVs and HEV-like blood vessels in immunity, inflammation and cancer. HEVs in lymphoid organs have fascinated many researchers over the past century. We are convinced that HEVs and HEV-like blood vessels will continue to attract the interest of scientists and clinicians in the next decades, particularly those working in the areas of vascular biology (angiogenesis), immunology, inflammation, cancer biology (tumor microenvironment) and cancer immunotherapy. Although many aspects of HEV-like blood vessels are still to be discovered, their therapeutic modulation already offers promising avenues, especially for cancer treatment.

Acknowledgements We thank all our colleagues in different parts of the world for their great contributions to the field. We regret that we could not always quote all the original publications. We thank actual and past members of our team for their essential contributions to the discoveries we have made on the HEV topic in the past 25 years. We are also grateful to all our collaborators in the clinics. Work in the Girard laboratory is supported by the Fondation ARC pour la Recherche sur le Cancer (SL220110603471, PGA 120150202411, PGA1 RF20180206911), Institut National du Cancer (INCa_2013-098, INCa_2017-155), Agence Nationale de la Recherche (ANR-12-BSV1-0006-01), IDEX UNITI (ATS 2014), Laboratoire d'Excellence Toulouse Cancer (LABEX TOUCAN) and the Fondation pour la Recherche Médicale (FRM ECO201806006827, FRM ECO202006011469).

Open Access This article is licensed under a Creative Commons Attribution 4.0 International License, which permits use, sharing, adaptation, distribution and reproduction in any medium or format, as long as you give appropriate credit to the original author(s) and the source, provide a link to the Creative Commons licence, and indicate if changes were made. The images or other third party material in this article are included in the article's Creative Commons licence, unless indicated otherwise in a credit line to the material. If material is not included in the article's Creative Commons licence and your intended use is not permitted by statutory regulation or exceeds the permitted use, you will need to obtain permission directly from the copyright holder. To view a copy of this licence, visit http://creativecommons.org/licenses/by/4.0/.

\section{References}

1. Girard JP, Moussion C, Forster R (2012) HEVs, lymphatics and homeostatic immune cell trafficking in lymph nodes. Nat Rev Immunol 12(11):762-773

2. Girard JP, Springer TA (1995) High endothelial venules (HEVs): specialized endothelium for lymphocyte migration. Immunol Today 16(9):449-457

3. Butcher EC, Picker LJ (1996) Lymphocyte homing and homeostasis. Science 272(5258):60-66

4. von Andrian UH, Mempel TR (2003) Homing and cellular traffic in lymph nodes. Nat Rev Immunol 3(11):867-878

5. Miyasaka M, Tanaka T (2004) Lymphocyte trafficking across high endothelial venules: dogmas and enigmas. Nat Rev Immunol 4(5):360-370

6. Rosen SD (2004) Ligands for L-selectin: homing, inflammation, and beyond. Annu Rev Immunol 22:129-156

7. Cayrol C, Girard JP (2018) Interleukin-33 (IL-33): a nuclear cytokine from the IL-1 family. Immunol Rev 281(1):154-168

8. Baekkevold ES, Roussigne M, Yamanaka T, Johansen FE, Jahnsen FL, Amalric F, Brandtzaeg P, Erard M, Haraldsen G, Girard JP (2003) Molecular characterization of NF-HEV, a nuclear factor preferentially expressed in human high endothelial venules. Am J Pathol 163(1):69-79

9. Carriere V, Roussel L, Ortega N, Lacorre DA, Americh L, Aguilar L, Bouche G, Girard JP (2007) IL-33, the IL-1-like cytokine ligand for ST2 receptor, is a chromatin-associated nuclear factor in vivo. Proc Natl Acad Sci USA 104(1):282-287

10. Thome R (1898) Endothelien als Phagocyten. Arch Mikrosk Anat 52:820-842

11. von Schumacher S (1899) Ueber Phagocytose und die Abfuhrwege de Leucocyten in den Lymphdrusen. Arch Mikrosk Anat 54:311-328

12. Gowans JL, Knight EJ (1964) The route of recirculation of lymphocytes in the rat. Proc R Soc Lond B 159:257-282

13. Marchesi VT, Gowans JL (1964) The migration of lymphocytes through the endothelium of venules in lymph nodes: an electron microscopic study. Proc R Soc Lond B 159:283-290

14. Wenk EJ, Orlic D, Reith EJ, Rhodin JA (1974) The ultrastructure of mouse lymph node venules and the passage of lymphocytes across their walls. J Ultrastruct Res 47(2):214-241

15. Anderson AO, Anderson ND (1976) Lymphocyte emigration from high endothelial venules in rat lymph nodes. Immunology 31(5):731-748

16. Anderson AO, Anderson ND (1975) Studies on the structure and permeability of the microvasculature in normal rat lymph nodes. Am J Pathol 80(3):387-418 
17. van Deurs B, Ropke C (1975) The postanatal development of high-endothelial venules in lymph nodes of mice. Anat Rec 181(3):659-677

18. Kikuta A, Rosen SD (1994) Localization of ligands for L-selectin in mouse peripheral lymph node high endothelial cells by colloidal gold conjugates. Blood 84(11):3766-3775

19. Anderson AO, Shaw S (1993) T cell adhesion to endothelium: the FRC conduit system and other anatomic and molecular features which facilitate the adhesion cascade in lymph node. Semin Immunol 5(4):271-282

20. Bao X, Moseman EA, Saito H, Petryniak B, Thiriot A, Hatakeyama S, Ito Y, Kawashima H, Yamaguchi Y, Lowe JB, von Andrian UH, Fukuda M (2010) Endothelial heparan sulfate controls chemokine presentation in recruitment of lymphocytes and dendritic cells to lymph nodes. Immunity 33(5):817-829

21. Tsuboi K, Hirakawa J, Seki E, Imai Y, Yamaguchi Y, Fukuda M, Kawashima H (2013) Role of high endothelial venuleexpressed heparan sulfate in chemokine presentation and lymphocyte homing. J Immunol 191(1):448-455

22. Freemont AJ (1988) Functional and biosynthetic changes in endothelial cells of vessels in chronically inflamed tissues: evidence for endothelial control of lymphocyte entry into diseased tissues. J Pathol 155(3):225-230

23. Freemont AJ, Jones CJ, Bromley M, Andrews P (1983) Changes in vascular endothelium related to lymphocyte collections in diseased synovia. Arthritis Rheum 26(12):1427-1433

24. Iguchi T, Ziff M (1986) Electron microscopic study of rheumatoid synovial vasculature. Intimate relationship between tall endothelium and lymphoid aggregation. J Clin Invest 77(2):355-361

25. Jalkanen S, Steere AC, Fox RI, Butcher EC (1986) A distinct endothelial cell recognition system that controls lymphocyte traffic into inflamed synovium. Science 233(4763):556-558

26. Freemont AJ (1987) Molecules controlling lymphocyte-endothelial interactions in lymph nodes are produced in vessels of inflamed synovium. Ann Rheum Dis 46(12):924-928

27. Freemont AJ (1983) A possible route for lymphocyte migration into diseased tissues. J Clin Pathol 36(2):161-166

28. Martinet L, Garrido I, Filleron T, Le Guellec S, Bellard E, Fournie JJ, Rochaix P, Girard JP (2011) Human solid tumors contain high endothelial venules: association with T- and B-lymphocyte infiltration and favorable prognosis in breast cancer. Cancer Res 71(17):5678-5687

29. Martinet L, Le Guellec S, Filleron T, Lamant L, Meyer N, Rochaix P, Garrido I, Girard JP (2012) High endothelial venules (HEVs) in human melanoma lesions: major gateways for tumorinfiltrating lymphocytes. OncoImmunology 1(6):829-839

30. Freemont AJ (1982) The small blood vessels in areas of lymphocytic infiltration around malignant neoplasms. Br J Cancer 46(2):283-288

31. Fukuyama S, Hiroi T, Yokota Y, Rennert PD, Yanagita M, Kinoshita N, Terawaki S, Shikina T, Yamamoto M, Kurono Y, Kiyono H (2002) Initiation of NALT organogenesis is independent of the IL-7R, LTbetaR, and NIK signaling pathways but requires the Id 2 gene and CD3(-)CD4(+)CD45(+) cells. Immunity 17(1):31-40

32. Ohmichi Y, Hirakawa J, Imai Y, Fukuda M, Kawashima H (2011) Essential role of peripheral node addressin in lymphocyte homing to nasal-associated lymphoid tissues and allergic immune responses. J Exp Med 208(5):1015-1025

33. Ying X, Chan K, Shenoy P, Hill M, Ruddle NH (2005) Lymphotoxin plays a crucial role in the development and function of nasal-associated lymphoid tissue through regulation of chemokines and peripheral node addressin. Am J Pathol 166(1):135-146
34. Nagatake T, Fukuyama S, Kim DY, Goda K, Igarashi O, Sato S, Nochi T, Sagara H, Yokota Y, Jetten AM, Kaisho T, Akira S, Mimuro H, Sasakawa C, Fukui Y, Fujihashi K, Akiyama T, Inoue J, Penninger JM, Kunisawa J, Kiyono H (2009) Id2-, RORgammat-, and LTbetaR-independent initiation of lymphoid organogenesis in ocular immunity. J Exp Med 206(11):2351-2364

35. Fenton TM, Jorgensen PB, Niss K, Rubin SJS, Morbe UM, Riis LB, Da Silva C, Plumb A, Vandamme J, Jakobsen HL, Brunak S, Habtezion A, Nielsen OH, Johansson-Lindbom B, Agace WW (2020) Immune profiling of human gut-associated lymphoid tissue identifies a role for isolated lymphoid follicles in priming of region-specific immunity. Immunity 52(3):557-570 e556

36. Elewa YHA, Ichii O, Takada K, Nakamura T, Masum MA, Kon Y (2018) Histopathological correlations between mediastinal fat-associated lymphoid clusters and the development of lung inflammation and fibrosis following bleomycin administration in mice. Front Immunol 9:271

37. Rangel-Moreno J, Moyron-Quiroz JE, Carragher DM, Kusser K, Hartson L, Moquin A, Randall TD (2009) Omental milky spots develop in the absence of lymphoid tissue-inducer cells and support B and T cell responses to peritoneal antigens. Immunity 30(5):731-743

38. Buscher K, Wang H, Zhang X, Striewski P, Wirth B, Saggu G, Lutke-Enking S, Mayadas TN, Ley K, Sorokin L, Song J (2016) Protection from septic peritonitis by rapid neutrophil recruitment through omental high endothelial venules. Nat Commun 7:10828

39. Streeter PR, Berg EL, Rouse BT, Bargatze RF, Butcher EC (1988) A tissue-specific endothelial cell molecule involved in lymphocyte homing. Nature 331(6151):41-46

40. Lee M, Kiefel H, LaJevic MD, Macauley MS, O'Hara E, Pan J, Paulson JC, Butcher EC (2014) Transcriptional programs of lymphoid tissue capillary and high endothelium reveal control mechanisms for lymphocyte homing. Nat Immunol 15:982-995

41. Baumhueter S, Singer MS, Henzel W, Hemmerich S, Renz M, Rosen SD, Lasky LA (1993) Binding of L-selectin to the vascular sialomucin CD34. Science 262(5132):436-438

42. Baumhueter S, Dybdal N, Kyle C, Lasky LA (1994) Global vascular expression of murine CD34, a sialomucin-like endothelial ligand for L-selectin. Blood 84(8):2554-2565

43. Arata-Kawai H, Singer MS, Bistrup A, Zante A, Wang YQ, Ito Y, Bao X, Hemmerich S, Fukuda M, Rosen SD (2011) Functional contributions of $\mathrm{N}$ - and $\mathrm{O}$-glycans to $\mathrm{L}$-selectin ligands in murine and human lymphoid organs. Am J Pathol 178(1):423-433

44. Hirakawa J, Tsuboi K, Sato K, Kobayashi M, Watanabe S, Takakura A, Imai Y, Ito Y, Fukuda M, Kawashima H (2010) Novel anti-carbohydrate antibodies reveal the cooperative function of sulfated $\mathrm{N}$ - and O-glycans in lymphocyte homing. J Biol Chem 285(52):40864-40878

45. Yeh JC, Hiraoka N, Petryniak B, Nakayama J, Ellies LG, Rabuka D, Hindsgaul O, Marth JD, Lowe JB, Fukuda M (2001) Novel sulfated lymphocyte homing receptors and their control by a Core1 extension beta 1,3-N-acetylglucosaminyltransferase. Cell 105(7):957-969

46. Mitsuoka C, Sawada-Kasugai M, Ando-Furui K, Izawa M, Nakanishi H, Nakamura S, Ishida H, Kiso M, Kannagi R (1998) Identification of a major carbohydrate capping group of the L-selectin ligand on high endothelial venules in human lymph nodes as 6-sulfo sialyl Lewis X. J Biol Chem 273(18):11225-11233

47. Mitoma J, Bao X, Petryanik B, Schaerli P, Gauguet JM, Yu SY, Kawashima H, Saito H, Ohtsubo K, Marth JD, Khoo KH, von Andrian UH, Lowe JB, Fukuda M (2007) Critical functions of N-glycans in L-selectin-mediated lymphocyte homing and recruitment. Nat Immunol 8(4):409-418 
48. Uchimura K, Gauguet JM, Singer MS, Tsay D, Kannagi R, Muramatsu T, von Andrian UH, Rosen SD (2005) A major class of L-selectin ligands is eliminated in mice deficient in two sulfotransferases expressed in high endothelial venules. Nat Immunol 6(11):1105-1113

49. Kawashima H, Petryniak B, Hiraoka N, Mitoma J, Huckaby V, Nakayama J, Uchimura K, Kadomatsu K, Muramatsu T, Lowe JB, Fukuda M (2005) N-acetylglucosamine-6-O-sulfotransferases 1 and 2 cooperatively control lymphocyte homing through L-selectin ligand biosynthesis in high endothelial venules. Nat Immunol 6(11):1096-1104

50. Streeter PR, Rouse BT, Butcher EC (1988) Immunohistologic and functional characterization of a vascular addressin involved in lymphocyte homing into peripheral lymph nodes. J Cell Biol 107(5):1853-1862

51. Michie SA, Streeter PR, Bolt PA, Butcher EC, Picker LJ (1993) The human peripheral lymph node vascular addressin. An inducible endothelial antigen involved in lymphocyte homing. Am J Pathol 143(6):1688-1698

52. von Andrian UH (1996) Intravital microscopy of the peripheral lymph node microcirculation in mice. Microcirculation 3(3):287-300

53. Veerman K, Tardiveau C, Martins F, Coudert J, Girard JP (2019) Single-cell analysis reveals heterogeneity of high endothelial venules and different regulation of genes controlling lymphocyte entry to lymph nodes. Cell Rep 26(11):3116-3131 e3115

54. Brulois K, Rajaraman A, Szade A, Nordling S, Bogoslowski A, Dermadi D, Rahman M, Kiefel H, O'Hara E, Koning JJ, Kawashima H, Zhou B, Vestweber D, Red-Horse K, Mebius RE, Adams RH, Kubes P, Pan J, Butcher EC (2020) A molecular map of murine lymph node blood vascular endothelium at single cell resolution. Nat Commun 11(1):3798

55. Girard JP, Springer TA (1995) Cloning from purified high endothelial venule cells of hevin, a close relative of the antiadhesive extracellular matrix protein SPARC. Immunity 2(1):113-123

56. Girard JP, Baekkevold ES, Yamanaka T, Haraldsen G, Brandtzaeg P, Amalric F (1999) Heterogeneity of endothelial cells: the specialized phenotype of human high endothelial venules characterized by suppression subtractive hybridization. Am J Pathol 155(6):2043-2055

57. Palmeri D, Zuo FR, Rosen SD, Hemmerich S (2004) Differential gene expression profile of human tonsil high endothelial cells: implications for lymphocyte trafficking. J Leukoc Biol 75(5):910-927

58. Izawa D, Tanaka T, Saito K, Ogihara H, Usui T, Kawamoto S, Matsubara K, Okubo K, Miyasaka M (1999) Expression profile of active genes in mouse lymph node high endothelial cells. Int Immunol 11(12):1989-1998

59. Maly P, Thall A, Petryniak B, Rogers CE, Smith PL, Marks RM, Kelly RJ, Gersten KM, Cheng G, Saunders TL, Camper SA, Camphausen RT, Sullivan FX, Isogai Y, Hindsgaul O, von Andrian UH, Lowe JB (1996) The alpha(1,3)fucosyltransferase Fuc-TVII controls leukocyte trafficking through an essential role in L-, E-, and P-selectin ligand biosynthesis. Cell 86(4):643-653

60. Yang WH, Nussbaum C, Grewal PK, Marth JD, Sperandio M (2012) Coordinated roles of ST3Gal-VI and ST3Gal-IV sialyltransferases in the synthesis of selectin ligands. Blood 120(5):1015-1026

61. Kanda H, Newton R, Klein R, Morita Y, Gunn MD, Rosen SD (2008) Autotaxin, an ectoenzyme that produces lysophosphatidic acid, promotes the entry of lymphocytes into secondary lymphoid organs. Nat Immunol 9(4):415-423

62. Nakasaki T, Tanaka T, Okudaira S, Hirosawa M, Umemoto E, Otani K, Jin S, Bai Z, Hayasaka H, Fukui Y, Aozasa K, Fujita N, Tsuruo T, Ozono K, Aoki J, Miyasaka M (2008) Involvement of the lysophosphatidic acid-generating enzyme autotaxin in lymphocyte-endothelial cell interactions. Am J Pathol 173(5):1566-1576

63. Zhang Y, Chen YC, Krummel MF, Rosen SD (2012) Autotaxin through lysophosphatidic acid stimulates polarization, motility, and transendothelial migration of naive T cells. J Immunol 189(8):3914-3924

64. Hata E, Sasaki N, Takeda A, Tohya K, Umemoto E, Akahoshi N, Ishii S, Bando K, Abe T, Kano K, Aoki J, Hayasaka H, Miyasaka M (2016) Lysophosphatidic acid receptors LPA4 and LPA6 differentially promote lymphocyte transmigration across high endothelial venules in lymph nodes. Int Immunol 28(6):283-292

65. Simmons S, Sasaki N, Umemoto E, Uchida Y, Fukuhara S, Kitazawa Y, Okudaira M, Inoue A, Tohya K, Aoi K, Aoki J, Mochizuki N, Matsuno K, Takeda K, Miyasaka M, Ishii M (2019) High-endothelial cell-derived S1P regulates dendritic cell localization and vascular integrity in the lymph node. Elife 8:e41239

66. Warnock RA, Askari S, Butcher EC, von Andrian UH (1998) Molecular mechanisms of lymphocyte homing to peripheral lymph nodes. J Exp Med 187(2):205-216

67. Okada T, Ngo VN, Ekland EH, Forster R, Lipp M, Littman DR, Cyster JG (2002) Chemokine requirements for B cell entry to lymph nodes and Peyer's patches. J Exp Med 196(1):65-75

68. Gunn MD, Tangemann K, Tam C, Cyster JG, Rosen SD, Williams LT (1998) A chemokine expressed in lymphoid high endothelial venules promotes the adhesion and chemotaxis of naive T lymphocytes. Proc Natl Acad Sci USA 95(1):258-263

69. Ebisuno Y, Tanaka T, Kanemitsu N, Kanda H, Yamaguchi K, Kaisho T, Akira S, Miyasaka M (2003) Cutting edge: the B cell chemokine CXC chemokine ligand 13/B lymphocyte chemoattractant is expressed in the high endothelial venules of lymph nodes and Peyer's patches and affects B cell trafficking across high endothelial venules. J Immunol 171(4):1642-1646

70. Stein JV, Rot A, Luo Y, Narasimhaswamy M, Nakano H, Gunn MD, Matsuzawa A, Quackenbush EJ, Dorf ME, von Andrian UH (2000) The CC chemokine thymus-derived chemotactic agent 4 (TCA-4, secondary lymphoid tissue chemokine, 6Ckine, exodus-2) triggers lymphocyte function-associated antigen 1-mediated arrest of rolling $\mathrm{T}$ lymphocytes in peripheral lymph node high endothelial venules. J Exp Med 191(1):61-76

71. Scimone ML, Felbinger TW, Mazo IB, Stein JV, Von Andrian UH, Weninger W (2004) CXCL12 mediates CCR7-independent homing of central memory cells, but not naive T cells, in peripheral lymph nodes. J Exp Med 199(8):1113-1120

72. Forster R, Davalos-Misslitz AC, Rot A (2008) CCR7 and its ligands: balancing immunity and tolerance. Nat Rev Immunol $8(5): 362-371$

73. Stein JV, Nombela-Arrieta C (2005) Chemokine control of lymphocyte trafficking: a general overview. Immunology 116(1):1-12

74. Carlsen HS, Haraldsen G, Brandtzaeg P, Baekkevold ES (2005) Disparate lymphoid chemokine expression in mice and men: no evidence of CCL21 synthesis by human high endothelial venules. Blood 106(2):444-446

75. Baekkevold ES, Yamanaka T, Palframan RT, Carlsen HS, Reinholt FP, von Andrian UH, Brandtzaeg P, Haraldsen G (2001) The CCR7 ligand elc (CCL19) is transcytosed in high endothelial venules and mediates T cell recruitment. J Exp Med 193(9):1105-1112

76. Berlin C, Berg EL, Briskin MJ, Andrew DP, Kilshaw PJ, Holzmann B, Weissman IL, Hamann A, Butcher EC (1993) Alpha 4 beta 7 integrin mediates lymphocyte binding to the mucosal vascular addressin MAdCAM-1. Cell 74(1):185-185

77. Shamri R, Grabovsky V, Gauguet JM, Feigelson S, Manevich E, Kolanus W, Robinson MK, Staunton DE, von Andrian UH, Alon $R$ (2005) Lymphocyte arrest requires instantaneous induction 
of an extended LFA-1 conformation mediated by endotheliumbound chemokines. Nat Immunol 6(5):497-506

78. Bajenoff M, Egen JG, Koo LY, Laugier JP, Brau F, Glaichenhaus N, Germain RN (2006) Stromal cell networks regulate lymphocyte entry, migration, and territoriality in lymph nodes. Immunity 25(6):989-1001

79. Schoefl GI (1972) The migration of lymphocytes across the vascular endothelium in lymphoid tissue. A reexamination. J Exp Med 136(3):568-588

80. Park EJ, Peixoto A, Imai Y, Goodarzi A, Cheng G, Carman CV, von Andrian UH, Shimaoka M (2010) Distinct roles for LFA-1 affinity regulation during T-cell adhesion, diapedesis, and interstitial migration in lymph nodes. Blood 115(8):1572-1581

81. Park C, Hwang IY, Sinha RK, Kamenyeva O, Davis MD, Kehrl JH (2012) Lymph node B lymphocyte trafficking is constrained by anatomy and highly dependent upon chemoattractant desensitization. Blood 119(4):978-989

82. Boscacci RT, Pfeiffer F, Gollmer K, Sevilla AI, Martin AM, Soriano SF, Natale D, Henrickson S, von Andrian UH, Fukui Y, Mellado M, Deutsch U, Engelhardt B, Stein JV (2010) Comprehensive analysis of lymph node stroma-expressed Ig superfamily members reveals redundant and nonredundant roles for ICAM-1, ICAM-2, and VCAM-1 in lymphocyte homing. Blood 116(6):915-925

83. Yan SLS, Hwang IY, Kamenyeva O, Kehrl JH (2019) In vivo F-actin filament organization during lymphocyte transendothelial and interstitial migration revealed by intravital microscopy. iScience 16:283-297

84. Mionnet C, Sanos SL, Mondor I, Jorquera A, Laugier JP, Germain RN, Bajenoff M (2011) High endothelial venules as traffic control points maintaining lymphocyte population homeostasis in lymph nodes. Blood 118(23):6115-6122

85. Vestweber D (2015) How leukocytes cross the vascular endothelium. Nat Rev Immunol 15(11):692-704

86. Muller WA (2011) Mechanisms of leukocyte transendothelial migration. Annu Rev Pathol 6:323-344

87. Hendriks HR, Eestermans IL (1983) Disappearance and reappearance of high endothelial venules and immigrating lymphocytes in lymph nodes deprived of afferent lymphatic vessels: a possible regulatory role of macrophages in lymphocyte migration. Eur J Immunol 13(8):663-669

88. Hendriks HR, Duijvestijn AM, Kraal G (1987) Rapid decrease in lymphocyte adherence to high endothelial venules in lymph nodes deprived of afferent lymphatic vessels. Eur J Immunol 17(12):1691-1695

89. Mebius RE, Streeter PR, Breve J, Duijvestijn AM, Kraal G (1991) The influence of afferent lymphatic vessel interruption on vascular addressin expression. J Cell Biol 115(1):85-95

90. Mebius RE, Dowbenko D, Williams A, Fennie C, Lasky LA, Watson SR (1993) Expression of GlyCAM-1, an endothelial ligand for L-selectin, is affected by afferent lymphatic flow. $\mathrm{J}$ Immunol 151(12):6769-6776

91. Gretz JE, Norbury CC, Anderson AO, Proudfoot AE, Shaw S (2000) Lymph-borne chemokines and other low molecular weight molecules reach high endothelial venules via specialized conduits while a functional barrier limits access to the lymphocyte microenvironments in lymph node cortex. J Exp Med 192(10):1425-1440

92. Palframan RT, Jung S, Cheng G, Weninger W, Luo Y, Dorf M, Littman DR, Rollins BJ, Zweerink H, Rot A, von Andrian UH (2001) Inflammatory chemokine transport and presentation in HEV: a remote control mechanism for monocyte recruitment to lymph nodes in inflamed tissues. J Exp Med 194(9):1361-1373

93. Lacorre DA, Baekkevold ES, Garrido I, Brandtzaeg P, Haraldsen G, Amalric F, Girard JP (2004) Plasticity of endothelial cells: rapid dedifferentiation of freshly isolated high endothelial venule endothelial cells outside the lymphoid tissue microenvironment. Blood 103(11):4164-4172

94. Moussion C, Girard JP (2011) Dendritic cells control lymphocyte entry to lymph nodes through high endothelial venules. Nature 479:542-546

95. Mebius RE, Streeter PR, Michie S, Butcher EC, Weissman IL (1996) A developmental switch in lymphocyte homing receptor and endothelial vascular addressin expression regulates lymphocyte homing and permits CD4+ CD3- cells to colonize lymph nodes. Proc Natl Acad Sci USA 93(20):11019-11024

96. Wendland M, Willenzon S, Kocks J, Davalos-Misslitz AC, Hammerschmidt SI, Schumann K, Kremmer E, Sixt M, Hoffmeyer A, Pabst O, Forster R (2011) Lymph node T cell homeostasis relies on steady state homing of dendritic cells. Immunity 35(6):945-957

97. Zhang Z, Li J, Zheng W, Zhao G, Zhang H, Wang X, Guo Y, Qin C, Shi Y (2016) Peripheral lymphoid volume expansion and maintenance are controlled by gut microbiota via RALDH+ dendritic cells. Immunity 44(2):330-342

98. Webster B, Ekland EH, Agle LM, Chyou S, Ruggieri R, Lu TT (2006) Regulation of lymph node vascular growth by dendritic cells. J Exp Med 203(8):1903-1913

99. Browning JL, Allaire N, Ngam-Ek A, Notidis E, Hunt J, Perrin S, Fava RA (2005) Lymphotoxin-beta receptor signaling is required for the homeostatic control of HEV differentiation and function. Immunity 23(5):539-550

100. Carragher D, Johal R, Button A, White A, Eliopoulos A, Jenkinson E, Anderson G, Caamano J (2004) A stromaderived defect in NF-kappaB2-/- mice causes impaired lymph node development and lymphocyte recruitment. J Immunol 173(4):2271-2279

101. Drayton DL, Bonizzi G, Ying X, Liao S, Karin M, Ruddle NH (2004) I kappa B kinase complex alpha kinase activity controls chemokine and high endothelial venule gene expression in lymph nodes and nasal-associated lymphoid tissue. J Immunol 173(10):6161-6168

102. Onder L, Danuser R, Scandella E, Firner S, Chai Q, Hehlgans T, Stein JV, Ludewig B (2013) Endothelial cell-specific lymphotoxin-beta receptor signaling is critical for lymph node and high endothelial venule formation. J Exp Med 210(3):465-473

103. Liao S, Ruddle NH (2006) Synchrony of high endothelial venules and lymphatic vessels revealed by immunization. J Immunol 177(5):3369-3379

104. Sun SC (2017) The non-canonical NF-kappaB pathway in immunity and inflammation. Nat Rev Immunol 17(9):545-558

105. Bajenoff M, Granjeaud S, Guerder S (2003) The strategy of T cell antigen-presenting cell encounter in antigen-draining lymph nodes revealed by imaging of initial T cell activation. J Exp Med 198(5):715-724

106. Mempel TR, Henrickson SE, Von Andrian UH (2004) T-cell priming by dendritic cells in lymph nodes occurs in three distinct phases. Nature 427(6970):154-159

107. Stoltzfus CR, Filipek J, Gern BH, Olin BE, Leal JM, Wu Y, Lyons-Cohen MR, Huang JY, Paz-Stoltzfus CL, Plumlee CR, Poschinger T, Urdahl KB, Perro M, Gerner MY (2020) CytoMAP: a spatial analysis toolbox reveals features of myeloid cell organization in lymphoid tissues. Cell Rep 31(3):107523

108. Junt T, Scandella E, Ludewig B (2008) Form follows function: lymphoid tissue microarchitecture in antimicrobial immune defence. Nat Rev Immunol 8(10):764-775

109. Krishnamurty AT, Turley SJ (2020) Lymph node stromal cells: cartographers of the immune system. Nat Immunol 21(4):369-380

110. Thierry GR, Gentek R, Bajenoff M (2019) Remodeling of reactive lymph nodes: dynamics of stromal cells and underlying chemokine signaling. Immunol Rev 289(1):42-61 
111. Kumar V, Chyou S, Stein JV, Lu TT (2012) Optical projection tomography reveals dynamics of HEV growth after immunization with protein plus CFA and features shared with HEVs in acute autoinflammatory lymphadenopathy. Front Immunol 3:282

112. Mondor I, Jorquera A, Sene C, Adriouch S, Adams RH, Zhou B, Wienert S, Klauschen F, Bajenoff M (2016) Clonal proliferation and stochastic pruning orchestrate lymph node vasculature remodeling. Immunity 45(4):877-888

113. Soderberg KA, Payne GW, Sato A, Medzhitov R, Segal SS, Iwasaki A (2005) Innate control of adaptive immunity via remodeling of lymph node feed arteriole. Proc Natl Acad Sci USA 102(45):16315-16320

114. Sawada J, Perrot CY, Chen L, Fournier-Goss AE, Oyer J, Copik A, Komatsu M (2021) High endothelial venules accelerate naive $\mathrm{T}$ cell recruitment by tumor necrosis factor-mediated R-Ras upregulation. Am J Pathol 191(2):396-414

115. Angeli V, Ginhoux F, Llodra J, Quemeneur L, Frenette PS, Skobe M, Jessberger R, Merad M, Randolph GJ (2006) B cell-driven lymphangiogenesis in inflamed lymph nodes enhances dendritic cell mobilization. Immunity 24(2):203-215

116. Tzeng TC, Chyou S, Tian S, Webster B, Carpenter AC, Guaiquil VH, Lu TT (2010) CD11c(hi) dendritic cells regulate the re-establishment of vascular quiescence and stabilization after immune stimulation of lymph nodes. J Immunol 184(8):4247-4257

117. Kumar V, Scandella E, Danuser R, Onder L, Nitschke M, Fukui Y, Halin C, Ludewig B, Stein JV (2010) Global lymphoid tissue remodeling during a viral infection is orchestrated by a B celllymphotoxin-dependent pathway. Blood 115(23):4725-4733

118. Chyou S, Benahmed F, Chen J, Kumar V, Tian S, Lipp M, Lu TT (2011) Coordinated regulation of lymph node vascular-stromal growth first by CD11c+ cells and then by T and B cells. J Immunol 187(11):5558-5567

119. Shrestha B, Hashiguchi T, Ito T, Miura N, Takenouchi K, Oyama Y, Kawahara K, Tancharoen S, Ki IY, Arimura N, Yoshinaga N, Noma S, Shrestha C, Nitanda T, Kitajima S, Arimura K, Sato M, Sakamoto T, Maruyama I (2010) B cell-derived vascular endothelial growth factor A promotes lymphangiogenesis and high endothelial venule expansion in lymph nodes. J Immunol 184(9):4819-4826

120. Hoke D, Mebius RE, Dybdal N, Dowbenko D, Gribling P, Kyle C, Baumhueter S, Watson SR (1995) Selective modulation of the expression of L-selectin ligands by an immune response. Curr Biol 5(6):670-678

121. Janatpour MJ, Hudak S, Sathe M, Sedgwick JD, McEvoy LM (2001) Tumor necrosis factor-dependent segmental control of MIG expression by high endothelial venules in inflamed lymph nodes regulates monocyte recruitment. J Exp Med 194(9):1375-1384

122. Martin-Fontecha A, Baumjohann D, Guarda G, Reboldi A, Hons M, Lanzavecchia A, Sallusto F (2008) CD40L+ CD4+ memory $\mathrm{T}$ cells migrate in a CD62P-dependent fashion into reactive lymph nodes and license dendritic cells for $\mathrm{T}$ cell priming. $\mathrm{J}$ Exp Med 205(11):2561-2574

123. Swarte VV, Joziasse DH, Van den Eijnden DH, Petryniak B, Lowe JB, Kraal G, Mebius RE (1998) Regulation of fucosyltransferase-VII expression in peripheral lymph node high endothelial venules. Eur J Immunol 28(10):3040-3047

124. Yoneyama H, Matsuno K, Zhang Y, Nishiwaki T, Kitabatake M, Ueha S, Narumi S, Morikawa S, Ezaki T, Lu B, Gerard C, Ishikawa S, Matsushima K (2004) Evidence for recruitment of plasmacytoid dendritic cell precursors to inflamed lymph nodes through high endothelial venules. Int Immunol 16(7):915-928

125. Bogoslowski A, Butcher EC, Kubes P (2018) Neutrophils recruited through high endothelial venules of the lymph nodes via PNAd intercept disseminating Staphylococcus aureus. Proc Natl Acad Sci USA 115(10):2449-2454

126. Guarda G, Hons M, Soriano SF, Huang AY, Polley R, MartinFontecha A, Stein JV, Germain RN, Lanzavecchia A, Sallusto F (2007) L-selectin-negative CCR7- effector and memory CD8+ $\mathrm{T}$ cells enter reactive lymph nodes and kill dendritic cells. Nat Immunol 8(7):743-752

127. Kamenyeva O, Boularan C, Kabat J, Cheung GY, Cicala C, Yeh AJ, Chan JL, Periasamy S, Otto M, Kehrl JH (2015) Neutrophil recruitment to lymph nodes limits local humoral response to Staphylococcus aureus. PLoS Pathog 11(4):e1004827

128. Chen DS, Mellman I (2013) Oncology meets immunology: the cancer-immunity cycle. Immunity 39(1):1-10

129. Buchwald ZS, Nasti TH, Lee J, Eberhardt CS, Wieland A, Im SJ, Lawson D, Curran W, Ahmed R, Khan MK (2020) Tumordraining lymph node is important for a robust abscopal effect stimulated by radiotherapy. J Immunother Cancer 8(2):e000867

130. Fransen MF, Schoonderwoerd M, Knopf P, Camps MG, Hawinkels LJ, Kneilling M, van Hall T, Ossendorp F (2018) Tumordraining lymph nodes are pivotal in PD-1/PD-L1 checkpoint therapy. JCI Insight 3(23):e124507

131. Nathanson SD (2003) Insights into the mechanisms of lymph node metastasis. Cancer 98(2):413-423

132. Milutinovic S, Abe J, Godkin A, Stein JV, Gallimore A (2021) The dual role of high endothelial venules in cancer progression versus immunity. Trends Cancer 7(3):214-225

133. Carriere V, Colisson R, Jiguet-Jiglaire C, Bellard E, Bouche G, Al Saati T, Amalric F, Girard JP, M'Rini C (2005) Cancer cells regulate lymphocyte recruitment and leukocyte-endothelium interactions in the tumor-draining lymph node. Cancer Res 65(24):11639-11648

134. Qian CN, Berghuis B, Tsarfaty G, Bruch M, Kort EJ, Ditlev J, Tsarfaty I, Hudson E, Jackson DG, Petillo D, Chen J, Resau JH, Teh BT (2006) Preparing the "soil": the primary tumor induces vasculature reorganization in the sentinel lymph node before the arrival of metastatic cancer cells. Cancer Res 66(21):10365-10376

135. Lee SY, Chao-Nan Q, Seng OA, Peiyi C, Bernice WH, Swe MS, Chii WJ, Jacqueline HS, Chee SK (2012) Changes in specialized blood vessels in lymph nodes and their role in cancer metastasis. J Transl Med 10:206

136. Bekkhus T, Martikainen T, Olofsson A, Franzen Boger M, Vasiliu Bacovia D, Warnberg F, Ulvmar MH (2021) Remodeling of the lymph node high endothelial venules reflects tumor invasiveness in breast cancer and is associated with dysregulation of perivascular stromal cells. Cancers (Basel) 13(2):211

137. Chung MK, Do IG, Jung E, Son YI, Jeong HS, Baek CH (2012) Lymphatic vessels and high endothelial venules are increased in the sentinel lymph nodes of patients with oral squamous cell carcinoma before the arrival of tumor cells. Ann Surg Oncol 19(5):1595-1601

138. Shen H, Wang X, Shao Z, Liu K, Xia XY, Zhang HZ, Song K, Song Y, Shang ZJ (2014) Alterations of high endothelial venules in primary and metastatic tumors are correlated with lymph node metastasis of oral and pharyngeal carcinoma. Cancer Biol Ther 15(3):342-349

139. Herzog BH, Fu J, Wilson SJ, Hess PR, Sen A, McDaniel JM, Pan Y, Sheng M, Yago T, Silasi-Mansat R, McGee S, May F, Nieswandt B, Morris AJ, Lupu F, Coughlin SR, McEver RP, Chen H, Kahn ML, Xia L (2013) Podoplanin maintains high endothelial venule integrity by interacting with platelet CLEC2. Nature 502(7469):105-109

140. Qian CN, Resau JH, Teh BT (2007) Prospects for vasculature reorganization in sentinel lymph nodes. Cell Cycle 6(5):514-517 
141. Brown M, Assen FP, Leithner A, Abe J, Schachner H, Asfour G, Bago-Horvath Z, Stein JV, Uhrin P, Sixt M, Kerjaschki D (2018) Lymph node blood vessels provide exit routes for metastatic tumor cell dissemination in mice. Science 359(6382):1408-1411

142. Pereira ER, Kedrin D, Seano G, Gautier O, Meijer EFJ, Jones D, Chin SM, Kitahara S, Bouta EM, Chang J, Beech E, Jeong HS, Carroll MC, Taghian AG, Padera TP (2018) Lymph node metastases can invade local blood vessels, exit the node, and colonize distant organs in mice. Science 359(6382):1403-1407

143. Medzhitov R (2008) Origin and physiological roles of inflammation. Nature 454(7203):428-435

144. Buckley CD, Barone F, Nayar S, Benezech C, Caamano J (2015) Stromal cells in chronic inflammation and tertiary lymphoid organ formation. Annu Rev Immunol 33:715-745

145. Girard JP (2007) High-endothelial venule-like vessels in human chronic inflammatory diseases. In: Aird W (ed) Endothelial biomedicine. Cambridge University Press, Cambridge, pp $1419-1430$

146. Sakai Y, Kobayashi M (2015) Lymphocyte "homing" and chronic inflammation. Pathol Int 65(7):344-354

147. Drayton DL, Liao S, Mounzer RH, Ruddle NH (2006) Lymphoid organ development: from ontogeny to neogenesis. Nat Immunol 7(4):344-353

148. Aloisi F, Pujol-Borrell R (2006) Lymphoid neogenesis in chronic inflammatory diseases. Nat Rev Immunol 6(3):205-217

149. Toppila S, Paavonen T, Laitinen A, Laitinen LA, Renkonen R (2000) Endothelial sulfated sialyl Lewis x glycans, putative L-selectin ligands, are preferentially expressed in bronchial asthma but not in other chronic inflammatory lung diseases. Am J Respir Cell Mol Biol 23(4):492-498

150. Rosen SD, Tsay D, Singer MS, Hemmerich S, Abraham WM (2005) Therapeutic targeting of endothelial ligands for L-selectin (PNAd) in a sheep model of asthma. Am J Pathol 166(3):935-944

151. Jahnsen FL, Lund-Johansen F, Dunne JF, Farkas L, Haye R, Brandtzaeg P (2000) Experimentally induced recruitment of plasmacytoid (CD123high) dendritic cells in human nasal allergy. J Immunol 165(7):4062-4068

152. Middleton J, Americh L, Gayon R, Julien D, Mansat M, Mansat P, Anract P, Cantagrel A, Cattan P, Reimund JM, Aguilar L, Amalric F, Girard JP (2005) A comparative study of endothelial cell markers expressed in chronically inflamed human tissues: MECA-79, Duffy antigen receptor for chemokines, von Willebrand factor, CD31, CD34, CD105 and CD146. J Pathol 206(3):260-268

153. Canete JD, Celis R, Moll C, Izquierdo E, Marsal S, Sanmarti R, Palacin A, Lora D, de la Cruz J, Pablos JL (2009) Clinical significance of synovial lymphoid neogenesis and its reversal after anti-tumour necrosis factor alpha therapy in rheumatoid arthritis. Ann Rheum Dis 68(5):751-756

154. Pablos JL, Santiago B, Tsay D, Singer MS, Palao G, Galindo M, Rosen SD (2005) A HEV-restricted sulfotransferase is expressed in rheumatoid arthritis synovium and is induced by lymphotoxinalpha/beta and TNF-alpha in cultured endothelial cells. BMC Immunol 6(1):6

155. Manzo A, Bugatti S, Caporali R, Prevo R, Jackson DG, Uguccioni M, Buckley CD, Montecucco C, Pitzalis C (2007) CCL21 expression pattern of human secondary lymphoid organ stroma is conserved in inflammatory lesions with lymphoid neogenesis. Am J Pathol 171(5):1549-1562

156. Manzo A, Paoletti S, Carulli M, Blades MC, Barone F, Yanni G, Fitzgerald O, Bresnihan B, Caporali R, Montecucco C, Uguccioni M, Pitzalis C (2005) Systematic microanatomical analysis of CXCL13 and CCL21 in situ production and progressive lymphoid organization in rheumatoid synovitis. Eur J Immunol 35(5):1347-1359
157. Renkonen J, Tynninen O, Hayry P, Paavonen T, Renkonen R (2002) Glycosylation might provide endothelial zip codes for organ-specific leukocyte traffic into inflammatory sites. Am J Pathol 161(2):543-550

158. Suzawa K, Kobayashi M, Sakai Y, Hoshino H, Watanabe M, Harada O, Ohtani H, Fukuda M, Nakayama J (2007) Preferential induction of peripheral lymph node addressin on high endothelial venule-like vessels in the active phase of ulcerative colitis. Am J Gastroenterol 102(7):1499-1509

159. Horjus Talabur Horje CS, Smids C, Meijer JW, Groenen MJ, Rijnders MK, van Lochem EG, Wahab PJ (2017) High endothelial venules associated with $\mathrm{T}$ cell subsets in the inflamed gut of newly diagnosed inflammatory bowel disease patients. Clin Exp Immunol 188(1):163-173

160. Salmi M, Granfors K, MacDermott R, Jalkanen S (1994) Aberrant binding of lamina propria lymphocytes to vascular endothelium in inflammatory bowel diseases. Gastroenterology 106(3):596-605

161. Kobayashi M, Hoshino H, Masumoto J, Fukushima M, Suzawa K, Kageyama S, Suzuki M, Ohtani H, Fukuda M, Nakayama J (2009) GlcNAc6ST-1-mediated decoration of MAdCAM-1 protein with L-selectin ligand carbohydrates directs disease activity of ulcerative colitis. Inflamm Bowel Dis 15(5):697-706

162. Weninger W, Carlsen HS, Goodarzi M, Moazed F, Crowley MA, Baekkevold ES, Cavanagh LL, von Andrian UH (2003) Naive T cell recruitment to nonlymphoid tissues: a role for endotheliumexpressed CC chemokine ligand 21 in autoimmune disease and lymphoid neogenesis. J Immunol 170(9):4638-4648

163. Salmi M, Rajala P, Jalkanen S (1997) Homing of mucosal leukocytes to joints. Distinct endothelial ligands in synovium mediate leukocyte-subtype specific adhesion. J Clin Invest 99(9):2165-2172

164. Kaaij MH, Helder B, van Mens LJJ, van de Sande MGH, Baeten DLP, Tas SW (2020) Anti-IL-17A treatment reduces serum inflammatory, angiogenic and tissue remodeling biomarkers accompanied by less synovial high endothelial venules in peripheral spondyloarthritis. Sci Rep 10(1):21094

165. Yoshida H, Imamura Y, Yoshimura H, Kobayashi M (2020) Induction of high endothelial venule-like vessels in oral and cutaneous lichen planus: a comparative study. J Histochem Cytochem 68(5):343-350

166. Farkas L, Beiske K, Lund-Johansen F, Brandtzaeg P, Jahnsen FL (2001) Plasmacytoid dendritic cells (natural interferon- alpha/ beta-producing cells) accumulate in cutaneous lupus erythematosus lesions. Am J Pathol 159(1):237-243

167. Kirveskari J, Helinto M, Moilanen JA, Paavonen T, Tervo TM, Renkonen R (2002) Hydrocortisone reduced in vivo, inflammation-induced slow rolling of leukocytes and their extravasation into human conjunctiva. Blood 100(6):2203-2207

168. Toppila-Salmi SK, Myller JP, Torkkeli TV, Muhonen JV, Renkonen JA, Rautiainen ME, Renkonen RL (2005) Endothelial L-selectin ligands in sinus mucosa during chronic maxillary rhinosinusitis. Am J Respir Crit Care Med 171(12):1350-1357

169. Tsutsumiuchi T, Hoshino H, Fujieda S, Kobayashi M (2019) Induction of peripheral lymph node addressin in human nasal mucosa with eosinophilic chronic rhinosinusitis. Pathology 51(3):268-273

170. Barone F, Bombardieri M, Manzo A, Blades MC, Morgan PR, Challacombe SJ, Valesini G, Pitzalis C (2005) Association of CXCL13 and CCL21 expression with the progressive organization of lymphoid-like structures in Sjogren's syndrome. Arthritis Rheum 52(6):1773-1784

171. Aqrawi LA, Jensen JL, Fromreide S, Galtung HK, Skarstein K (2020) Expression of NGAL-specific cells and mRNA levels correlate with inflammation in the salivary gland, and its 
overexpression in the saliva, of patients with primary Sjogren's syndrome. Autoimmunity 53(6):333-343

172. Maruyama M, Kobayashi M, Sakai Y, Hiraoka N, Ohya A, Kageyama S, Tanaka E, Nakayama J, Morohoshi T (2013) Periductal induction of high endothelial venule-like vessels in type 1 autoimmune pancreatitis. Pancreas 42(1):53-59

173. De Bleecker JL, Engel AG, Butcher EC (1996) Peripheral lymphoid tissue-like adhesion molecule expression in nodular infiltrates in inflammatory myopathies. Neuromuscul Disord 6(4):255-260

174. Collett C, Munro JM (1999) Selective induction of endothelial L-selectin ligand in human lung inflammation. Histochem $\mathbf{J}$ 31(4):213-219

175. Perros F, Dorfmuller P, Montani D, Hammad H, Waelput W, Girerd B, Raymond N, Mercier O, Mussot S, Cohen-Kaminsky S, Humbert M, Lambrecht BN (2012) Pulmonary lymphoid neogenesis in idiopathic pulmonary arterial hypertension. Am J Respir Crit Care Med 185(3):311-321

176. Takaeda M, Yokoyama H, Segawa-Takaeda C, Wada T, Kobayashi K (2002) High endothelial venule-like vessels in the interstitial lesions of human glomerulonephritis. Am J Nephrol 22(1):48-57

177. Toppila S, Paavonen T, Nieminen MS, Hayry P, Renkonen R (1999) Endothelial L-selectin ligands are likely to recruit lymphocytes into rejecting human heart transplants. Am J Pathol 155(4):1303-1310

178. Di Carlo E, D’Antuono T, Contento S, Di Nicola M, Ballone E, Sorrentino C (2007) Quilty effect has the features of lymphoid neogenesis and shares CXCL13-CXCR5 pathway with recurrent acute cardiac rejections. Am J Transplant 7(1):201-210

179. Kirveskari J, Paavonen T, Hayry P, Renkonen R (2000) De novo induction of endothelial L-selectin ligands during kidney allograft rejection. J Am Soc Nephrol 11(12):2358-2365

180. Thaunat O, Patey N, Caligiuri G, Gautreau C, Mamani-Matsuda M, Mekki Y, Dieu-Nosjean MC, Eberl G, Ecochard R, Michel JB, Graff-Dubois S, Nicoletti A (2010) Chronic rejection triggers the development of an aggressive intragraft immune response through recapitulation of lymphoid organogenesis. J Immunol 185(1):717-728

181. Sato M, Hirayama S, Hwang DM, Lara-Guerra H, Wagnetz D, Waddell TK, Liu M, Keshavjee S (2009) The role of intrapulmonary de novo lymphoid tissue in obliterative bronchiolitis after lung transplantation. J Immunol 182(11):7307-7316

182. Ohya A, Kobayashi M, Sakai Y, Kawashima H, Kageyama S, Nakayama J (2013) Lymphocyte recruitment via high endothelial venules in lymphoid stroma of Warthin's tumour. Pathology 45(2):150-154

183. Inamura $S$, Shinagawa $T$, Hoshino H, Sakai $Y$, Imamura $Y$, Yokoyama O, Kobayashi M (2017) Appearance of high endothelial venule-like vessels in benign prostatic hyperplasia is associated with lower urinary tract symptoms. Prostate 77(7):794-802

184. Fernandez-Flores A, Suarez Penaranda JM, De Toro G, Alvarez Cuesta CC, Fernandez-Figueras MT, Kempf W, Monteagudo C (2018) Expression of peripheral node addressins by plasmacytic plaque of children, APACHE, TRAPP, and primary cutaneous angioplasmacellular hyperplasia. Appl Immunohistochem Mol Morphol 26(6):411-419

185. Windsperger K, Vondra S, Lackner AI, Kunihs V, Haslinger P, Meinhardt G, Dietrich B, Dekan S, Fiala C, Knofler M, Saleh L, Pollheimer J (2020) Densities of decidual high endothelial venules correlate with T-cell influx in healthy pregnancies and idiopathic recurrent pregnancy losses. Hum Reprod 35(11):2467-2477

186. Thiriot A, Perdomo C, Cheng G, Novitzky-Basso I, McArdle S, Kishimoto JK, Barreiro O, Mazo I, Triboulet R, Ley K, Rot
A, von Andrian UH (2017) Differential DARC/ACKR1 expression distinguishes venular from non-venular endothelial cells in murine tissues. BMC Biol 15(1):45

187. Briskin M, Winsor-Hines D, Shyjan A, Cochran N, Bloom S, Wilson J, McEvoy LM, Butcher EC, Kassam N, Mackay CR, Newman W, Ringler DJ (1997) Human mucosal addressin cell adhesion molecule-1 is preferentially expressed in intestinal tract and associated lymphoid tissue. Am J Pathol 151(1):97-110

188. Michie SA, Streeter PR, Butcher EC, Rouse RV (1995) L-selectin and alpha 4 beta 7 integrin homing receptor pathways mediate peripheral lymphocyte traffic to AKR mouse hyperplastic thymus. Am J Pathol 147(2):412-421

189. Mikulowska-Mennis A, Xu B, Berberian JM, Michie SA (2001) Lymphocyte migration to inflamed lacrimal glands is mediated by vascular cell adhesion molecule-1/alpha(4)beta(1) integrin, peripheral node addressin/l-selectin, and lymphocyte function-associated antigen-1 adhesion pathways. Am J Pathol 159(2):671-681

190. Xu B, Wagner N, Pham LN, Magno V, Shan Z, Butcher EC, Michie SA (2003) Lymphocyte homing to bronchus-associated lymphoid tissue (BALT) is mediated by L-selectin/PNAd, alpha4beta1 integrin/VCAM-1, and LFA-1 adhesion pathways. J Exp Med 197(10):1255-1267

191. Bistrup A, Tsay D, Shenoy P, Singer MS, Bangia N, Luther SA, Cyster JG, Ruddle NH, Rosen SD (2004) Detection of a sulfotransferase (HEC-GlcNAc6ST) in high endothelial venules of lymph nodes and in high endothelial venule-like vessels within ectopic lymphoid aggregates: relationship to the MECA-79 epitope. Am J Pathol 164(5):1635-1644

192. Faveeuw C, Gagnerault MC, Lepault F (1994) Expression of homing and adhesion molecules in infiltrated islets of Langerhans and salivary glands of nonobese diabetic mice. J Immunol 152(12):5969-5978

193. Hanninen A, Taylor C, Streeter PR, Stark LS, Sarte JM, Shizuru JA, Simell O, Michie SA (1993) Vascular addressins are induced on islet vessels during insulitis in nonobese diabetic mice and are involved in lymphoid cell binding to islet endothelium. J Clin Invest 92(5):2509-2515

194. Gatumu MK, Skarstein K, Papandile A, Browning JL, Fava RA, Bolstad AI (2009) Blockade of lymphotoxin-beta receptor signaling reduces aspects of Sjogren's syndrome in salivary glands of non-obese diabetic mice. Arthritis Res Ther 11(1):R24

195. Fava RA, Kennedy SM, Wood SG, Bolstad AI, Bienkowska J, Papandile A, Kelly JA, Mavragani CP, Gatumu M, Skarstein K, Browning JL (2011) Lymphotoxin-beta receptor blockade reduces CXCL13 in lacrimal glands and improves corneal integrity in the NOD model of Sjogren's syndrome. Arthritis Res Ther 13(6):R182

196. Hiraoka N, Petryniak B, Nakayama J, Tsuboi S, Suzuki M, Yeh JC, Izawa D, Tanaka T, Miyasaka M, Lowe JB, Fukuda M (1999) A novel, high endothelial venule-specific sulfotransferase expresses 6-sulfo sialyl Lewis(x), an L-selectin ligand displayed by CD34. Immunity 11(1):79-89

197. Katakai T, Hara T, Sugai M, Gonda H, Shimizu A (2003) Th1biased tertiary lymphoid tissue supported by CXC chemokine ligand 13-producing stromal network in chronic lesions of autoimmune gastritis. J Immunol 171(8):4359-4368

198. Ludewig B, Odermatt B, Landmann S, Hengartner H, Zinkernagel RM (1998) Dendritic cells induce autoimmune diabetes and maintain disease via de novo formation of local lymphoid tissue. J Exp Med 188(8):1493-1501

199. Yang J, Rosen SD, Bendele P, Hemmerich S (2006) Induction of PNAd and $\mathrm{N}$-acetylglucosamine 6-O-sulfotransferases 1 and 2 in mouse collagen-induced arthritis. BMC Immunol 7:12 
200. Nacionales DC, Kelly KM, Lee PY, Zhuang H, Li Y, Weinstein JS, Sobel E, Kuroda Y, Akaogi J, Satoh M, Reeves WH (2006) Type I interferon production by tertiary lymphoid tissue developing in response to 2,6,10,14-tetramethyl-pentadecane (pristane). Am J Pathol 168(4):1227-1240

201. Grabner R, Lotzer K, Dopping S, Hildner M, Radke D, Beer M, Spanbroek R, Lippert B, Reardon CA, Getz GS, Fu YX, Hehlgans T, Mebius RE, van der Wall M, Kruspe D, Englert C, Lovas A, Hu D, Randolph GJ, Weih F, Habenicht AJ (2009) Lymphotoxin beta receptor signaling promotes tertiary lymphoid organogenesis in the aorta adventitia of aged ApoE-/- mice. J Exp Med 206(1):233-248

202. Rangel-Moreno J, Carragher DM, de la Luz G-H, Hwang JY, Kusser K, Hartson L, Kolls JK, Khader SA, Randall TD (2011) The development of inducible bronchus-associated lymphoid tissue depends on IL-17. Nat Immunol 12(7):639-646

203. Bombardieri M, Barone F, Lucchesi D, Nayar S, van den Berg WB, Proctor G, Buckley CD, Pitzalis C (2012) Inducible tertiary lymphoid structures, autoimmunity, and exocrine dysfunction in a novel model of salivary gland inflammation in C57BL/6 mice. J Immunol 189(7):3767-3776

204. Dorraji SE, Kanapathippillai P, Hovd AK, Stenersrod MR, Horvei KD, Ursvik A, Figenschau SL, Thiyagarajan D, Fenton CG, Pedersen HL, Fenton KA (2020) Kidney tertiary lymphoid structures in lupus nephritis develop into large interconnected networks and resemble lymph nodes in gene signature. Am J Pathol 190(11):2203-2225

205. Cupedo T, Jansen W, Kraal G, Mebius RE (2004) Induction of secondary and tertiary lymphoid structures in the skin. Immunity 21(5):655-667

206. Zhu G, Nemoto S, Mailloux AW, Perez-Villarroel P, Nakagawa R, Falahat R, Berglund AE, Mule JJ (2018) Induction of tertiary lymphoid structures with antitumor function by a lymph nodederived stromal cell line. Front Immunol 9:1609

207. Yoneyama H, Matsuno K, Zhang Y, Murai M, Itakura M, Ishikawa S, Hasegawa G, Naito M, Asakura H, Matsushima K (2001) Regulation by chemokines of circulating dendritic cell precursors, and the formation of portal tract-associated lymphoid tissue, in a granulomatous liver disease. J Exp Med 193(1):35-49

208. Shomer NH, Fox JG, Juedes AE, Ruddle NH (2003) Helicobacter-induced chronic active lymphoid aggregates have characteristics of tertiary lymphoid tissue. Infect Immun 71(6):3572-3577

209. Winter S, Loddenkemper C, Aebischer A, Rabel K, Hoffmann K, Meyer TF, Lipp M, Hopken UE (2010) The chemokine receptor CXCR5 is pivotal for ectopic mucosa-associated lymphoid tissue neogenesis in chronic Helicobacter pylori-induced inflammation. J Mol Med 88(11):1169-1180

210. Moyron-Quiroz JE, Rangel-Moreno J, Kusser K, Hartson L, Sprague F, Goodrich S, Woodland DL, Lund FE, Randall TD (2004) Role of inducible bronchus associated lymphoid tissue (iBALT) in respiratory immunity. Nat Med 10(9):927-934

211. Rangel-Moreno J, Moyron-Quiroz JE, Hartson L, Kusser K, Randall TD (2007) Pulmonary expression of CXC chemokine ligand 13, CC chemokine ligand 19, and CC chemokine ligand 21 is essential for local immunity to influenza. Proc Natl Acad Sci USA 104(25):10577-10582

212. Onrust SV, Hartl PM, Rosen SD, Hanahan D (1996) Modulation of L-selectin ligand expression during an immune response accompanying tumorigenesis in transgenic mice. J Clin Invest 97(1):54-64

213. Luther SA, Bidgol A, Hargreaves DC, Schmidt A, Xu Y, Paniyadi J, Matloubian M, Cyster JG (2002) Differing activities of homeostatic chemokines CCL19, CCL21, and CXCL12 in lymphocyte and dendritic cell recruitment and lymphoid neogenesis. J Immunol 169(1):424-433
214. Fan L, Reilly CR, Luo Y, Dorf ME, Lo D (2000) Ectopic expression of the chemokine TCA4/SLC is sufficient to trigger lymphoid neogenesis. J Immunol 164:3955-3959

215. Chen SC, Vassileva G, Kinsley D, Holzmann S, Manfra D, Wiekowski MT, Romani N, Lira SA (2002) Ectopic expression of the murine chemokines CCL21a and CCL21b induces the formation of lymph node-like structures in pancreas, but not skin, of transgenic mice. J Immunol 168(3):1001-1008

216. Luther SA, Lopez T, Bai W, Hanahan D, Cyster JG (2000) BLC expression in pancreatic islets causes B cell recruitment and lymphotoxin-dependent lymphoid neogenesis. Immunity 12:471-481

217. Kratz A, Campos-Neto A, Hanson MS, Ruddle NH (1996) Chronic inflammation caused by lymphotoxin is lymphoid neogenesis. J Exp Med 183:1461-1472

218. Sacca R, Cuff CA, Lesslauer W, Ruddle NH (1998) Differential activities of secreted lymphotoxin-alpha3 and membrane lymphotoxin-alpha1beta2 in lymphotoxin-induced inflammation: critical role of TNF receptor 1 signaling. J Immunol 160(1):485-491

219. Drayton DL, Ying X, Lee J, Lesslauer W, Ruddle NH (2003) Ectopic LT alpha beta directs lymphoid organ neogenesis with concomitant expression of peripheral node addressin and a HEVrestricted sulfotransferase. J Exp Med 197(9):1153-1163

220. Seleznik GM, Reding T, Romrig F, Saito Y, Mildner A, Segerer S, Sun LK, Regenass S, Lech M, Anders HJ, McHugh D, Kumagi T, Hiasa Y, Lackner C, Haybaeck J, Angst E, Perren A, Balmer ML, Slack E, MacPherson A, Manz MG, Weber A, Browning JL, Arkan MC, Rulicke T, Aguzzi A, Prinz M, Graf R, Heikenwalder M (2012) Lymphotoxin beta receptor signaling promotes development of autoimmune pancreatitis. Gastroenterology 143(5):1361-1374

221. Wanner-Seleznik GM, Reding T, Chen R, Gupta AK, Lenggenhager D, Browning J, Segerer S, Heikenwalder M, Graf R (2020) Amelioration of murine autoimmune pancreatitis by targeted LTbetaR inhibition and anti-CD20 treatment. Immunohorizons 4(11):688-700

222. Marinkovic T, Garin A, Yokota Y, Fu YX, Ruddle NH, Furtado GC, Lira SA (2006) Interaction of mature CD3+CD4+ T cells with dendritic cells triggers the development of tertiary lymphoid structures in the thyroid. J Clin Invest 116(10):2622-2632

223. Martin AP, Coronel EC, Sano G, Chen SC, Vassileva G, CanastoChibuque C, Sedgwick JD, Frenette PS, Lipp M, Furtado GC, Lira SA (2004) A novel model for lymphocytic infiltration of the thyroid gland generated by transgenic expression of the $\mathrm{CC}$ chemokine CCL21. J Immunol 173(8):4791-4798

224. Furtado GC, Marinkovic T, Martin AP, Garin A, Hoch B, Hubner W, Chen BK, Genden E, Skobe M, Lira SA (2007) Lymphotoxin beta receptor signaling is required for inflammatory lymphangiogenesis in the thyroid. Proc Natl Acad Sci USA 104(12):5026-5031

225. Motallebzadeh R, Rehakova S, Conlon TM, Win TS, Callaghan CJ, Goddard M, Bolton EM, Ruddle NH, Bradley JA, Pettigrew GJ (2011) Blocking lymphotoxin signaling abrogates the development of ectopic lymphoid tissue within cardiac allografts and inhibits effector antibody responses. Faseb J 26(1):51-62

226. Baddoura FK, Nasr IW, Wrobel B, Li Q, Ruddle NH, Lakkis FG (2005) Lymphoid neogenesis in murine cardiac allografts undergoing chronic rejection. Am J Transplant 5(3):510-516

227. Ruddle NH (1999) Lymphoid neo-organogenesis: lymphotoxin's role in inflammation and development. Immunol Res 19(2-3):119-125

228. Neyt K, Perros F, GeurtsvanKessel CH, Hammad H, Lambrecht BN (2012) Tertiary lymphoid organs in infection and autoimmunity. Trends Immunol 33(6):297-305 
229. Pitzalis C, Jones GW, Bombardieri M, Jones SA (2014) Ectopic lymphoid-like structures in infection, cancer and autoimmunity. Nat Rev Immunol 14(7):447-462

230. Schroder AE, Greiner A, Seyfert C, Berek C (1996) Differentiation of $\mathrm{B}$ cells in the nonlymphoid tissue of the synovial membrane of patients with rheumatoid arthritis. Proc Natl Acad Sci USA 93(1):221-225

231. Humby F, Bombardieri M, Manzo A, Kelly S, Blades MC, Kirkham B, Spencer J, Pitzalis C (2009) Ectopic lymphoid structures support ongoing production of class-switched autoantibodies in rheumatoid synovium. PLoS Med 6(1):e1

232. Bombardieri M, Barone F, Humby F, Kelly S, McGurk M, Morgan P, Challacombe S, De Vita S, Valesini G, Spencer J, Pitzalis C (2007) Activation-induced cytidine deaminase expression in follicular dendritic cell networks and interfollicular large B cells supports functionality of ectopic lymphoid neogenesis in autoimmune sialoadenitis and MALT lymphoma in Sjogren's syndrome. J Immunol 179(7):4929-4938

233. Mebius RE (2003) Organogenesis of lymphoid tissues. Nat Rev Immunol 3(4):292-303

234. Hemmerich S, Bistrup A, Singer MS, van Zante A, Lee JK, Tsay D, Peters M, Carminati JL, Brennan TJ, Carver-Moore K, Leviten M, Fuentes ME, Ruddle NH, Rosen SD (2001) Sulfation of L-selectin ligands by an HEV-restricted sulfotransferase regulates lymphocyte homing to lymph nodes. Immunity 15(2):237-247

235. Kobayashi M, Mitoma J, Nakamura N, Katsuyama T, Nakayama J, Fukuda M (2004) Induction of peripheral lymph node addressin in human gastric mucosa infected by Helicobacter pylori. Proc Natl Acad Sci USA 101(51):17807-17812

236. Kobayashi M, Mitoma J, Hoshino H, Yu SY, Shimojo Y, Suzawa K, Khoo KH, Fukuda M, Nakayama J (2011) Prominent expression of sialyl Lewis X-capped core 2-branched O-glycans on high endothelial venule-like vessels in gastric MALT lymphoma. J Pathol 224(1):67-77

237. Okamura T, Sakai Y, Hoshino H, Iwaya Y, Tanaka E, Kobayashi M (2015) Superficially located enlarged lymphoid follicles characterise nodular gastritis. Pathology 47(1):38-44

238. Canete JD, Santiago B, Cantaert T, Sanmarti R, Palacin A, Celis R, Graell E, Gil-Torregrosa B, Baeten D, Pablos JL (2007) Ectopic lymphoid neogenesis in psoriatic arthritis. Ann Rheum Dis 66(6):720-726

239. Abraham WM, Ahmed A, Sabater JR, Lauredo IT, Botvinnikova Y, Bjercke RJ, Hu X, Revelle BM, Kogan TP, Scott IL, Dixon RA, Yeh ET, Beck PJ (1999) Selectin blockade prevents antigen-induced late bronchial responses and airway hyperresponsiveness in allergic sheep. Am J Respir Crit Care Med 159(4 Pt 1):1205-1214

240. Tedder TF, Steeber DA, Pizcueta P (1995) L-selectin-deficient mice have impaired leukocyte recruitment into inflammatory sites. J Exp Med 181(6):2259-2264

241. Yang XD, Karin N, Tisch R, Steinman L, McDevitt HO (1993) Inhibition of insulitis and prevention of diabetes in nonobese diabetic mice by blocking L-selectin and very late antigen 4 adhesion receptors. Proc Natl Acad Sci USA 90(22):10494-10498

242. Bienkowska J, Allaire N, Thai A, Goyal J, Plavina T, Nirula A, Weaver M, Newman C, Petri M, Beckman E, Browning JL (2014) Lymphotoxin-LIGHT pathway regulates the interferon signature in rheumatoid arthritis. PLoS ONE 9(11):e112545

243. St Clair EW, Baer AN, Wei C, Noaiseh G, Parke A, Coca A, Utset TO, Genovese MC, Wallace DJ, McNamara J, Boyle K, KeyesElstein L, Browning JL, Franchimont N, Smith K, Guthridge JM, Sanz I, James JA (2018) Clinical efficacy and safety of baminercept, a lymphotoxin beta receptor fusion protein, in primary Sjogren's syndrome: results from a Phase II Randomized, Double-Blind, Placebo-Controlled Trial. Arthritis Rheumatol 70(9):1470-1480
244. Dogan A, Du M, Koulis A, Briskin MJ, Isaacson PG (1997) Expression of lymphocyte homing receptors and vascular addressins in low-grade gastric B-cell lymphomas of mucosaassociated lymphoid tissue. Am J Pathol 151(5):1361-1369

245. Lechleitner S, Kunstfeld R, Messeritsch-Fanta C, Wolff K, Petzelbauer P (1999) Peripheral lymph node addressins are expressed on skin endothelial cells. J Invest Dermatol 113(3):410-414

246. Avram G, Sanchez-Sendra B, Martin JM, Terradez L, Ramos D, Monteagudo C (2013) The density and type of MECA-79-positive high endothelial venules correlate with lymphocytic infiltration and tumour regression in primary cutaneous melanoma. Histopathology 63(6):852-61

247. Sebestyen T, Mohos A, Liszkay G, Somlai B, Gaudi I, Ladanyi A (2018) Correlation with lymphocyte infiltration, but lack of prognostic significance of MECA-79-positive high endothelial venules in primary malignant melanoma. Melanoma Res 28(4):304-310

248. Karpathiou G, Dumollard JM, Gavid M, Casteillo F, Vieville M, Prades JM, Froudarakis M, Peoc'h M (2021) High endothelial venules are present in pharyngeal and laryngeal carcinomas and they are associated with better prognosis. Pathol Res Pract 220:153392

249. Wirsing AM, Rikardsen OG, Steigen SE, Uhlin-Hansen L, Hadler-Olsen E (2016) Presence of tumour high-endothelial venules is an independent positive prognostic factor and stratifies patients with advanced-stage oral squamous cell carcinoma. Tumour Biol 37(2):2449-2459

250. Wirsing AM, Ervik IK, Seppola M, Uhlin-Hansen L, Steigen SE, Hadler-Olsen E (2018) Presence of high-endothelial venules correlates with a favorable immune microenvironment in oral squamous cell carcinoma. Mod Pathol 31(6):910-922

251. Hong SA, Hwang HW, Kim MK, Lee TJ, Yim K, Won HS, Sun S, Kim EY, Ko YH (2020) High endothelial venule with concomitant high CD8+ tumor-infiltrating lymphocytes is associated with a favorable prognosis in resected gastric cancer. J Clin Med 9(8):2628

252. Jiang L, Jung S, Zhao J, Kasinath V, Ichimura T, Joseph J, Fiorina P, Liss AS, Shah K, Annabi N, Joshi N, Akama TO, Bromberg JS, Kobayashi M, Uchimura K, Abdi R (2021) Simultaneous targeting of primary tumor, draining lymph node, and distant metastases through high endothelial venule-targeted delivery. Nano Today 36:101045

253. Martinet L, Filleron T, Le Guellec S, Rochaix P, Garrido I, Girard JP (2013) High endothelial venule blood vessels for tumor-infiltrating lymphocytes are associated with lymphotoxin beta-producing dendritic cells in human breast cancer. J Immunol 191(4):2001-2008

254. Song IH, Heo SH, Bang WS, Park HS, Park IA, Kim YA, Park SY, Roh J, Gong G, Lee HJ (2017) Predictive value of tertiary lymphoid structures assessed by high endothelial venule counts in the neoadjuvant setting of triple-negative breast cancer. Cancer Res Treat 49(2):399-407

255. Figenschau SL, Fismen S, Fenton KA, Fenton C, Mortensen ES (2015) Tertiary lymphoid structures are associated with higher tumor grade in primary operable breast cancer patients. BMC Cancer 15:101

256. Cipponi A, Mercier M, Seremet T, Baurain JF, Theate I, van den Oord J, Stas M, Boon T, Coulie PG, van Baren N (2012) Neogenesis of lymphoid structures and antibody responses occur in human melanoma metastases. Cancer Res 72(16):3997-4007

257. Avram G, Mixich F, Ioana M, Patrascu V, Monteagudo C (2014) Correlation between high endothelial vessels and histopathological features of different pigmented lesions. Curr Health Sci J 40(1):23-26

258. Bento DC, Jones E, Junaid S, Tull J, Williams GT, Godkin A, Ager A, Gallimore A (2015) High endothelial venules are rare 
in colorectal cancers but accumulate in extra-tumoral areas with disease progression. OncoImmunology 4(3):e974374

259. Di Caro G, Bergomas F, Grizzi F, Doni A, Bianchi P, Malesci A, Laghi L, Allavena P, Mantovani A, Marchesi F (2014) Occurrence of tertiary lymphoid tissue is associated with T-cell infiltration and predicts better prognosis in early-stage colorectal cancers. Clin Cancer Res 20(8):2147-2158

260. Pfuderer PL, Ballhausen A, Seidler F, Stark HJ, Grabe N, Frayling IM, Ager A, von Knebel DM, Kloor M, Ahadova A (2019) High endothelial venules are associated with microsatellite instability, hereditary background and immune evasion in colorectal cancer. Br J Cancer 121(5):395-404

261. Weinstein AM, Giraldo NA, Petitprez F, Julie C, Lacroix L, Peschaud F, Emile JF, Marisa L, Fridman WH, Storkus WJ, Sautes-Fridman C (2019) Association of IL-36gamma with tertiary lymphoid structures and inflammatory immune infiltrates in human colorectal cancer. Cancer Immunol Immunother 68(1):109-120

262. Silina K, Soltermann A, Attar FM, Casanova R, Uckeley ZM, Thut $\mathrm{H}$, Wandres M, Isajevs S, Cheng P, Curioni-Fontecedro A, Foukas P, Levesque MP, Moch H, Line A, van den Broek M (2018) Germinal centers determine the prognostic relevance of tertiary lymphoid structures and are impaired by corticosteroids in lung squamous cell carcinoma. Cancer Res 78(5):1308-1320

263. de Chaisemartin L, Goc J, Damotte D, Validire P, Magdeleinat P, Alifano M, Cremer I, Fridman WH, Sautes-Fridman C, Dieu-Nosjean MC (2011) Characterization of chemokines and adhesion molecules associated with $\mathrm{T}$ cell presence in tertiary lymphoid structures in human lung cancer. Cancer Res 71(20):6391-6399

264. Goc J, Germain C, Vo-Bourgais TK, Lupo A, Klein C, Knockaert S, de Chaisemartin L, Ouakrim H, Becht E, Alifano M, Validire P, Remark R, Hammond SA, Cremer I, Damotte D, Fridman WH, Sautes-Fridman C, Dieu-Nosjean MC (2014) Dendritic cells in tumor-associated tertiary lymphoid structures signal a Th1 cytotoxic immune contexture and license the positive prognostic value of infiltrating CD8+ T cells. Cancer Res 74(3):705-715

265. Remark R, Lupo A, Alifano M, Biton J, Ouakrim H, Stefani A, Cremer I, Goc J, Regnard JF, Dieu-Nosjean MC, Damotte D (2016) Immune contexture and histological response after neoadjuvant chemotherapy predict clinical outcome of lung cancer patients. OncoImmunology 5(12):e1255394

266. Goveia J, Rohlenova K, Taverna F, Treps L, Conradi L-C, Pircher A, Geldhof V, de Rooij LPMH, Kalucka J, Sokol L, GarcíaCaballero M, Zheng Y, Qian J, Teuwen L-A, Khan S, Boeckx B, Wauters E, Decaluwé H, De Leyn P, Vansteenkiste J, Weynand B, Sagaert X, Verbeken E, Wolthuis A, Topal B, Everaerts W, Bohnenberger H, Emmert A, Panovska D, De Smet F, Staal FJT, Mclaughlin RJ, Impens F, Lagani V, Vinckier S, Mazzone M, Schoonjans L, Dewerchin M, Eelen G, Karakach TK, Yang H, Wang J, Bolund L, Lin L, Thienpont B, Li X, Lambrechts D, Luo Y, Carmeliet P (2020) An integrated gene expression landscape profiling approach to identify lung tumor endothelial cell heterogeneity and angiogenic candidates. Cancer Cell 37(1):21-36.e13

267. Sakai Y, Hoshino H, Kitazawa R, Kobayashi M (2014) High endothelial venule-like vessels and lymphocyte recruitment in testicular seminoma. Andrology 2(2):282-289

268. Low S, Sakai Y, Hoshino H, Hirokawa M, Kawashima H, Higuchi K, Imamura Y, Kobayashi M (2016) High endothelial venulelike vessels and lymphocyte recruitment in diffuse sclerosing variant of papillary thyroid carcinoma. Pathology 48(7):666-674

269. Garcia-Hernandez ML, Uribe-Uribe NO, Espinosa-Gonzalez R, Kast WM, Khader SA, Rangel-Moreno J (2017) A unique cellular and molecular microenvironment is present in tertiary lymphoid organs of patients with spontaneous prostate cancer regression. Front Immunol 8:563
270. Koti M, Xu AS, Ren KYM, Visram K, Ren R, Berman DM, Siemens DR (2017) Tertiary lymphoid structures associate with tumour stage in urothelial bladder cancer. Bladder Cancer 3(4):259-267

271. Hennequin A, Derangere V, Boidot R, Apetoh L, Vincent J, Orry D, Fraisse J, Causeret S, Martin F, Arnould L, Beltjens F, Ghiringhelli F, Ladoire S (2016) Tumor infiltration by Tbet+ effector $\mathrm{T}$ cells and CD20+ B cells is associated with survival in gastric cancer patients. Oncoimmunology 5(2):e1054598

272. Sakimura C, Tanaka H, Okuno T, Hiramatsu S, Muguruma K, Hirakawa K, Wanibuchi H, Ohira M (2017) B cells in tertiary lymphoid structures are associated with favorable prognosis in gastric cancer. J Surg Res 215:74-82

273. Hiraoka N, Ino Y, Yamazaki-Itoh R, Kanai Y, Kosuge T, Shimada $\mathrm{K}$ (2015) Intratumoral tertiary lymphoid organ is a favourable prognosticator in patients with pancreatic cancer. Br J Cancer 112(11):1782-1790

274. Bahmani B, Uehara M, Ordikhani F, Li X, Jiang L, Banouni N, Ichimura T, Kasinath V, Eskandari SK, Annabi N, Bromberg JS, Shultz LD, Greiner DL, Abdi R (2018) Ectopic high endothelial venules in pancreatic ductal adenocarcinoma: a unique site for targeted delivery. EBioMedicine 38:79-88

275. Castino GF, Cortese N, Capretti G, Serio S, Di Caro G, Mineri R, Magrini E, Grizzi F, Cappello P, Novelli F, Spaggiari P, Roncalli M, Ridolfi C, Gavazzi F, Zerbi A, Allavena P, Marchesi F (2016) Spatial distribution of B cells predicts prognosis in human pancreatic adenocarcinoma. Oncoimmunology $5(4): \mathrm{e} 1085147$

276. Giraldo NA, Becht E, Pages F, Skliris G, Verkarre V, Vano Y, Mejean A, Saint-Aubert N, Lacroix L, Natario I, Lupo A, Alifano M, Damotte D, Cazes A, Triebel F, Freeman GJ, Dieu-Nosjean MC, Oudard S, Fridman WH, Sautes-Fridman C (2015) Orchestration and prognostic significance of immune checkpoints in the microenvironment of primary and metastatic renal cell cancer. Clin Cancer Res 21(13):3031-3040

277. Petitprez F, de Reynies A, Keung EZ, Chen TW, Sun CM, Calderaro J, Jeng YM, Hsiao LP, Lacroix L, Bougouin A, Moreira M, Lacroix G, Natario I, Adam J, Lucchesi C, Laizet YH, Toulmonde M, Burgess MA, Bolejack V, Reinke D, Wani KM, Wang WL, Lazar AJ, Roland CL, Wargo JA, Italiano A, Sautes-Fridman C, Tawbi HA, Fridman WH (2020) B cells are associated with survival and immunotherapy response in sarcoma. Nature 577(7791):556-560

278. Kroeger DR, Milne K, Nelson BH (2016) Tumor-infiltrating plasma cells are associated with tertiary lymphoid structures, cytolytic T-cell responses, and superior prognosis in ovarian cancer. Clin Cancer Res 22(12):3005-3015

279. Li Q, Liu X, Wang D, Wang Y, Lu H, Wen S, Fang J, Cheng B, Wang Z (2020) Prognostic value of tertiary lymphoid structure and tumour infiltrating lymphocytes in oral squamous cell carcinoma. Int J Oral Sci 12(1):24

280. Remark R, Alifano M, Cremer I, Lupo A, Dieu-Nosjean MC, Riquet M, Crozet L, Ouakrim H, Goc J, Cazes A, Flejou JF, Gibault L, Verkarre V, Regnard JF, Pages ON, Oudard S, Mlecnik B, Sautes-Fridman C, Fridman WH, Damotte D (2013) Characteristics and clinical impacts of the immune environments in colorectal and renal cell carcinoma lung metastases: influence of tumor origin. Clin Cancer Res 19(15):4079-4091

281. Pericart S, Syrykh C, Amara N, Franchet C, Malavaud B, Gaulard P, Girard JP, Ysebaert L, Laurent C, Brousset P (2020) Exclusive B-cell phenotype of primary prostatic lymphomas: a potential role of chronic prostatitis. Histopathology 76(5):767-773

282. Hindley JP, Jones E, Smart K, Bridgeman H, Lauder SN, Ondondo B, Cutting S, Ladell K, Wynn KK, Withers D, Price DA, Ager A, Godkin AJ, Gallimore AM (2012) T-cell trafficking facilitated by high endothelial venules is required for 
tumor control after regulatory T-cell depletion. Cancer Res 72(21):5473-5482

283. Schrama D, thor Straten P, Fischer WH, McLellan AD, Brocker EB, Reisfeld RA, Becker JC (2001) Targeting of lymphotoxinalpha to the tumor elicits an efficient immune response associated with induction of peripheral lymphoid-like tissue. Immunity 14(2):111-121

284. Schrama D, Voigt H, Eggert AO, Xiang R, Zhou H, Schumacher $\mathrm{TN}$, Andersen MH, thor Straten P, Reisfeld RA, Becker JC (2008) Immunological tumor destruction in a murine melanoma model by targeted LTalpha independent of secondary lymphoid tissue. Cancer Immunol Immunother 57(1):85-95

285. Ganss R, Hanahan D (1998) Tumor microenvironment can restrict the effectiveness of activated antitumor lymphocytes. Cancer Res 58(20):4673-4681

286. Peske JD, Thompson ED, Gemta L, Baylis RA, Fu YX, Engelhard VH (2015) Effector lymphocyte-induced lymph node-like vasculature enables naive T-cell entry into tumours and enhanced anti-tumour immunity. Nat Commun 6:7114

287. Allen E, Jabouille A, Rivera LB, Lodewijckx I, Missiaen R, Steri V, Feyen K, Tawney J, Hanahan D, Michael IP, Bergers G (2017) Combined antiangiogenic and anti-PD-L1 therapy stimulates tumor immunity through HEV formation. Sci Transl Med 9(385):eaak9679

288. Kabir AU, Subramanian M, Lee DH, Wang X, Krchma K, Wu J, Naismith T, Halabi CM, Kim JY, Pulous FE, Petrich BG, Kim S, Park HC, Hanson PI, Pan H, Wickline SA, Fremont DH, Park C, Choi K (2021) Dual role of endothelial Myct1 in tumor angiogenesis and tumor immunity. Sci Transl Med 13(583):eabb6731

289. Joshi NS, Akama-Garren EH, Lu Y, Lee DY, Chang GP, Li A, DuPage M, Tammela T, Kerper NR, Farago AF, Robbins R, Crowley DM, Bronson RT, Jacks T (2015) Regulatory T cells in tumor-associated tertiary lymphoid structures suppress antitumor T cell responses. Immunity 43(3):579-590

290. Finkin S, Yuan D, Stein I, Taniguchi K, Weber A, Unger K, Browning JL, Goossens N, Nakagawa S, Gunasekaran G, Schwartz ME, Kobayashi M, Kumada H, Berger M, Pappo O, Rajewsky K, Hoshida Y, Karin M, Heikenwalder M, Ben-Neriah Y, Pikarsky E (2015) Ectopic lymphoid structures function as microniches for tumor progenitor cells in hepatocellular carcinoma. Nat Immunol 16(12):1235-1244

291. Colbeck EJ, Jones E, Hindley JP, Smart K, Schulz R, Browne M, Cutting S, Williams A, Parry L, Godkin A, Ware CF, Ager A, Gallimore A (2017) Treg depletion licenses T cell-driven HEV neogenesis and promotes tumor destruction. Cancer Immunol Res 5(11):1005-1015

292. Shields JD, Kourtis IC, Tomei AA, Roberts JM, Swartz MA (2010) Induction of lymphoidlike stroma and immune escape by tumors that express the chemokine CCL21. Science 328(5979):749-752

293. Kim HJ, Kammertoens T, Janke M, Schmetzer O, Qin Z, Berek C, Blankenstein T (2004) Establishment of early lymphoid organ infrastructure in transplanted tumors mediated by local production of lymphotoxin alpha and in the combined absence of functional B and T cells. J Immunol 172(7):4037-4047

294. Johansson-Percival A, He B, Li ZJ, Kjellen A, Russell K, Li J, Larma I, Ganss R (2017) De novo induction of intratumoral lymphoid structures and vessel normalization enhances immunotherapy in resistant tumors. Nat Immunol 18(11):1207-1217

295. Liang J, Wang L, Wang C, Shen J, Su B, Marisetty AL, Fang D, Kassab C, Jeong KJ, Zhao W, Lu Y, Jain AK, Zhou Z, Liang H, Sun SC, Lu C, Xu ZX, Yu Q, Shao S, Chen X, Gao M, Claret FX, Ding Z, Chen J, Chen P, Barton MC, Peng G, Mills GB, Heimberger AB (2020) Verteporfin inhibits PD-L1 through autophagy and the STAT1-IRF1-TRIM28 signaling axis, exerting antitumor efficacy. Cancer Immunol Res 8(7):952-965
296. He B, Johansson-Percival A, Backhouse J, Li J, Lee GYF, Hamzah J, Ganss R (2020) Remodeling of metastatic vasculature reduces lung colonization and sensitizes overt metastases to immunotherapy. Cell Rep 30(3):714-724 e715

297. He B, Jabouille A, Steri V, Johansson-Percival A, Michael IP, Kotamraju VR, Junckerstorff R, Nowak AK, Hamzah J, Lee G, Bergers G, Ganss R (2018) Vascular targeting of LIGHT normalizes blood vessels in primary brain cancer and induces intratumoural high endothelial venules. J Pathol 245(2):209-221

298. Huang Y, Chen Y, Zhou S, Chen L, Wang J, Pei Y, Xu M, Feng J, Jiang T, Liang K, Liu S, Song Q, Jiang G, Gu X, Zhang Q, Gao X, Chen J (2020) Dual-mechanism based CTLs infiltration enhancement initiated by Nano-sapper potentiates immunotherapy against immune-excluded tumors. Nat Commun 11(1):622

299. Chelvanambi M, Fecek RJ, Taylor JL, Storkus WJ (2021) STING agonist-based treatment promotes vascular normalization and tertiary lymphoid structure formation in the therapeutic melanoma microenvironment. J Immunother Cancer 9(2):e001906

300. Weinstein AM, Chen L, Brzana EA, Patil PR, Taylor JL, Fabian KL, Wallace CT, Jones SD, Watkins SC, Lu B, Stroncek DF, Denning TL, Fu YX, Cohen PA, Storkus WJ (2017) Tbet and IL-36gamma cooperate in therapeutic DC-mediated promotion of ectopic lymphoid organogenesis in the tumor microenvironment. OncoImmunology 6(6): e1322238

301. Yu P, Lee Y, Liu W, Chin RK, Wang J, Wang Y, Schietinger A, Philip M, Schreiber H, Fu YX (2004) Priming of naive T cells inside tumors leads to eradication of established tumors. Nat Immunol 5(2):141-149

302. Thompson ED, Enriquez HL, Fu YX, Engelhard VH (2010) Tumor masses support naive $\mathrm{T}$ cell infiltration, activation, and differentiation into effectors. J Exp Med 207(8):1791-1804

303. Sautes-Fridman C, Petitprez F, Calderaro J, Fridman WH (2019) Tertiary lymphoid structures in the era of cancer immunotherapy. Nat Rev Cancer 19(6):307-325

304. Dieu-Nosjean MC, Goc J, Giraldo NA, Sautes-Fridman C, Fridman WH (2014) Tertiary lymphoid structures in cancer and beyond. Trends Immunol 35(11):571-580

305. Helmink BA, Reddy SM, Gao J, Zhang S, Basar R, Thakur R, Yizhak K, Sade-Feldman M, Blando J, Han G, Gopalakrishnan V, Xi Y, Zhao H, Amaria RN, Tawbi HA, Cogdill AP, Liu W, LeBleu VS, Kugeratski FG, Patel S, Davies MA, Hwu P, Lee JE, Gershenwald JE, Lucci A, Arora R, Woodman S, Keung EZ, Gaudreau PO, Reuben A, Spencer CN, Burton EM, Haydu LE, Lazar AJ, Zapassodi R, Hudgens CW, Ledesma DA, Ong S, Bailey M, Warren S, Rao D, Krijgsman O, Rozeman EA, Peeper D, Blank CU, Schumacher TN, Butterfield LH, Zelazowska MA, McBride KM, Kalluri R, Allison J, Petitprez F, Fridman WH, Sautes-Fridman C, Hacohen N, Rezvani K, Sharma P, Tetzlaff MT, Wang L, Wargo JA (2020) B cells and tertiary lymphoid structures promote immunotherapy response. Nature 577(7791):549-555

306. Ager A (2017) High endothelial venules and other blood vessels: critical regulators of lymphoid organ development and function. Front Immunol 8:45

307. Ager A, May MJ (2015) Understanding high endothelial venules: lessons for cancer immunology. OncoImmunology 4(6): 1008791

308. Colbeck EJ, Ager A, Gallimore A, Jones GW (2017) Tertiary lymphoid structures in cancer: drivers of antitumor immunity, immunosuppression, or bystander sentinels in disease? Front Immunol 8:1830

309. Engelhard VH, Rodriguez AB, Mauldin IS, Woods AN, Peske JD, Slingluff CL Jr (2018) Immune cell infiltration and tertiary lymphoid structures as determinants of antitumor immunity. $\mathbf{J}$ Immunol 200(2):432-442 
310. Rodriguez AB, Engelhard VH (2020) Insights into tumor-associated tertiary lymphoid structures: novel targets for antitumor immunity and cancer immunotherapy. Cancer Immunol Res 8(11):1338-1345

311. Liu X, Tsang JYS, Hlaing T, Hu J, Ni YB, Chan SK, Cheung SY, Tse GM (2017) Distinct tertiary lymphoid structure associations and their prognostic relevance in HER2 positive and negative breast cancers. Oncologist 22(11):1316-1324

312. Jansen CS, Prokhnevska N, Master VA, Sanda MG, Carlisle JW, Bilen MA, Cardenas M, Wilkinson S, Lake R, Sowalsky AG, Valanparambil RM, Hudson WH, McGuire D, Melnick K, Khan AI, Kim K, Chang YM, Kim A, Filson CP, Alemozaffar M, Osunkoya AO, Mullane P, Ellis C, Akondy R, Im SJ, Kamphorst AO, Reyes A, Liu Y, Kissick H (2019) An intra-tumoral niche maintains and differentiates stem-like CD8 T cells. Nature 576(7787):465-470

313. Martinet L, Girard JP (2013) Regulation of tumor-associated high-endothelial venules by dendritic cells: a new opportunity to promote lymphocyte infiltration into breast cancer? OncoImmunology 2(11):e26470

314. Adams TE, Alpert S, Hanahan D (1987) Non-tolerance and autoantibodies to a transgenic self antigen expressed in pancreatic beta cells. Nature 325(6101):223-228

315. Dunn GP, Bruce AT, Ikeda H, Old LJ, Schreiber RD (2002) Cancer immunoediting: from immunosurveillance to tumor escape. Nat Immunol 3(11):991-998

316. Dunn GP, Old LJ, Schreiber RD (2004) The three Es of cancer immunoediting. Annu Rev Immunol 22:329-360

317. Chen DS, Mellman I (2017) Elements of cancer immunity and the cancer-immune set point. Nature 541(7637):321-330

318. Ribas A, Wolchok JD (2018) Cancer immunotherapy using checkpoint blockade. Science 359(6382):1350-1355

319. Rosenberg SA, Restifo NP (2015) Adoptive cell transfer as personalized immunotherapy for human cancer. Science 348(6230):62-68

320. Sharma P, Allison JP (2015) The future of immune checkpoint therapy. Science 348(6230):56-61

321. Schumacher TN, Schreiber RD (2015) Neoantigens in cancer immunotherapy. Science 348(6230):69-74

322. Fridman WH, Pages F, Sautes-Fridman C, Galon J (2012) The immune contexture in human tumours: impact on clinical outcome. Nat Rev Cancer 12(4):298-306

323. Galon J, Costes A, Sanchez-Cabo F, Kirilovsky A, Mlecnik B, Lagorce-Pages C, Tosolini M, Camus M, Berger A, Wind P, Zinzindohoue F, Bruneval P, Cugnenc PH, Trajanoski Z, Fridman WH, Pages F (2006) Type, density, and location of immune cells within human colorectal tumors predict clinical outcome. Science 313(5795):1960-1964

324. Tumeh PC, Harview CL, Yearley JH, Shintaku IP, Taylor EJ, Robert L, Chmielowski B, Spasic M, Henry G, Ciobanu V, West AN, Carmona M, Kivork C, Seja E, Cherry G, Gutierrez AJ, Grogan TR, Mateus C, Tomasic G, Glaspy JA, Emerson RO, Robins H, Pierce RH, Elashoff DA, Robert C, Ribas A (2014) PD-1 blockade induces responses by inhibiting adaptive immune resistance. Nature 515(7528):568-571

325. Zhang L, Conejo-Garcia JR, Katsaros D, Gimotty PA, Massobrio M, Regnani G, Makrigiannakis A, Gray H, Schlienger K, Liebman MN, Rubin SC, Coukos G (2003) Intratumoral T cells, recurrence, and survival in epithelial ovarian cancer. N Engl J Med 348(3):203-213

326. Sade-Feldman M, Yizhak K, Bjorgaard SL, Ray JP, de Boer CG, Jenkins RW, Lieb DJ, Chen JH, Frederick DT, Barzily-Rokni M, Freeman SS, Reuben A, Hoover PJ, Villani AC, Ivanova E, Portell A, Lizotte PH, Aref AR, Eliane JP, Hammond MR, Vitzthum H, Blackmon SM, Li B, Gopalakrishnan V, Reddy SM, Cooper ZA, Paweletz CP, Barbie DA, Stemmer-Rachamimov A, Flaherty
KT, Wargo JA, Boland GM, Sullivan RJ, Getz G, Hacohen N (2018) Defining T cell states associated with response to checkpoint immunotherapy in melanoma. Cell 175(4):998-1013 e1020

327. Miller BC, Sen DR, Al Abosy R, Bi K, Virkud YV, LaFleur MW, Yates KB, Lako A, Felt K, Naik GS, Manos M, Gjini E, Kuchroo JR, Ishizuka JJ, Collier JL, Griffin GK, Maleri S, Comstock DE, Weiss SA, Brown FD, Panda A, Zimmer MD, Manguso RT, Hodi FS, Rodig SJ, Sharpe AH, Haining WN (2019) Subsets of exhausted CD8(+) T cells differentially mediate tumor control and respond to checkpoint blockade. Nat Immunol 20(3):326-336

328. Siddiqui I, Schaeuble K, Chennupati V, Fuertes Marraco SA, Calderon-Copete S, Pais Ferreira D, Carmona SJ, Scarpellino L, Gfeller D, Pradervand S, Luther SA, Speiser DE, Held W (2019) Intratumoral Tcf1(+)PD-1(+)CD8(+) T cells with stemlike properties promote tumor control in response to vaccination and checkpoint blockade immunotherapy. Immunity 50(1):195211 e110

329. Wu TD, Madireddi S, de Almeida PE, Banchereau R, Chen YJ, Chitre AS, Chiang EY, Iftikhar H, O'Gorman WE, Au-Yeung A, Takahashi C, Goldstein LD, Poon C, Keerthivasan S, de Almeida Nagata DE, Du X, Lee HM, Banta KL, Mariathasan S, Das Thakur M, Huseni MA, Ballinger M, Estay I, Caplazi P, Modrusan Z, Delamarre L, Mellman I, Bourgon R, Grogan JL (2020) Peripheral T cell expansion predicts tumour infiltration and clinical response. Nature 579(7798):274-278

330. Yost KE, Satpathy AT, Wells DK, Qi Y, Wang C, Kageyama R, McNamara KL, Granja JM, Sarin KY, Brown RA, Gupta RK, Curtis C, Bucktrout SL, Davis MM, Chang ALS, Chang HY (2019) Clonal replacement of tumor-specific T cells following PD-1 blockade. Nat Med 25(8):1251-1259

331. Tang H, Wang Y, Chlewicki LK, Zhang Y, Guo J, Liang W, Wang J, Wang X, Fu YX (2016) Facilitating T cell infiltration in tumor microenvironment overcomes resistance to PD-L1 blockade. Cancer Cell 29(3):285-296

332. Yu P, Fu YX (2008) Targeting tumors with LIGHT to generate metastasis-clearing immunity. Cytokine Growth Factor Rev 19(3-4):285-294

333. Newick K, O'Brien S, Moon E, Albelda SM (2017) CAR T cell therapy for solid tumors. Annu Rev Med 68:139-152

334. Krishna S, Lowery FJ, Copeland AR, Bahadiroglu E, Mukherjee R, Jia L, Anibal JT, Sachs A, Adebola SO, Gurusamy D, Yu Z, Hill V, Gartner JJ, Li YF, Parkhurst M, Paria B, Kvistborg P, Kelly MC, Goff SL, Altan-Bonnet G, Robbins PF, Rosenberg SA (2020) Stem-like CD8 T cells mediate response of adoptive cell immunotherapy against human cancer. Science 370(6522):1328-1334

335. Gattinoni L, Zhong XS, Palmer DC, Ji Y, Hinrichs CS, Yu Z, Wrzesinski C, Boni A, Cassard L, Garvin LM, Paulos CM, Muranski P, Restifo NP (2009) Wnt signaling arrests effector T cell differentiation and generates CD8+ memory stem cells. Nat Med 15(7):808-813

336. Hinrichs CS, Spolski R, Paulos CM, Gattinoni L, Kerstann KW, Palmer DC, Klebanoff CA, Rosenberg SA, Leonard WJ, Restifo NP (2008) IL-2 and IL-21 confer opposing differentiation programs to CD8+ T cells for adoptive immunotherapy. Blood 111(11):5326-5333

337. Klebanoff CA, Gattinoni L, Torabi-Parizi P, Kerstann K, Cardones AR, Finkelstein SE, Palmer DC, Antony PA, Hwang ST, Rosenberg SA, Waldmann TA, Restifo NP (2005) Central memory self/tumor-reactive $\mathrm{CD} 8+\mathrm{T}$ cells confer superior antitumor immunity compared with effector memory T cells. Proc Natl Acad Sci USA 102(27):9571-9576

338. Cabrita R, Lauss M, Sanna A, Donia M, Skaarup Larsen M, Mitra S, Johansson I, Phung B, Harbst K, Vallon-Christersson J, van Schoiack A, Lovgren K, Warren S, Jirstrom K, Olsson H, 
Pietras K, Ingvar C, Isaksson K, Schadendorf D, Schmidt H, Bastholt L, Carneiro A, Wargo JA, Svane IM, Jonsson G (2020) Tertiary lymphoid structures improve immunotherapy and survival in melanoma. Nature 577(7791):561-565

339. Michot JM, Bigenwald C, Champiat S, Collins M, Carbonnel F, Postel-Vinay S, Berdelou A, Varga A, Bahleda R, Hollebecque A, Massard C, Fuerea A, Ribrag V, Gazzah A, Armand JP, Amellal N, Angevin E, Noel N, Boutros C, Mateus C, Robert C, Soria JC, Marabelle A, Lambotte O (2016) Immune-related adverse events with immune checkpoint blockade: a comprehensive review. Eur J Cancer 54:139-148

Publisher's Note Springer Nature remains neutral with regard to jurisdictional claims in published maps and institutional affiliations. 